\title{
WestVirginiaUniversity
}

THE RESEARCH REPOSITORY @ WVU

Graduate Theses, Dissertations, and Problem Reports

2013

\section{Evaluating Biodegradable Containers as Alternatives to Plastic Pots}

Renee L. Conneway

West Virginia University

Follow this and additional works at: https://researchrepository.wvu.edu/etd

\section{Recommended Citation}

Conneway, Renee L., "Evaluating Biodegradable Containers as Alternatives to Plastic Pots" (2013). Graduate Theses, Dissertations, and Problem Reports. 541.

https://researchrepository.wvu.edu/etd/541

This Thesis is protected by copyright and/or related rights. It has been brought to you by the The Research Repository @WVU with permission from the rights-holder(s). You are free to use this Thesis in any way that is permitted by the copyright and related rights legislation that applies to your use. For other uses you must obtain permission from the rights-holder(s) directly, unless additional rights are indicated by a Creative Commons license in the record and/ or on the work itself. This Thesis has been accepted for inclusion in WVU Graduate Theses, Dissertations, and Problem Reports collection by an authorized administrator of The Research Repository @ WVU. For more information, please contact researchrepository@mail.wvu.edu. 
Evaluating Biodegradable Containers as Alternatives to Plastic Pots

\author{
Renee L. Conneway
}

Thesis submitted to the Davis College of Agriculture, Natural Resources, and Design at West Virginia University in partial fulfillment of the requirements for the degree of

Master of Science in

Horticulture

\author{
Sven Verlinden, Ph.D., Chair \\ Nicole Waterland, Ph.D. \\ James Kotcon, Ph.D.
}

Division of Plant and Soil Sciences

Morgantown, West Virginia

2013

Keywords: Sustainability, Horticulture, Greenhouse Production, Container Growing, Biopots. 


\section{ABSTRACT \\ Evaluating Biodegradable Containers as Alternatives to Plastic Pots}

\section{Renee L. Conneway}

Marked improvements in the sustainability of the horticulture industry have occurred over the last few decades. Movement towards better management practices in areas such as pesticide (IPM), fertilizer application and water usage characterizes today's industry. However, several obstacles have to be overcome for true long-term sustainability of the ornamental horticulture industry. One of these obstacles is the abundant use of plastics in the horticulture industry. This research focused on reducing the industry's plastic waste stream by evaluating the effects of biodegradable pots on plant growth parameters and substrate chemistry, as well as characteristics of biodegradable pots such as strength and algal/fungal growth. Plastic pots have become an industry standard, but do have two important limitations. The container walls are impermeable; therefore when the roots contact the surface, they tend to circle the container. Circling of roots in turn results in poor landscape establishment. The other limitation to plastic is the issue of proper disposal. While plastics represent only $7 \%$ of the waste stream by weight, they take up $20 \%$ of the waste stream by volume. Recycling of horticultural products such as plastic containers is further complicated by contamination, such as dirt residue, grease, vegetation, moisture, pesticide contamination, and ultraviolet light degradation. In 2009, the EPA found that nationwide, only $7.1 \%$ of 29 million tons of plastic was recycled. An alternative to plastic pots is biodegradable pots. Biopots are defined as pots not made from petroleum, that degrade rapidly. Despite their potential as a sustainable alternative to plastic pots, recent studies focusing on the water use of biopots have found that some biodegradable containers require more frequent irrigation and can be significantly weaker than plastic pots, especially when wet. We investigated plant growth, watering frequency, pot strength, pot algal growth, denesting times, and percent degradation of biodegradable pots. Few differences were observed in plant growth. Wood fiber, peat, and manure pots showed lower pot strength, higher amounts of algal growth, and required a higher watering frequency compared to the control plastic pot in all trials. Peat pots required significantly more time to denest, and manure pots showed higher degradation in the field compared to all other pots. All pots studied were capable of producing a marketable plant. These results suggest that biodegradable pots do show potential as replacements for plastic pots, but factors such as pot strength, algal growth, and ease of denesting will be important to their adoption by the industry. 


\section{Acknowledgments}

I owe gratitude to many people who were instrumental in helping me complete this project. I give a huge thank you to Dr. Sven Verlinden for supporting me throughout my undergraduate years, encouraging me to become a McNair Scholar, writing countless recommendations, and for being a supportive listener during some challenging times. But, most of all, I credit Dr. Verlinden with being the sole person to convince me to become a graduate student! Thank you for choosing me for this project, and for helping me every step of the way. I'm grateful for my committee members, Dr. Nicole Waterland and Dr. James Kotcon. Thank you both for always having the time to answer my questions and for supporting me throughout my research.

I am thankful for all the student workers, greenhouse staff, and friends that put in countless hours assisting with my research. Thanks to Lauren Hutzell, Whitney Garton, Alisha Shiffer, Bev Schell, Gerardo Aguilera, Sue Myers, Allen Davis, and Milly Mullins. Additional thanks to my girlfriend, Kayla Show, for providing much needed encouragement throughout the thesis writing process, and listening with the utmost attention as I practiced my defense countless times. I would also like to show appreciation to Amber Hines, Denny Smith, and Dan Robison for their encouraging words, and allowing me to take the much needed time to finish my thesis and defense. 


\section{Table of Contents}

Abstract
Acknowledgments
List of Tables
List of Figures
Chapter 1 - Introduction and Literature Review
History of the Industry
Insect and Weed Control
Fertilizers
Irrigation
Traditional Containers
Biodegradable Containers
Overview and Goal
Objectives
Chapter 2 - Evaluating the Potential Use of Biopots for Greenhouse Production
Summary
Background
Materials and Methods
Plant Growth Results
Substrate Results
Watering Frequency
Algal Growth




\section{List of Tables}

Table 2.1 Container types and manufacturers of pots used in this experiment

Table 2.2 Final plant growth of Impatiens spp. 'Sunpatiens Compact' grown in a a greenhouse for five weeks in 2011 using biodegradable pots

Table 2.3 Final plant growth of Lavendula angustifolia 'Elegans Ice' grown in a greenhouse for ten weeks in 2011 using biodegradable pots.

Table 2.4 Final plant growth of Impatiens spp. 'Sunpatiens Compact' grown in a greenhouse for six weeks in 2012 using biodegradable pots.

Table 2.5 Final plant growth of Lavendula angustifolia 'Elegans Ice' grown in a greenhouse for twelve weeks in 2012 using biodegradable pots

Table 2.6 Leachate $\mathrm{pH}$ of media in biodegradable pots used to grow Impatiens spp.

'Sunpatiens Compact' in 2011.

Table 2.7 Leachate $\mathrm{pH}$ of media in biodegradable pots used to grow Lavendula angustifolia 'Elegans Ice' in 2011

Table 2.8 Leachate $\mathrm{pH}$ of media in biodegradable pots used to grow Impatiens spp.

'Sunpatiens Compact' in 2012.

Table 2.9 Leachate $\mathrm{pH}$ of media in biodegradable pots used to grow Lavendula angustifolia 'Elegans Ice' in 2012.

Table 2.10 Leachate EC $(\mathrm{mS} / \mathrm{cm})$ of media in biodegradable pots used to grow

Impatiens spp. 'Sunpatiens Compact' in 2011

Table 2.11 Leachate EC $(\mathrm{mS} / \mathrm{cm})$ of media in biodegradable pots used to grow

Lavendula angustifolia 'Elegans Ice' in 2011

Table 2.12 Leachate EC $(\mathrm{mS} / \mathrm{cm})$ of media in biodegradable pots used to grow Impatiens spp. 'Sunpatiens Compact' in 2012

Table 2.13 Leachate EC $(\mathrm{mS} / \mathrm{cm})$ of media in biodegradable pots used to grow Lavendula angustifolia 'Elegans Ice' in 2012

Table 2.14 Pot characteristics of biodegradable containers used to grow Impatiens spp. 'Sunpatiens Compact' in 2011

Table 2.15 Pot characteristics of biodegradable containers used to grow Lavendula angustifolia 'Elegans Ice' in 2011

Table 2.16 Pot characteristics of biodegradable containers used to grow Impatiens spp.

'Sunpatiens Compact' in 2012

Table 2.17 Pot characteristics of biodegradable containers used to grow Lavendula angustifolia 'Elegans Ice' in 2012 65

Table 3.1 Container types and manufacturers of pots used in this experiment 83

Table 3.2 Final plant growth of Lantana camara 'Luscious Citrus' and pot degradation of biopots after one growing season (15 weeks) in the landscape in 2011 84 


\section{List of Tables}

Table 3.3 Final plant growth of Cleome hassleriana 'Seniorita Rosalita' and pot degradation of biopots after one growing season (15 weeks) in the landscape in 2011

Table 3.4 Final plant growth of Impatiens spp. 'Sunpatiens Compact' and pot degradation of biopots after one growing season (15 weeks) in the landscape in 2011

Table 3.5 Final plant growth of Lantana camara 'Luscious Citrus' and pot degradation of biopots after one growing season (15 weeks) in the landscape in 2012

Table 3.6 Final plant growth of Cleome hassleriana 'Seniorita Rosalita' and pot degradation of biopots after one growing season (15 weeks) in the landscape in 2012

Table 3.7 Final plant growth of Impatiens spp. 'Sunpatiens Compact' and pot degradation of biopots after one growing season (15 weeks) in the landscape in 2012

Table 4.1 Average denesting time required for biodegradable pots 93 


\section{List of Figures}

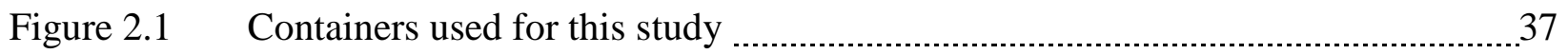

Figure 2.2 Experimental design of the greenhouse experiment _......................................39

Figure 2.3 Photographs depicting visual ratings of Lavendula angustifolia

'Elegans Ice' in 2011

Figure 2.4 Leachate $\mathrm{pH}$ of media in biodegradable pots used to grow Impatiens spp.

'Sunpatiens Compact' in 2011 50

Figure 2.5 Leachate $\mathrm{pH}$ of media in biodegradable pots used to grow Lavendula angustifolia 'Elegans Ice' in 2011

Figure 2.6 Leachate $\mathrm{pH}$ of media in biodegradable pots used to grow Impatiens spp.

Sunpatiens Compact' in 2012 52

Figure 2.7 Leachate $\mathrm{pH}$ of media in biodegradable pots used to grow Lavendula angustifolia 'Elegans Ice' in 2012

Figure 2.8 Leachate EC of media in biodegradable pots used to grow Impatiens spp. 'Sunpatiens Compact' in 2011 58

Figure 2.9 Leachate EC of media in biodegradable pots used to grow Lavendula angustifolia 'Elegans Ice' in 2011

Figure 2.10 Leachate EC of media in biodegradable pots used to grow Impatiens spp. 'Sunpatiens Compact' in 2012 60

Figure 2.11 Leachate EC of media in biodegradable pots used to grow Lavendula angustifolia 'Elegans Ice' in 2012

Figure 3.1 Monthly mean temperatures at the Morgantown, WV site for the 2011 and 2012 growing seasons

Figure 3.2 Monthly mean precipitation at the Morgantown, WV site for the 2011 and 2012 growing seasons 82 


\section{Chapter 1: Introduction and Literature Review}

As consumers exhibit more environmental awareness, industries are pushed to make their products environmentally friendly and sustainable. Sustainability can be broadly defined as meeting the needs of the present without compromising the needs of the future (Spiertz, 2008). There are several factors that contribute to the sustainability of the horticulture industry, including effective insect control, fertilization, water usage, planting media, container selection, plant selection, and plastic recycling programs. Great strides have been made in the last few decades to improve the sustainability of the horticulture industry, including the adoption of Integrated Pest Management (IPM), the use of slow release fertilizers, and drip irrigation. Despite these improvements several obstacles still need to be overcome for true sustainability. In order to fully understand the improvements that have been made over the last fifty years, it is important to understand the history of the industry and the changes that have occurred.

\section{History of the Industry}

The early history of the horticulture industry began with the first settlers of the Massachusetts Bay Colony in 1630 (Davidson et al., 2000). Records show that settlers not only planted fruit trees for their own benefit, but also grew fruit trees to trade (Davidson et al., 2000). Nearly a century later, in 1720 , the first greenhouse with glass on all sides was built by Bostonian Andrew Faneuil, and records show that he used it to grow fruit. In 1737, Linnaean Botanical Gardens, also referred to as Prince Nursery, was begun by the Prince family in Flushing, New York, and is considered the first commercial nursery in North America (Higginbotham, 1990). The nursery produced grafted apple, pear, and cherry trees that stocked most orchards in the surrounding areas. The outbreak of the American Revolution slowed the growth of the Horticulture industry significantly. Both sides however viewed Prince Nursery as 
important, and the facility was spared and even protected at times. Still, the war negatively impacted the demand for products, and the nursery had to sell over 10,000 cherry trees for barrel making (Higginbotham, 1990). After the war, other nurseries began to develop in both New York and New Jersey, and several more greenhouses were built in the Boston area. Most products were sold locally due to limited transportation, but the completion of the Erie Canal in 1824 helped to spur growth of the Horticulture industry by providing easy transportation to the Western frontier (Higginbotham, 1990).

By 1850, New York had become the nursery center of the nation, and Boston the center of greenhouse vegetable production (Davidson et al., 2000). The industry continued to grow until demand was again dampened, this time due to the Civil War. After the war ended, demand increased, and the country saw a time of development and the expansion of the railroad system. By 1869 , the railroad allowed plant stock to be transported long distances, and led to the start of many new businesses (Davidson et al., 2000; Higginbotham, 1990). In addition, the federal government mandated in 1873 that new prairie homes should have 40 acres of timber trees, thus boosting the demand for nursery stock (Higginbotham, 1990).

Key organizations were formed that would help the industry to further grow and promote best management practices. The American Association of Nurserymen (AAN) was created in 1876, and the American Society for Horticultural Science in 1903 (Janick, 2007). Up to this point, the industry had seen many boom and bust cycles. Many nurseries would overproduce stock and undercut other businesses, thus driving prices down, until a drought or bad winter reduced the surplus and the market again stabilized. The AAN was essential during this time in encouraging growers to manage professionally, adhere to profitable pricing strategies, and also 
lobbied the railroad for lower freight rates, all of which resulted in a stabilization of the industry by the early 1900's (Higginbotham, 1990).

The early 1900's were marked by the introduction of detrimental diseases to the industry, such as peach yellows, white pine blister rust, and chestnut blight (Higginbotham, 1990). To combat this, the government passed the first national Plant Quarantine Act in 1912, which prohibited certain plants from being imported into the country (Davidson et al., 2000). Seven years later, Quarantine 37 was instituted, and severely restricted an even larger list of essential plants from entering the country (Higginbotham, 1990; Davidson et al., 2000). These bans increased the demand for US seedlings and stock, and coupled with the Parcel Post Act of 1912, the industry experienced a temporary boom. Retail outlets were created, mail order companies were started, and technical innovations, such as tractors, were adopted (Higginbotham, 1990; Davidson et al., 2000).

The stock market crash and subsequent depression caused prices to fall and demand to drop, but a garden club movement of the 1930's introduced landscaping and ornamentals to the middle class. The industry began a slow switch from fruit tree production to its current day ornamental plant production (Davidson et al., 2000).

Major changes to the industry occurred with World War II. The war caused a lack of labor, and the industry began experimenting with alternative workers such as prisoners, Mexican immigrants, teenagers, and women (Higginbotham, 1990). After the war, the housing market boomed, and the demand again escalated, pushing the growing/production process to become more streamlined and efficient (Chappell, 2012). This new approach in growing led to the eventual adoption of insecticidal and herbicidal controls, inorganic fertilization regimes, 
mechanical innovations, advancements in both technology and transportation, and the introduction of container growing.

\section{Insect and Weed Control}

Various forms of pesticides have been in use since the beginning of agriculture. The Romans were known to use sulfur to combat insects and salt to control weeds (Bohmont, 1983; National Research Council, 2000). In the United States, insect control mainly depended on picking or washing off the insects until the mid-1800's, when botanicals like pyrethrum became available. Research on the structure and synthesis of botanical insecticides began in the 1920's, and by the 1930's the discovery of synthetic organic insecticides had become a major scientific goal (Casida and Quistand, 1998). In 1939, Paul Muller discovered the insecticidal properties of dichlorodiphenyl trichloroethane, now known as DDT (Carson, 1962; Ignacimuthu and Jayaraj, 2005; National Research Council, 2000). Soon after the discovery of DDT, hundreds of synthetic pesticides and herbicides became available on the market during and after World War II (Bohmont, 1983). World War II fostered an era of acceptance for these newfound chemical controls, as immediate remedies were needed during wartime and the cultural and biological control methods of the time required patience and adaptability (McWilliams, 2008). DDT especially was held in high esteem, mostly for its broad spectrum activity against insect pests of agriculture and human health (Delaplane, 1996). One magazine article printed in 1945 even regarded DDT as the “...war's greatest contribution to the future health of the world” (Simmons, 1945).

During this time, pesticides were considered to pose little long term environmental dangers. Fish kills during the 1940-50's were regarded as either "misuse or unavoidable side effects of pest control" (Casida and Quistand, 1998). The dangers of using DDT and other broad 
spectrum pesticides became apparent in the 1960-1970's with increasing insect resistance, unintended devastation of natural enemies, and surging secondary pests (National Research Council, 2000). In 1962, the book "Silent Spring" by Rachel Carson fueled public concern and caused the word "pesticide" to become stigmatized (Casida and Quistand, 1998; Higginbotham, 1990). The Environmental Protection Agency (EPA) was created in 1970, and in 1973, cancelled the registration for DDT and it was promptly removed from the market (Mullen et al., 2005; Higginbotham, 1990).

The overuse of broad spectrum pesticides and subsequent consequences spawned the development and implementation of Integrated Pest Management (IPM) (Delaplane, 1996). The framework for the development of IPM comes from the 1959 article entitled "The Integrated Control Concept" by Stern et, al. (1959). Up to this point, there had been no universal threshold levels established to determine when appropriate controls should be applied. Stern et al., (1959) used the Economic Injury Level (EIL) and the Economic Threshold (ET) to "develop constructs for sensible integration of chemical and biological controls." Other improvements included enhanced selective toxicity of chemicals, a more careful study of the environmental impacts, and a shift from persistent to degradable substances (Casida and Quistand, 1998). By the end of the 1980's, IPM was seen as a potential method to reduce the use of chemicals (Davidson et al., 2000). Modern day IPM integrates cultural, biological, and chemical controls by using various concepts, such as identifying economic thresholds, utilizing natural enemies, and using selective pesticides when necessary (Mullen et al., 2005). A clear movement towards judicious application of pesticides and herbicides is now apparent in the ornamental horticulture industry of the $21^{\text {st }}$ century. 


\section{Fertilizers}

Much like pesticides, natural organic fertilizers have also been in use since the beginning of agriculture about 10,000 years ago. Early Neolithic farmers cultivated their fields repeatedly, thus depleting the nutrients, but once they learned to keep cattle and sheep, they began enriching the soil with manure (McNeill and Winiwarter, 2004). The need for additional fertilization did not come about until the growth of urban life over the past 5000 years. With the growth of urbanization, produce was shipped from fields to cities, and subsequently, nutrients were transported off the farm, and inevitably wind up in the waste stream to the ocean (McNeill and Winiwarter, 2004). Population growth in the mid- $18^{\text {th }}$ century put pressures on the food supplies that led to new theories about soil fertilization, such as Justus von Liebig's idea that nitrogen, phosphorus, and potassium are required for plant growth (McNeill and Winiwarter, 2004). Beginning in the 1830's, demand for nutrients was very high. Horse manure was shipped by boat to New York City, as well as guano from Chile and Peru, rock phosphate, superphosphate, fishmeal, and potash (Mikkelsen and Bruulsema, 2005). The Morrill Act of 1862, which established land grant colleges, and the Hatch Act of 1887 that provided research facilities, led to many rapid advances in fertilizer research.

Undoubtedly, the biggest breakthrough to occur in the fertiliizer industry was the work of Fritz Haber and Carl Bosch. Haber and Bosch found a way to synthesize ammonia from the air, thus making nitrogenous fertilizer a fairly cheap commodity (McNeill and Winiwarter, 2004). At first, most of the new $\mathrm{NH}_{3}$ was used for explosives during World War I (Mikkelsen and Bruulsema, 2005). It was not until the 1950's that inorganic nitrogenous fertilizer gained popularity. Today, inorganic fertilizer is the top choice for fertility improvements in ornamental horticulture. Inorganic fertilizers are most commonly applied either by a slow-release granular 
application, or a continuous liquid feed, sometimes referred to as fertigation (Poincelot, 2004).

Slow release application reduces the frequency of application, but is more expensive. Therefore, fertigation is more commonly used, especially in the greenhouse setting. Inorganic fertilizer is relatively inexpensive when compared to its impact on increasing the yield of field crops, and has therefore often been misused and over-applied (Goulding et al., 2008).

This has resulted in environmental concerns, particularly concerning non-point source pollution of surface and ground water. These environmental concerns have led to a recent interest in returning to earlier fertilization practices, such as an improved utilization of animal manures, the use of recycled municipal products, application of compost, and cover cropping (Mikkelsen and Bruulsema, 2005). Similar to the IPM method that has been developed for pest control, Best Management Practices (BMPs) are slowly being developed for nutrient control. BMPs can include structural, vegetative, or cultural methods (Veith, 2002).

\section{Irrigation}

The history of irrigation parallels that of agriculture itself. Many of the early civilizations around the world were known to use surface irrigation (Fereres et al., 2003). With this type of irrigation, the water is uncontrolled, and moves by gravity. Though it is not particularly efficient, this method was used for thousands of years, and is still greatly used around the world today (Fereres et al., 2003). In the U.S. however, population growth and subsequent increased demand for food have resulted in a greater need for irrigation. Today, water usage has become a great concern for the horticulture industry, especially in states such as California, North Carolina, Florida, Oregon, and Texas, where laws and regulations limit water consumption (Beeson et al., 2004). In some areas of Florida, regulations over the past 12 years have decreased water usage allotment by as much as $40 \%$ (Beeson et al., 2004). This trend will undoubtedly extend to states 
other than the ones mentioned above in the future. These changes have driven the horticulture industry to begin to use water conserving irrigation, especially in states with limited water sources or access to water sources.

Greenhouses have made comparatively greater strides in reducing water usage than nurseries. Although overhead spray irrigation is still a common irrigation practice, more modern systems such as trickle or drip irrigation and subirrigation are routinely used in the greenhouse setting and have the potential to significantly reduce water use in this branch of ornamental horticulture (Poincelot, 2004). Trickle (drip) irrigation supplies water directly to the soil media via small emitters at a slow rate (Poincelot, 2004). Trickle irrigation allows the media adequate time to absorb water, making it a very effective system, with nearly $90 \%$ water use efficiency (Poincelot, 2004).

Nursery operations currently have several irrigation options, including overhead sprinklers, trickle and spray irrigation, and spray stakes or emitters. Overhead sprinklers are the most common system used for irrigating containers less than 5 gallons (Davidson et al., 2000). However, depending on the size and placement of containers, as much as $80 \%$ of water applied can be lost (Davidson et al., 2000; Beeson, 2006). Modern day irrigation practices have begun to reduce runoff and water overuse by increasing efficiency and reducing the number of irrigation applications (Beeson et al., 2004). In nurseries, this has been accomplished by optimizing plant spacing, precision spray nozzles, and reducing applications by monitoring plant water use. One way this has been accomplished is by applying irrigation based on plant demand, otherwise known as the Daily Water Usage (DWU), which is the combined loss of water from substrate evaporation and plant transpiration (Warsaw et al., 2009). One common way to determine DWU is by using soil moisture sensors that record the water lost over a known interval of time 
(Warsaw et al., 2009). The DWU is calculated and water is applied to replenish the lost water. A current drawback to using this type of irrigation is that the DWU of a plant must be known or determined (Warsaw et al., 2009). Complexity, accuracy, and cost all currently limit the use of DWU on a routine basis (S. Verlinden, personal communication). With no additional sources of water available, and having reached the peak of irrigation application efficiency with current technology, it seems likely that the industry will move towards using soil sensors and DWU for future irrigation systems.

\section{Containers}

One of the most significant changes to the industry was the introduction of containers for growing purposes. Prior to this period, plants were grown in the ground and balled-andburlapped for transportation and sale. The introduction of containers in the 1950's streamlined the growing process, allowed for automation, prolonged plant life, and allowed growers to use land that was otherwise unsuitable for production (Chappell, 2012). Coupled with the development of the National Highway system, shipping of horticultural products became much easier and led to further expansion of the industry. At first, clay containers were used, but soon these were found to be too heavy and were easily broken. The industry then moved towards using recycled restaurant food cans. The downsides to these food cans though were sharp edges and potential rusting (Chappell, 2012; Higginbotham, 1990). Soon, custom metal containers that could be easily stacked and stored and that were coated with rust resistant paint became available to the industry.

In the 1960's, plastic pots were introduced and quickly became an economical and industry standard that still exists today. These petroleum-based plastic containers have become the packaging of choice because of their durability, and their flexibility to be made into virtually 
any size, shape, or color (Evans et al., 2010). Plastic containers are easily stacked and stored, and can withstand greenhouse automation, transportation, and marketing. Plants grown in plastic containers are typically easy to remove from the pot, and still look aesthetically pleasing once purchased by the consumer (Evans and Hensley, 2004).

Plastic containers, however, have two significant limitations. The container walls are impermeable, so when the roots contact the surface, they tend to circle the container (Evans and Karcher, 2004). Root circling can be detrimental to a plant for numerous reasons, including girdling of the stem, failing to adequately anchor plants once planted, restricting the uptake of water, and decreasing nutrient absorption (Appleton, 1989). The other limitation to plastic is the issue of proper disposal (Evans and Karcher, 2004). In 1993, Garthe and Kowal found that of the 542 million pounds of plastic used in agriculture annually, 320 million pounds, or 59\%, was attributed to plant containers (Garthe and Kowal, 1993). While agricultural plastic only contributes about $1 \%$ to the total plastic waste stream in the US, the amount of waste is still significant and could be improved upon (Garthe and Kowal, 1993; EPA, 2010).

Two solutions to reduce plastic waste have been proposed, but both have limitations in the agriculture industry. One solution is to reuse plastic containers within the greenhouse and nursery setting, but the cost of cleaning and sterilizing often hinders this process. An additional obstacle to this solution is that containers are typically are taken home and disposed of by the consumer, and are often not returned to the greenhouse.

The second solution to reducing plastic waste is recycling. Recycling not only reduces waste, but by reusing the materials collected, it is possible to cut down on energy and fossil fuel consumption. Recycling programs have grown considerably over the last ten years, and for certain products, the recycling rates are higher. For instance, in 2009, the buyback battery 
program netted a $95.7 \%$ recycling rate for car batteries, and similar soda can recycling programs have resulted in 1 in every 2 soda cans (50.7\%) being recycled (EPA, 2010). However, no national buyback program for agricultural plastic has been introduced. The EPA found that nationwide, only $7.1 \%$ of over 29 million tons of plastic was recycled in 2009 (EPA, 2010). Recycling of horticulture products is further complicated by contamination, such as dirt residue, grease, vegetation, moisture, and pesticide contamination (Garthe and Kowal, 1993). Also, when plants are grown in a nursery or greenhouse setting and exposed to extreme heat and light conditions, this can cause UV light degradation, which can further reduce recyclability.

Since recycling options for containers are limited and reuse is not always feasible, the industry needs to move in a different direction to reduce plastic use and become more sustainable. One possible solution is the use of biodegradable containers, or "biopots."

\section{Biodegradable Containers}

Biopots are containers not produced from petroleum that degrade rapidly (Evans et al., 2010). "Rapidly" could be defined as one plant season, or several years, depending on the type of pots being used. Biopots can be plantable or compostable. Plantable biopots are designed to be left intact on the rootball, and allow the roots to grow through the container walls. Compostable biopots are designed to be removed before planting, broken down, and composted (Evans et al., 2010).

Biopots can be made from a variety of different materials, including but not limited to, peat, paper, coconut fiber, rice hulls, poultry feathers, rice straw, dairy manure, and bio plastics (Evans et al., 2010). Not only do biopots reduce energy consumption, but plantable biopots can also reduce transplant shock and the need for disposal (Evans and Karcher, 2004). Particular 
biopots also have specific added benefits. Coir pots, for example, are made from the fiber of coconut husks and show resistance to bacterial and fungal growth (Tejano, 1985). Another example is the Soilwrap container, marketed by Ball Horticultural company. The Soilwrap is a bottomless wraparound PHA bioplastic "sleeve" consisting of Mirel, a material made from biopolymers produced by microbes that is touted as easy to transport and store (Mohan, 2010). According to Ball Horticulture, 2.5 times more assembled Soilwrap containers can fit on a pallet compared to traditional plastic pots of the same size (Mohan, 2010). Cowpots, made of $100 \%$ renewable cow manure, boast a 12-week bench life before decomposition (Cowpots, 2010). Other pots are made from plant by-products. For example, the Solid Rice Hull and Slotted Rice Hull pots produced by Summit Plastic are made from sustainable rice hull fibers, a renewable resource (Belliveau, 2009). Jiffy and Fertil pots look and feel very similar, but where Jiffy is mostly a peat-based pot, Fertil pots are composed primarily of spruce wood fibers (Fertil, Boulogne Billancourt, France, 2011). Straw pots, produced from natural ingredients including straw, coconut fiber, and a natural latex adhesive, are suggested to biodegrade in three to six months (Van de Wetering, 2008). OP47 pots, or bioplastic wheat pots, are made from biopolymers and look and feel very similar to traditional plastic, but are compostable in appropriate conditions (Belliveau, 2009). Clearly, the biodegradable and plantable pots are publicized as superior to plastic pots for a number of reasons. However, independent verification of claims made by companies producing these pots has been limited to a few studies.

A recent study by Hall et al., (2010) showed that consumers "like" the look of rice hull and straw pots, and "rice hull likers" responded that only $16.5 \%$ of the buying decision was dictated by price. This implies that certain consumers are willing to pay a higher price for an environmentally friendly plant container (Hall et al., 2010). 
If consumers are willing to buy plants in biopots, than why are producers not willing to use them? This could be because the range of concerns with biopots is nearly as long as the list of possible materials used. Concerns range from bench life, to water wicking, to overall aesthetics. This, combined with a lack of research, leaves many large greenhouse and nursery operations leery about trying these relatively new products.

Most biopot research has studied the water use of specific biopots. Evans and Karcher (2004) found that plants in peat and feather fiber biopots required more frequent irrigation and more water overall when compared to plants grown in plastic pots. This is believed to be attributed to a faster rate of evaporation through container walls (Evans and Hensley, 2004). Feather fiber pots were found to wick less water than peat, probably because feathers are hydrophobic, whereas peat is hydrophilic (Evans and Karcher, 2004). Some biopots perform better than others. For instance, a recent study found that rice hull containers performed better than other biopots when it came to frequency of irrigation needed, and bioplastic pots were equal to plastic in regard to water use (Evans et al., 2010).

Another issue that biopots face is their aesthetics once they reach the consumer. Research has shown that certain biopots are more susceptible to algae and fungal growth, which could greatly affect the purchase of these products. Wood fiber and peat pots have the highest probability of algae growth, followed by manures, paper, and rice straw (Evans et al., 2010).

One of the greatest issues facing biopots, undoubtedly fueling the reluctance of growers to switch, is the uncertainty as to whether biopots could endure the production process in the greenhouse and hold up during the marketing to consumer. Research has tested the wet and dry vertical strengths and found that some pots, such as rice hull and manures, have high dry vertical 
strengths, sometimes even higher than plastic. But, the wet strength of biopots was found to be lower than the dry strength (Evans et al., 2010). In fact, wood fiber, peat, and manure pots had such low wet vertical strengths, that manual handling was found to be difficult (Evans et al., 2010). For the most part, it appears that pots that are able to absorb water into the container wall have a significantly lower wet vertical strength (Evans et al., 2010). In addition to concerns about durability there is also apprehension as to how well biopots could be integrated into modern day mechanized operations. Little is known about the compatibility of the products with various machines, and whether the pots can withstand such manipulation. Information currently available is again based on manufacturers' claims with little to no independent research.

\section{Overview and Goal}

In the past several decades, great strides towards increased sustainability in the ornamental horticulture industry have been made. However, significant gaps in the knowledge still remain, including the effects of biopots on plant growth, and their suitability to be used in varying environments.

The goal of this research is to further improve the sustainability of ornamental horticulture by evaluating the performance of various biodegradable pots as a potential alternative for a traditional petroleum-based plastic pot in the greenhouse and landscape settings. 


\section{Objectives}

- Evaluate the effects of biodegradable pots on plant growth in a greenhouse and landscape setting.

- Determine the effects of biodegradable pots on substrate chemistry, such as EC and pH.

- Evaluate the physical characteristics of pots, by evaluating the algal and fungal growth, as well as pot strength at the conclusion of 6-week and 12-week trials.

- Evaluate the percent degradation of pots in a landscape setting.

- Investigate the watering frequency requirements of biodegradable pots 6-week and 12week trials.

- Evaluate the ease of denesting for biodegradable pots. 


\section{Chapter Two: Evaluating the Potential Use of Biopots for Greenhouse Production}

Note: This work is part of a multi-institutional research initiative with additional trials conducted at research facilities associated with the University of Arkansas, University of Kentucky, and University of Illinois. For this thesis chapter, only work conducted at West Virginia University is reported. The final publication to be submitted for peer review will include results from all four locations.

\section{Summary}

As consumers exhibit more and environmental awareness, the horticulture industry is pushed to make their products more environmentally friendly and sustainable. Recent introductions of several new biodegradable containers to the market have led to research investigating biodegradable containers as a potential alternative to petroleum-based plastic containers. This research examines the growth and performance of Impatiens spp. 'Sunpatiens Compact' and Lavendula angustifolia 'Elegans Ice' grown in a greenhouse for six and twelve weeks, respectively, in nine biodegradable containers. Results showed very few significant differences in plant growth and performance between pot types. Subtle and small differences were observed in irrigation frequency. Marked and large differences were recorded in algal growth, punch strength, and tensile strength upon conclusion of the experiments. Factors such as cost, algal growth, pot strength, and perhaps ease of handling will likely play a greater role than plant performance in the industry's future decisions whether or not to embrace these biodegradable pots as alternatives to petroleum-based plastic containers.

\section{Background}

Biodegradable containers, also referred to as biopots, are containers not produced from petroleum derivatives that degrade rapidly in the landscape or in composting facilities (Evans et 
al., 2010). "Rapidly" could be defined as degrading in as little as one season, or multiple years, depending on the type of biopot. Plantable biopots need to degrade within one to two seasons, as they are designed to be left intact on the rootball, and allow the roots to grow through the container walls into the soil after planting. Compostable biopots, on the other hand, are designed to be removed before planting, and may take several years to degrade in a composting facility (Evans et al., 2010).

Biopots can be made from a variety of different organic materials, and in some instances, can not only reduce energy consumption in manufacturing, but can also reduce transplant shock and the need for disposal (Evans and Karcher, 2004). Particular biopots have specific added benefits, such as the resistance to bacterial and fungal growth of coconut fibers used to make coir pots (Tejano, 1985). In addition, some pots have visual appeal and evoke environmental awareness in consumers.

A recent study by Hall (2010) showed that consumers "like" the look of rice hull and straw pots, and "rice hull likers" responded that only $16.5 \%$ of the buying decision was dictated by price. This implies that certain consumers are willing to pay a higher price for an environmentally friendly plant container (Hall, 2010). If consumers are willing to buy plants in biopots, than why has adoption by the horticultural industry been slow? This could be because of the large array of concerns that have been reported, ranging from bench life, to water wicking, to overall aesthetics. In addition, the lack of standardization of new pot introductions to the market has led to problems introducing containers into mechanized operations. This has left many greenhouse operations leery about trying these relatively new products. 
Most biopot research to date has studied the water use, aesthetics, and pot strength of specific biopots. Evans and Karcher (2004) found that plants in peat and feather fiber biopots required more frequent irrigation and more water overall when compared to plants grown in plastic pots. This was thought be attributed to a faster rate of evaporation through container walls (Evans and Hensley, 2004). However, some biopots perform better than others. For instance, a recent study found that rice hull containers performed better than other biopots when it came to frequency of irrigation needed, and pots made from wheat-starch polylactic acid (PLA) bioplastic, were equal to plastic in water use (Evans et al., 2010).

Another issue that biopots face is aesthetics during marketing. Research has shown that certain biopots are more susceptible to algal and fungal growth, which could greatly affect the purchase of these products. In those studies, no algal growth occurred on plastic, PLA bioplastic, coir, or rice hull containers. Wood fiber and peat pots showed the highest probability of algal growth, followed by manure, paper, and rice straw pots (Evans et al., 2010).

One of the greatest issues facing biopots, undoubtedly fueling the reluctance of growers to switch, is the uncertainty as to whether biopots could endure the production process in the greenhouse and hold up during the marketing to consumer. Research has tested the wet and dry vertical strengths and found that some pots, such as rice hull and manure, have high dry vertical strengths, sometimes even higher than plastic. Predictably, the wet strength of biopots was found to be lower than the dry strength (Evans et al., 2010). In fact, wood fiber, peat, and manure pots had such low wet vertical strengths, that manual handling was difficult and damaged the containers (Evans et al., 2010). 
In addition to concerns about durability there is also industry apprehension related to how well biopots could be integrated into modern day mechanized operations (Dr. Sven Verlinden, personal communication). Little is known about the compatibility of the products with various machines, and whether the pots can withstand such manipulation. Information currently available is based on manufacturer's claims with little to no independent research.

In order to provide the greenhouse industry with independent and verifiable information on biopot performance in greenhouse settings, this study evaluated the effect of nine biopots and a plastic control on overall plant growth, plant quality, and pot performance. The work presented here expanded on the research of Evans et al. (2010), by investigating recent market introductions of several new biopots, and two different crop lengths (6-week and 12-week). The objectives of this experiment were to evaluate biodegradable pots and their effects on plant growth parameters, and to investigate container performance in a greenhouse setting, including algal/fungal growth, water usage, and container strength.

\section{Materials and Methods}

\section{$\underline{\text { Location }}$}

The experiments described below were conducted at the West Virginia University greenhouses in Morgantown, WV. Plants were grown under double polyethylene plastic cover in a standard gutter-connected Quonset type structure. Sensors were placed near the plants to measure day and night temperatures (Watchdog Model 125, Spectrum Technologies, Aurora, IL). Container strength and algal growth (see below) were assessed at the University of Arkansas, Fayetteville, AR. 


\section{$\underline{\text { Environment }}$}

The median greenhouse temperature over the course of the 2011 experiment was $22.5^{\circ} \mathrm{C}$, while the 2012 median was $25.6^{\circ} \mathrm{C}$. In the 2011 experiment, a high of $51.2 / 31.1^{\circ} \mathrm{C}(\mathrm{D} / \mathrm{N})$ was recorded on June 9, 2011 and July 12, 2011, respectively. A low of $19.1 / 10.6^{\circ} \mathrm{C}(\mathrm{D} / \mathrm{N})$ was recorded on May 19, 2011 and May 5, 2011, respectively. In the 2012 experiment, a high of 49.6/33.6 ${ }^{\circ} \mathrm{C}(\mathrm{D} / \mathrm{N})$ was recorded on July 7, 2012 and June 29, 2012, respectively. A low of 20.9/13.2 ${ }^{\circ} \mathrm{C}(\mathrm{D} / \mathrm{N})$ was recorded on June 16, 2012 and June 26, 2012, respectively. The 2012 season had numerous days of excessive heat, and the NOAA National Climatic Data Center (NCDC) reports that 2012 was the nationally ranked record warmest summer, and on a statewide basis, temperatures were much above normal for West Virginia (NOAA, NCDC, 2012).

\section{$\underline{\text { Pots }}$}

Nine types of biopots were evaluated for their performance in a greenhouse setting compared to a control plastic pot (Figure 2.1). These pots were either purchased or accepted as donations from their respective manufacturers (Table 2.1). Pot materials included coir (Coir), composted manure fiber (Cowpot), spruce wood fiber (Fertil), peat (Jiffy), rice hulls (Net and Solid Rice Pot), rice straw (Straw), and bioplastic pots made from polylactic acid (PLA) (TerraShell/OP47) and polyhydroxyalkanoate (PHA) bioplastic (Soilwrap). Pots will hereafter be referred to by their material composition.

\section{$\underline{\text { Plant Material }}$}

The plant material used included Impatiens spp. 'Sunpatiens Compact' and Lavendula angustifolia 'Elegans Ice,' purchased in 84-cell plug trays. After greenhouse acclimation (one week), plants were transplanted to 60-cell trays, until ready to be used in the experiment. 
Sunpatiens was selected as a high water requiring, short crop time (6-week) species, and was pinched prior to planting to encourage branching and uniformity. Lavender was selected as a low water requiring, extended crop time (12-week) species. These selections were made to test water use and pot performance under different growing conditions and duration. Performance of pots and plants growth was assessed separately for each species and experiment. Both crops were planted in the respective biopots listed above using approximately 80 grams of Fafard $2^{\circledR}$ (Conrad Fafard Inc., Agawam, MA) media in each pot to ensure uniformity among treatments.

\section{Experimental Design}

Two concurrent experiments, one with the short term crop and one with the long term crop (see above) were performed. In each experiment, six pots of the same biopot type placed in a tray were one replicate. Each biopot was represented by three trays in a completely randomized design, for a total of thirty trays (10 pot types $\mathrm{x}$ three replicates) in each experiment (Figure 2.2). Trays were placed tightly together in three rows of ten trays and each tray was randomly arranged on the bench. Pots in each tray were labeled from left to right, ABCDEF and assigned a number corresponding to its location on the table. For example, 5A would refer to a pot in the lower left corner of a tray positioned in the second column and second row of plants. A oneplant-wide guard row of the same species was placed around the perimeter to reduce border effects in the experiment (Figure 2.2).

These above described experiments were performed twice, once in the spring of 2011 and again in the spring of 2012. The 2011 trial was initiated on May 2, 2011, and concluded for the sunpatiens on June 6 and the lavender on July 4, 2011. The 2012 trial was initiated on May 15, 2012, and concluded on June 26 for the sunpatiens and August 4, 2012 for the lavender. 


\section{$\underline{\text { Irrigation and Fertilization }}$}

A soil moisture probe (SM 100 Waterscout, Spectrum Techonologies, IL.) was used to measure the volumetric water content of the media twice daily at approximately 8-9 AM and again between 2-4 PM. The two visually driest pots in every tray were checked with the probe, and the tray was watered when at least one pot of lavender had a soil moisture at or below $20 \%$ volumetric water content (VWC) and sunpatiens at or below $40 \%$ VWC. These moisture levels were chosen based on species specific needs and visual assessment of plant condition (Dole and Wilkins, 2005; Hanks, 1995). Upon reaching the predetermined VWC, plants were watered in excess of capacity and allowed to drain. Plants were fertilized at every watering with $150 \mathrm{ppm} \mathrm{N}$ for lavender and 250 ppm $\mathrm{N}$ for sunpatiens from a 20-10-20 fertilizer (Scotts, Marysville, $\mathrm{OH}$ ). Watering frequency was recorded for each type of biopot throughout the experiment.

\section{$\underline{\text { Measurements }}$}

Pot performance was analyzed by plant-related measurements such as plant growth (height and width), shoot dry weight, leaf area, and a visual ranking of quality. Additional measurements included biweekly EC/pH measurement, container puncture strength, and container algal/fungal growth at the beginning and end of the experiments.

Height and width growth measurements were taken in each experiment at week 0,3 , and 5 or 6 for sunpatiens, in 2011 and 2012 respectively and week 0, 6, and 10 or 12 for ;avender, in 2011 and 2012, respectively. Height was measured from the media line to the tallest point of the plant, and width measurements were taken in East-West and North-South directions and then averaged. 
At the end of the experiment (week 5 or 6 for sunpatiens and week 10 or 12 for lavender), plants were severed at the base and immediately weighed to collect fresh weight data. Next, the leaves were stripped from the plant and used to measure leaf area with a leaf area meter (LI-3100 Area Meter, Li-cor, Lincoln, NE). After the leaf area measurements, all plant parts were collected and placed into paper bags, labeled, and dried in a drying room at $46^{\circ} \mathrm{C}$. After two weeks, the samples were removed from the drying rooms and immediately weighed for dry weight determination.

At the conclusion of each experiment, plants were photographed and assigned a numerical value indicating overall quality. Quality scores ranged from 1-5. A score of "1" represented a plant that was completely dead, with no green growth apparent, while "2" represented plants that still had some green growth but were of very poor quality. Scores of "3" were given to plants of fair quality, such as plants stunted in growth, or with noticeable insect damage. Good quality marketable plants with open flowers and limited insect damage and blemishes were scored a "4", and plants that were considered excellent quality, with little to no insect damage, and adequate size with several open flowers, were scored a "5" (Figure 2.3).

Biweekly EC/pH measurements were taken using the pour thru method (Cavins et al., 2005). Plants were watered to saturation one hour in advance of $\mathrm{EC} / \mathrm{pH}$ measurements and allowed to drain. Containers to catch leachate were placed in groups of six and each tray was placed on the containers so that each pot corresponded to a container. Eighty $\mathrm{ml}$ of additional water was added and allowed to drain for 5 minutes. Leachate was collected and measured using an EC/pH meter (Ultrameter 6P, Myron L Company, Lincoln, NE). 
After harvesting the plants for fresh and dry weight determination, the pots were dried for one week at room temperature, and the media was carefully removed. The pots were then placed in individually labeled plastic bags and tied off so that air was left in the bag to cushion and protect the pots during shipping. Pots were shipped to the University of Arkansas (Dr. Mike Evans' laboratory) where they were tested for container strength and algal/fungal growth. Specifically, the pots were analyzed for wet and dry strengths using a TAXT 21 Texture Analyzer (Texture Technologies, Scarsdale, NY). The pressure required to crush each pot vertically and laterally was recorded, as was the pressure required to punch through the container wall (Evans et al., 2010). Algal/fungal growth was quantified by cutting sections of discoloration using a box cutter, and running the samples through a leaf area meter to get an overall area of algal coverage.

\section{$\underline{\text { Statistical Analysis }}$}

Data were analyzed separately by species and year (2011 and 2012) due to differences in experimental protocol, such as duration of the experiments between species, and also environmental differences between years. Meaningful and direct comparisons between 2011 and 2012 can only be made on a limited basis, as experiments were ended early in 2011 due to the flowering of plants (sunpatiens) and excessive heat in July (lavender).

Prior to analysis using Sigma Plot (Systat Software, Inc, San Jose, CA), pseudoreplication resulting from data obtained from individual pots was averaged to produce three measurements (one per tray) for each experiment. The data were tested for homogeneity of variances using Bartlett's Test, and for normality using the Shapiro-Wilk test. 
Plant growth measurements, such as fresh weight, dry weight, leaf area, ranking, and final width and final height were analyzed by year and species using a series of One Way Analysis of Variances (ANOVAs). If pot type effects (treatment) were found, pairwise multiple comparisons were made using the Holm-Sidak method.

Pot measurements, such as punch strength, tensile strength, algal growth, and watering frequency were analyzed by year and species using ANOVA, and pairwise multiple comparisons were made when indicated using the Holm-Sidak method.

EC and $\mathrm{pH}$ were assessed per year and species using a One-Way ANOVA with repeated measures to show difference between weeks, and by a Two-Way ANOVA to show interactions between pot type and week. Pairwise multiple comparisons of weeks were made using the Holm-Sidak method. Pairwise multiple comparisons of the interaction of pot type by week were made using the Tukey's Standardized Range Test.

\section{Results and Discussion}

\section{Plant Growth}

When we compared plant growth among the nine biopots studied, no significant differences were observed in any of the plant growth measurements we employed (fresh weight, dry weight, final width, final height, or final leaf area) in 2011 for sunpatiens or lavender (Table 2.2 and 2.3). The ANOVA on visual ranking measurements of lavender did show significant differences among treatments in 2011. However, those differences could not be resolved with a separation of means test (Tukey's or Holms-Sidak). 
Significant differences in plant growth parameters were observed in the 2012 growing season (Tables 2.4 and 2.5). For the short term sunpatiens trial, these differences were in fresh weight $(P<0.001)$ and dry weight $(P<0.001)$ of plants, as well as the final height $(P=0.015)$. PHA bioplastic pots produced plants with fresh weights that were significantly higher than coir, wood pulp, peat, slotted and solid rice hull, and straw. However, dry weights of PHA bioplastic pots was greater than that of coir, straw and slotted rice hull. For final heights, differences occurred only between the plant heights of the manure and coir pots. On average, manure pot plants measured $18.5 \mathrm{~cm}$, whereas plants in coir pots averaged $14.9 \mathrm{~cm}$ at the end of the experiment. Despite these differences in fresh weight, dry weight, and final height, in most instances no significant differences were observed between control plastic pots and biodegradable pots. The only exception here is the underperformance of straw and slotted rice hull pots compared to control plastic pots in dry weight in 2012.

Lavender in 2012 showed significant differences in final width $(P=0.021)$. Differences were observed between the solid rice hull plants, averaging $16.5 \mathrm{~cm}$ wide, and the plants in coir and peat pots, with widths averaging $13 \mathrm{~cm}$ and $12.9 \mathrm{~cm}$, respectively. In 2012, the final height of lavender and the final leaf area of sunpatiens showed significant treatment effects in the Analysis of Variance ( $P=0.039$ and 0.040 , respectively), but these differences again could not be resolved by a separation of means test.

Overall, few differences were observed in measurements relating to plant growth in sunpatiens and lavender. The observation that there were no significant differences in plant growth and development measurements, for either species in 2011, yet slight differences in 2012, could be attributed to somewhat different durations of the experiments and environmental factors. Additionally, some of the differences in plant measurements between pot types in the 
2012 short term experiment are not observed in the 2012 long term experiment. This suggests that the differences observed in the 2012 sunpatiens plant growth could be plant specific, or that given a longer production time, differences in plant growth among the pot types eventually disappear.

These results are similar to those reported by several other studies. In an experiment by Evans and Hensley (2004), all plants were watered as needed, and no significant differences were found in dry shoot weights of Vinca or Impatiens grown in plastic or peat pots. Significantly higher shoot weights were observed in plants grown in feather fiber pots, but the author attributed this increased growth to additional nitrogen availability from the container walls (Evans and Hensley, 2004).

A more recent study expanded on the work of Evans and Hensley, and evaluated the plant growth of seven biopots, using three different irrigation methods. Their results also indicated that plants grown in biopots were of equal size and quality as those grown in conventional plastic containers within each of the irrigation types tested (Koeser et al., 2013b). In short, very few differences have been observed in previous studies and our work corroborates these observations.

In light of this, it is important to note that visual ranking was conducted for both seasons of lavender crops, and no differences were apparent among pot types. Despite the fact that some differences did occur between the four experiments, the data suggests that most biodegradable pots are capable of producing marketable crops that are comparable in size and appearance to the same species of crop grown in a traditional plastic pot. 


\section{Substrate Chemistry}

The analysis of substrate $\mathrm{pH}$ for sunpatiens and lavender in 2011 showed significant differences between pot type $(P<0.001)$, week $(P<0.001)$, and a pot by week interaction $(P<0.001)$. The general trend that was observed, for both species, was a decrease in average $\mathrm{pH}$ over the trial. Specifically, the last week of each experiment had significantly lower $\mathrm{pH}$ values than all other weeks (Table 2.6 and 2.7, Figure 2.4 and 2.5). In comparison to other pots at the end of the sunpatiens trial, manure and straw pots had the highest leachate $\mathrm{pH}$, with 6.4 and 6.3 respectively. The lowest leachate $\mathrm{pH}$ was observed in the peat (5.2), solid rice hull (5.4), and the PLA bioplastic (5.4). At the ten-week conclusion of the lavender trial, manure, straw, and slotted rice hull showed an elevated leachate $\mathrm{pH}$ compared to all other pots, with a $\mathrm{pH}$ of $6.5,6.3$, and 6.3 respectively, similar to the observations made in the sunpatiens trial. Peat, plastic, and solid rice hull showed the lowest $\mathrm{pH}$, with a $\mathrm{pH}$ of 5.7, 5.7, and 5.7, respectively, again similar to the sunpatiens trial observations.

The analysis of $\mathrm{pH}$ for the sunpatiens and lavender trials in 2012 also showed significant differences between pot type $(P<0.001)$, week $(P<0.001)$, and a pot by week interaction $(P<0.001)$. However, no clear trend, as observed in 2011 , was discernible in 2012 . The only conclusion that can be drawn is that $\mathrm{pH}$ fluctuated significantly over time, and pot type had some influence over $\mathrm{pH}$ (Table 2.8 and 2.9 and Figure 2.6 and 2.7). Similar to the 2011 end results, manure and straw pots again had the highest $\mathrm{pH}$, while peat, solid rice hull, and plastic had the lowest $\mathrm{pH}$ values in the 2012 trial, but those differences were less profound. During the final week of the experiment, manure, slotted rice hull, and straw pots again showed the highest $\mathrm{pH}$, but were only different from that of the peat pots, with the lowest $\mathrm{pH}$. 
In all four experiments, leachate $\mathrm{pH}$ of the manure, straw, and slotted rice hull treatments was elevated, especially early on in the experiments. Leaching of pot material from the composted cow manure pots (a neutral $\mathrm{pH}$ material) could have led to an elevated $\mathrm{pH}$ during the initial stages of the experiment. However, it is unclear why the straw and slotted rice hull pots showed elevated $\mathrm{pH}$ readings in our study, but one could speculate that pot composting due to the addition of fertilizer could lead to higher leachate $\mathrm{pH}$ readings. Again, when $\mathrm{pH}$ readings are compared to the 2012 plant growth results, no pattern is discernible between $\mathrm{pH}$ and plant growth.

The $\mathrm{pH}$ range recommendation for sunpatiens is between 5.8 to 6.3 , while lavender prefers a slightly more alkaline range of 6.0 to 8.0 (Ball, 1998). In the 2011 sunpatiens trial, all pots had leachate $\mathrm{pH}$ above the recommended range during Week 0 or Week 2, and by the final week of the experiment, wood fiber, peat, PLA bioplastic, plastic, and solid rice hull had fallen below the recommended range. A similar drop below the recommended range was also observed during the final week of the 2011 lavender trial. However, these changes in $\mathrm{pH}$ likely did not affect plant growth, as no significant differences were apparent in the 2011 plant growth data, and no pattern was discernible when plant growth differences in 2012 were compared to $\mathrm{pH}$ measurements.

In conclusion, some differences were observed in $\mathrm{pH}$ between pot types over the course of the experiments. Leachate $\mathrm{pH}$ did fluctuate outside of the recommended range, however these $\mathrm{pH}$ readings did not significantly impact plant growth and development. The use of some pots, such as composted manure, straw, and slotted rice hull, should be accompanied with a cautionary note that the use of these pots may contribute to higher media PH than plastic pots, while the use of peat pots can lead to a slightly lower media $\mathrm{pH}$. 
In the sunpatiens trials in 2011 and 2012, significant differences among least square means of Electrical Conductivity (EC) were observed in both pot $(P<0.001)$ and week $(P<0.001)$ effects (Tables 2.10 and 2.12 and Figure 2.8 and 2.10). A significant pot vs. week interaction was observed in $2011(P=0.001)$, but not in the 2012 sunpatiens data $(P=0.085)$. Slotted rice hull and coir pots had a significantly higher EC than that of the peat pot in week 0 of the 2011 trial. In week 5, manure, wood fiber, and peat pots had a significantly higher EC than that of the plastic pot. Overall, the EC during the 2011 trial dipped in week 2, and steadily rose during week 4 and 5 (Table 2.10 and Figure 2.8). In the 2012 sunpatiens trial, a pattern emerged with EC steadily increasing over the duration of the trial (Table 2.12 and Figure 2.10). Although no differences were apparent in the pot vs. week interaction, differences were observed in pot types. Specifically, coir and slotted rice hull had significantly higher EC levels than the PHA bioplastic pot throughout the trial.

In the 2011 lavender trial, differences in EC were observed among pots $(P<0.001)$, weeks $(P<0.001)$, and pot vs. week $(P=0.018)$ effects. Overall, EC showed a gradual increase and the highest readings were recorded during the final week of the experiment (Table 2.11 and Figure 2.9). Pots vs. week interactions were observed in nearly every biweekly measurement. In week 0 , differences were apparent between coir and peat, and in Week 2, coir differed from wood fiber and peat. In week 6 , coir and solid rice hull differed from manure. In week 8 , coir differed from PHA bioplastic while in week 10, only solid rice hull differed from PHA bioplastic (Table 2.11 and Figure 2.9).

In 2012, differences were again observed between pots $(P=0.002)$, weeks $(P<0.001)$, and pot vs. week $(P=0.001)$. However, no clear patterns in $\mathrm{EC}$ over time or between weeks were apparent during the lavender 2012 trial. Initially, coir and slotted rice hull pots differed from 
wood fiber and peat, but by Week 2, only plastic differed from peat and manure. Between weeks 4 and 8, the overall EC measurements fluctuated dramatically. However, all pot types maintained statistically similar EC levels during Weeks 4, 6, 8, and 12. During Week 10, only manure differed from PLA bioplastic (Table 2.13 and Figure 2.11).

Overall, coir showed an elevated average EC during all four experiments, but was only significantly different from that of the plastic control pot in Week 0 for the lavender experiment in 2011. It is recommended that EC levels be below 4.5 to $5.0 \mathrm{dS} / \mathrm{m}(4500-5000 \mathrm{mS} / \mathrm{cm})$ for the pour through method (Nelson, 2002). New Guinea Impatiens are especially sensitive to salt accumulation (Dole and Wilkins, 2005). Throughout the duration of all four trials, recorded EC levels never exceed this critical point. In conclusion, despite EC fluctuations and differences among pot types, it is unlikely that EC significantly affected plant growth, as significantly high or low EC measurements did not seem to match any patterns observed in plant growth.

\section{Watering Frequency}

Both species required more frequent watering during the 2012 season compared to the 2011 season. For example, peat pots in the 2011 lavender trial were watered 25 times during the season, in comparison to 36 times in the 2012 lavender trial. This was likely due to the shorter duration of the experiment, but also environmental factors, such as a higher median temperature in the 2012 season.

In the short term sunpatiens crop, no significant differences $(P=0.258)$ were seen in watering frequency for the 2011 season (Table 2.14). However, there was a significant difference in watering frequency among pots for the 2012 season $(P<0.001)$. Wood fiber, peat, and manure pots were among the top tier of pots in watering frequency, and slotted rice hull, straw, and PHA 
bioplastic were among the lowest tier of water requirements. In comparison to the plastic control pot, which required a watering frequency of 21.3, only the PHA bioplastic differed with an average frequency of 16.3 (Table 2.16).

Although differences were not seen in 2011 for the short term sunpatiens, differences in watering frequency were significant for the long term lavender 2011 trial $(P=0.006)$. In the lavender 2011 trial, the peat pot, with a watering frequency of 25.0, differed from the PLA bioplastic and PHA bioplastic pots, with an average number of watering of 13.6 and 14.0, respectively. However, no pots were significantly different from that of the plastic control pot in watering frequency (Table 2.15). In the lavender 2012 trial, significant differences $(P=0.002)$ were observed between coir and peat pots, both requiring an average watering frequency of 36.3 , and the PHA bioplastic and straw pots, with 27.3 and 27.0, respectively. Again, no pot types were significantly different from that of the plastic control pot in the number of watering events (Table 2.17)

Over all four trials, the peat pot maintained the highest average watering frequency compared to all other pots, while PHA bioplastic and straw pots were among the lowest water requiring treatments. Although peat did consistently have the highest average watering frequency, the peat pot was not statistically different from the plastic control pot in any of the four trials. Furthermore, with the exception of the PHA bioplastic during the sunpatiens 2012 trial, all pots tested had watering frequencies that were not significantly different from that of the plastic control pot.

A similar study conducted at the University of Illinois measured the water use of biocontainers in a greenhouse setting. Plants were watered by hand using a beaker when the soil 
moisture levels were at or below $40 \%$ VWC. Water use was calculated as the difference between the volume of water applied and the volume of water lost through drainage. The results showed that containers made of porous material used greater volumes of water, and that the wood fiber pot required the highest amount of water overall. However, the author notes that the use of shuttle trays and potting mix optimization may negate some of the differences observed (Koeser et al., 2013a).

These results suggest that most biodegradable pots have similar watering requirements to traditional plastic pots, but growers should be alerted to possible higher watering frequencies of biopots made of porous materials, such as the peat, coir, wood fiber, and manure pots.

\section{$\underline{\text { Algal Growth }}$}

Percent algal growth differed significantly by pot type in both species during both seasons (Table 2.14, 2.15, 2.16 and 2.17). Most containers, however, showed no algal growth. Only peat, wood fiber, and to a lesser degree, manure containers showed algal growth at the end of the experiment. In the 2011 and 2012 sunpatiens trials, peat pots had mean algal coverage areas of $34.0 \mathrm{~cm}^{2}$ and $37.6 \mathrm{~cm}^{2}$, respectively. During the lavender 2011 and 2012 trials, peat showed areas of $142.2 \mathrm{~cm}^{2}$ and $68.9 \mathrm{~cm}^{2}$ covered with algae, respectively. Similar results were shown with the wood fiber pots, with $38.4 \mathrm{~cm}^{2}$ and $40.2 \mathrm{~cm}^{2}$ of coverage during the 2011 and 2012 sunpatiens trial, and an average pot area of $97.2 \mathrm{~cm}^{2}$ and $89.9 \mathrm{~cm}^{2}$ covered with algae during the 2011 and 2012 lavender trials. Algal coverage of manure pots for lavender 2012 was not available due to the degradation of the pots at the end of the experiment, and no algal growth was reported on manure pots in the sunpatiens 2011 trial. However, manure pots did have algal growth of $24.1 \mathrm{~cm}^{2}$ in the 2012 sunpatiens trial, and $1.9 \mathrm{~cm}^{2}$ in the 2011 lavender trial. Higher 
levels of algal growth were observed on peat and wood fiber pots as the time of production in the greenhouse increased. At the conclusion of the long term experiments, every peat and wood fiber pot had measureable algae growth. These results are similar to those observed at the University of Illinois, in which wood fiber and peat pots also showed algal growth during a six-week trial, and algal growth became more widespread as the study time increased. After the 12-week trial, algal growth was reported on wood fiber, peat, and manure pots (Koeser, 2013). Algal growth could weaken the overall appearance of a marketable product, and may have a negative impact on a consumer's willingness to purchase plants.

\section{Container Strength}

The punch strength of the biopots differed significantly by container type for sunpatiens in 2011 and $2012(P<0.001)$, and also for lavender in 2011 and $2012(P<0.001)$. Plastic containers offered high punch strengths with means ranging from $14.4 \mathrm{~kg}$ to $20.0 \mathrm{~kg}$. Only the coir containers in the short term sunpatiens trials provided punch strengths similar to plastic (Table 2.14, 2.15, 2.16, and 2.17). In all other trials, all nine biopots had significantly lower punch strengths than that of the plastic control pot. Specifically, manure, peat, and wood fiber pots consistently showed the lowest punch strengths, ranging from $0.1 \mathrm{~kg}$ to $0.6 \mathrm{~kg}$.

Tensile strength varied significantly by container type. Five containers had tensile strengths consistently above $10 \mathrm{~kg}$ : coir, slotted rice hull, PLA bioplastic, plastic, and solid rice hull (Table 2.14, 2.15, 2.16 and 2.17). Manure and wood fiber containers consistently had tensile strengths at $0 \mathrm{~kg}$ for all trials. The peat pot showed a tensile strength of $1.9 \mathrm{~kg}$ in the sunpatiens 2012 trial, but 0 in all other trials, while the straw pot had average tensile strengths between 2.2 and 5.7. Similar research conducted by Evans et al., (2010), found that containers "required a 
minimum of $2 \mathrm{~kg}$ wet vertical and punch strength... (at) less than $2 \mathrm{~kg}$, the containers tended to tear or break, and handling became problematic." In the short term six-week trial, manure, wood fiber, and peat pots had tensile and/or punch strengths below Evans' recommended critical point of $2 \mathrm{~kg}$. After twelve weeks in greenhouse production, this list grew to include slotted rice hull, straw, PLA bioplastic, and PHA bioplastic pots.

\section{Conclusion}

In terms of measurements related to plant growth, few differences were seen between pot types. In those cases where there were significantly different results in plant growth parameters between pot types, it should be noted that all plants were still of good to excellent marketable value.

These results suggest that when choosing a pot type, other factors will likely play a bigger role than that of plant growth. One such factor could be that of algal growth. Significant algal growth occurred on peat and wood fiber pots in particular, and this may have a negative effect on consumer appeal at the time of marketing. Container strength is another factor that will also play an important role in pot selection. Four pots in particular had low punch and tensile strengths: manure, wood fiber, peat, and straw. For a producer, these pots could cause significant problems in terms of handling, especially in mechanized settings.

Coir, slotted rice hull, solid rice hull, PLA bioplastic, and PHA bioplastic pots had adequate punch and tensile strengths, showed no algal growth, and showed similar watering frequencies to that of a traditional plastic pot. However, slotted rice hull pots showed elevated $\mathrm{pH}$ readings throughout, and should come with a cautionary note to growers. Until more research 
is conducted, coir, solid rice hull, PLA bioplastic, and PHA bioplastic pots could be considered superior based on our results.

The most likely contributing factor to that of pot selection will be cost. Consumer willingness to pay a higher price for biodegradable pots has been studied. Yue et al., (2010) found that survey participants were willing to pay approximately a $\$ 0.58$ premium per rice hull pot, $\$ 0.37$ premium per straw pot, and $\$ 0.23$ premium for each PLA bioplastic pot, compared with traditional plastic containers. But, additional costs other than the initial pot price must also be considered. Many of the biodegradable pots are hard to separate, and could cause a costly increase in labor required at planting time (see addendum, page 81). Factors such as this need to be further researched before biodegradable plant pots can be unequivocally recommended as alternatives to plastic pots in floriculture production. 
Figure 2.1. Containers used for the study. Top row, left to right: Peat, straw, coir, manure. Bottom row: Slotted rice hull, solid rice hull, plastic pot, PHA bioplastic sleeve. Not pictured: Wood fiber, PLA bioplastic pot.

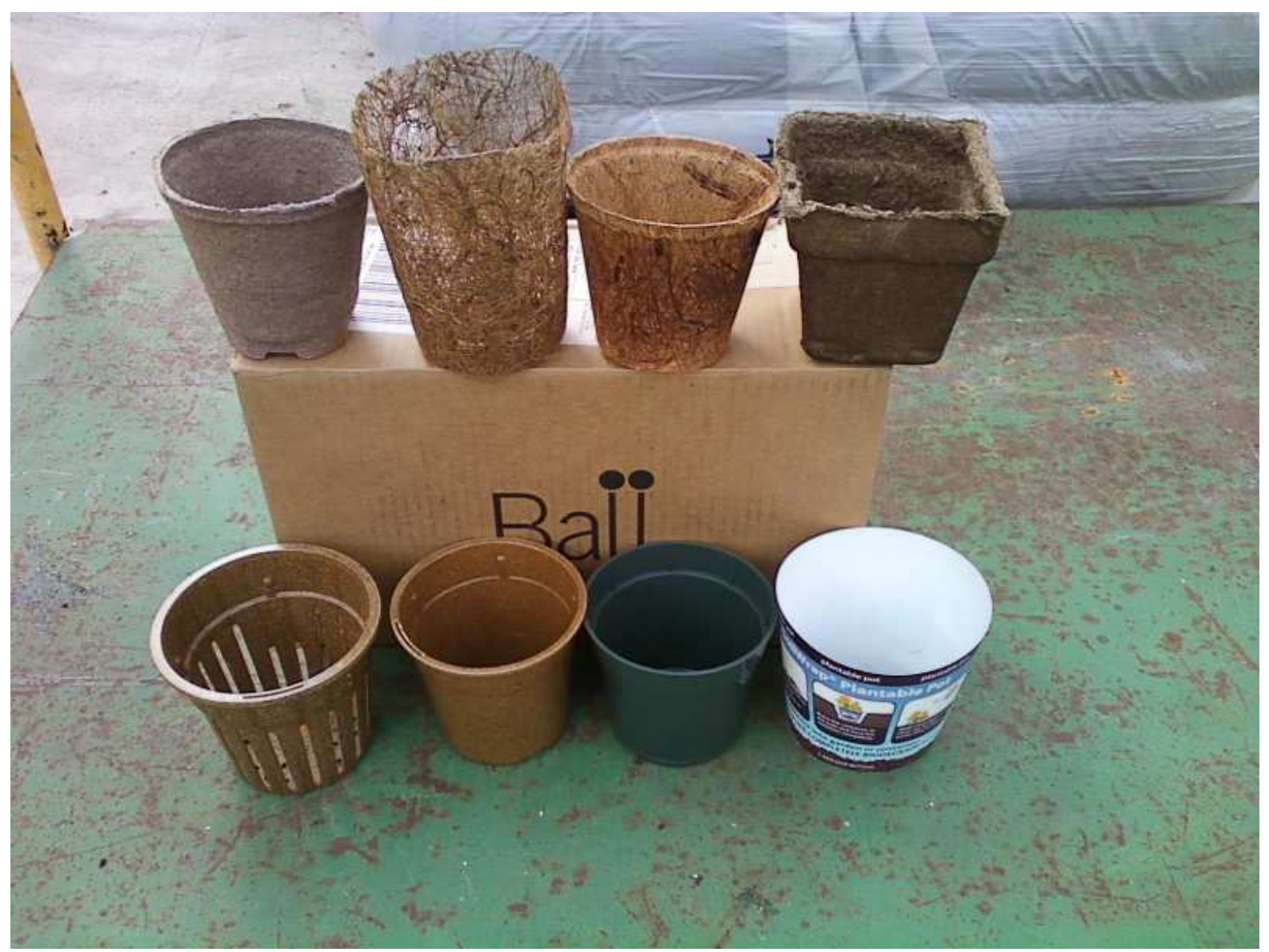


Table 2.1 Container types and manufacturers of pots used in this experiment.

\begin{tabular}{|c|c|c|}
\hline Product Name & Container Component & Manufacturer \\
\hline $\begin{array}{l}\text { Dillen 04.00 Standard } \\
\text { Thinwall Green }\end{array}$ & $\begin{array}{l}\text { Injection molded plastic } \\
\text { (Plastic) }\end{array}$ & $\begin{array}{l}\text { Myers Industries Lawn \& } \\
\text { Garden Group, Middlefield, } \\
\text { OH }\end{array}$ \\
\hline Coir 4.0" Std Fiber Gro Pot & Pressed coconut fiber (Coir) & $\begin{array}{l}\text { Dillen Products, Middlefield, } \\
\text { OH }\end{array}$ \\
\hline \#4 Square Manure & $\begin{array}{l}\text { Composted Manure Fiber } \\
\text { (Manure) }\end{array}$ & $\begin{array}{l}\text { Manures Manufacturing and } \\
\text { Sales, East Canaan, CT }\end{array}$ \\
\hline $\begin{array}{l}10 \times 10 \mathrm{~cm} \text { Round Individual } \\
\text { Wood fiberpot }\end{array}$ & $\begin{array}{l}\text { Steam-Pressed Spruce Wood } \\
\text { Fiber (Wood Fiber) }\end{array}$ & $\begin{array}{l}\text { Wood fiberSAS, Boulogne } \\
\text { Billancourt, France }\end{array}$ \\
\hline 4" Peat Pot & $\begin{array}{l}\text { Peat and Recycled Paper } \\
\text { (Peat) }\end{array}$ & $\begin{array}{l}\text { Peat Products of America Inc., } \\
\text { Lorain, OH }\end{array}$ \\
\hline 4.5" Net rice hull & Rice Hulls (Slotted Rice Hull) & $\begin{array}{l}\text { Summit Plastic Company, } \\
\text { Akron, OH }\end{array}$ \\
\hline $\begin{array}{l}\text { 4.5" Standard Assembled } \\
\text { Soilwrap Sleeve }{ }^{\circledR}\end{array}$ & $\begin{array}{l}\text { Polyhydroxyalkanoate } \\
\text { Bioplastic Sleeve (PHA } \\
\text { bioplastic) }\end{array}$ & $\begin{array}{l}\text { Ball Horticultural Company, } \\
\text { West Chicago, IL }\end{array}$ \\
\hline Rice Pot 4" & Rice Hulls (Solid Rice Hull) & $\begin{array}{l}\text { Summit Plastic Company, } \\
\text { Akron, OH }\end{array}$ \\
\hline $\mathrm{n} / \mathrm{a}$ & $\begin{array}{l}\text { 80:20 Rice Straw:Coconut } \\
\text { Fiber with Latex Binder } \\
\text { (Straw) }\end{array}$ & $\begin{array}{l}\text { Ivy Acres, Baiting Hollow, } \\
\text { NY }\end{array}$ \\
\hline TerraShell ${ }^{\mathrm{TM}} 10 \mathrm{~cm} \mathrm{H}$ Wheat & $\begin{array}{l}\text { Wheat-Starch polylactic acid } \\
\text { bioplastic (PLA Bioplastic) }\end{array}$ & $\begin{array}{l}\text { Summit Plastic Company, } \\
\text { Akron, OH }\end{array}$ \\
\hline
\end{tabular}


Figure 2.2. Experimental design of the greenhouse experiment.
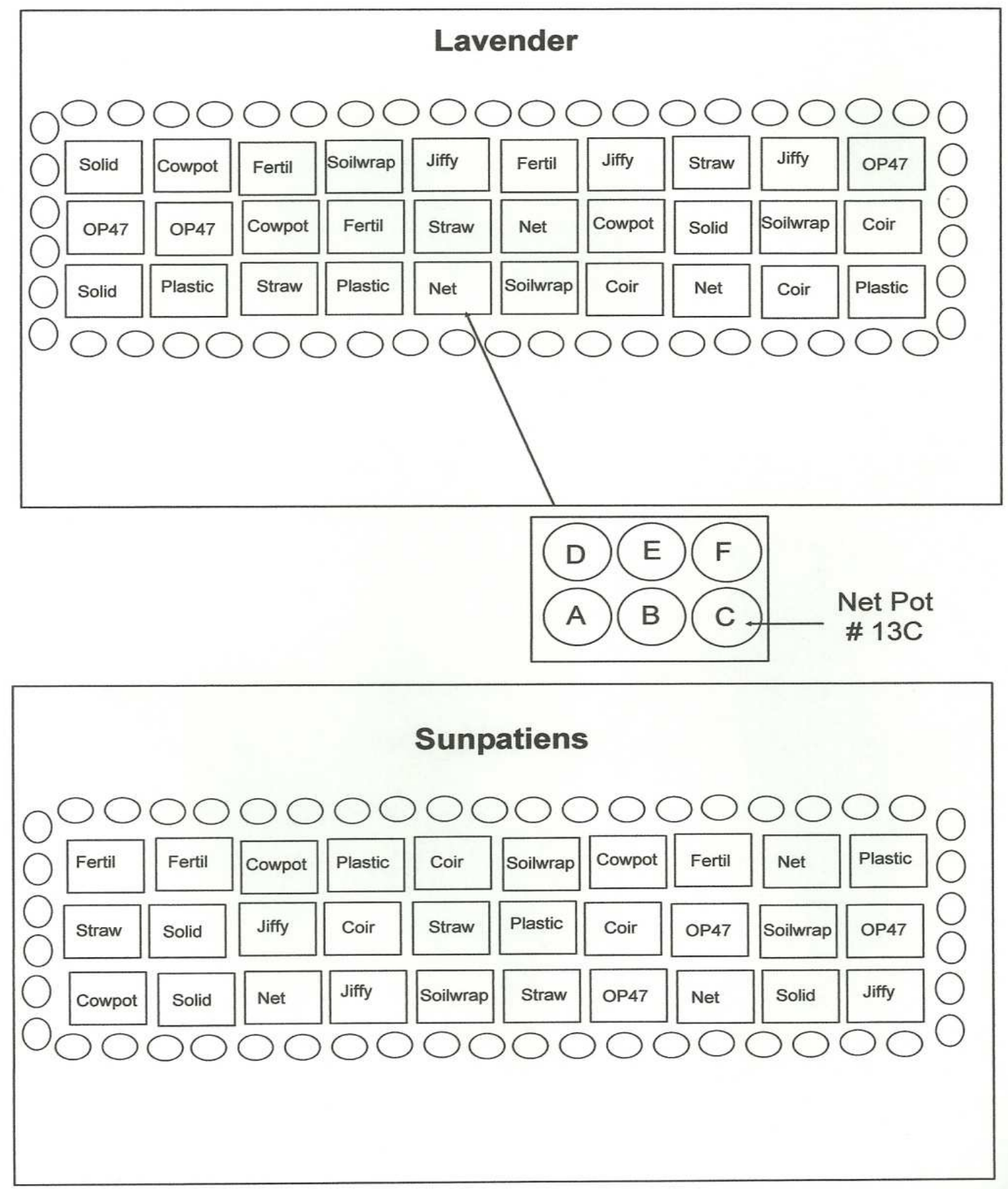
Figure 2.3. Photographs depicting visual ratings of Lavendula angustifolia 'Elegans Ice' in 2011. From left to right, "1", "3", and "5".

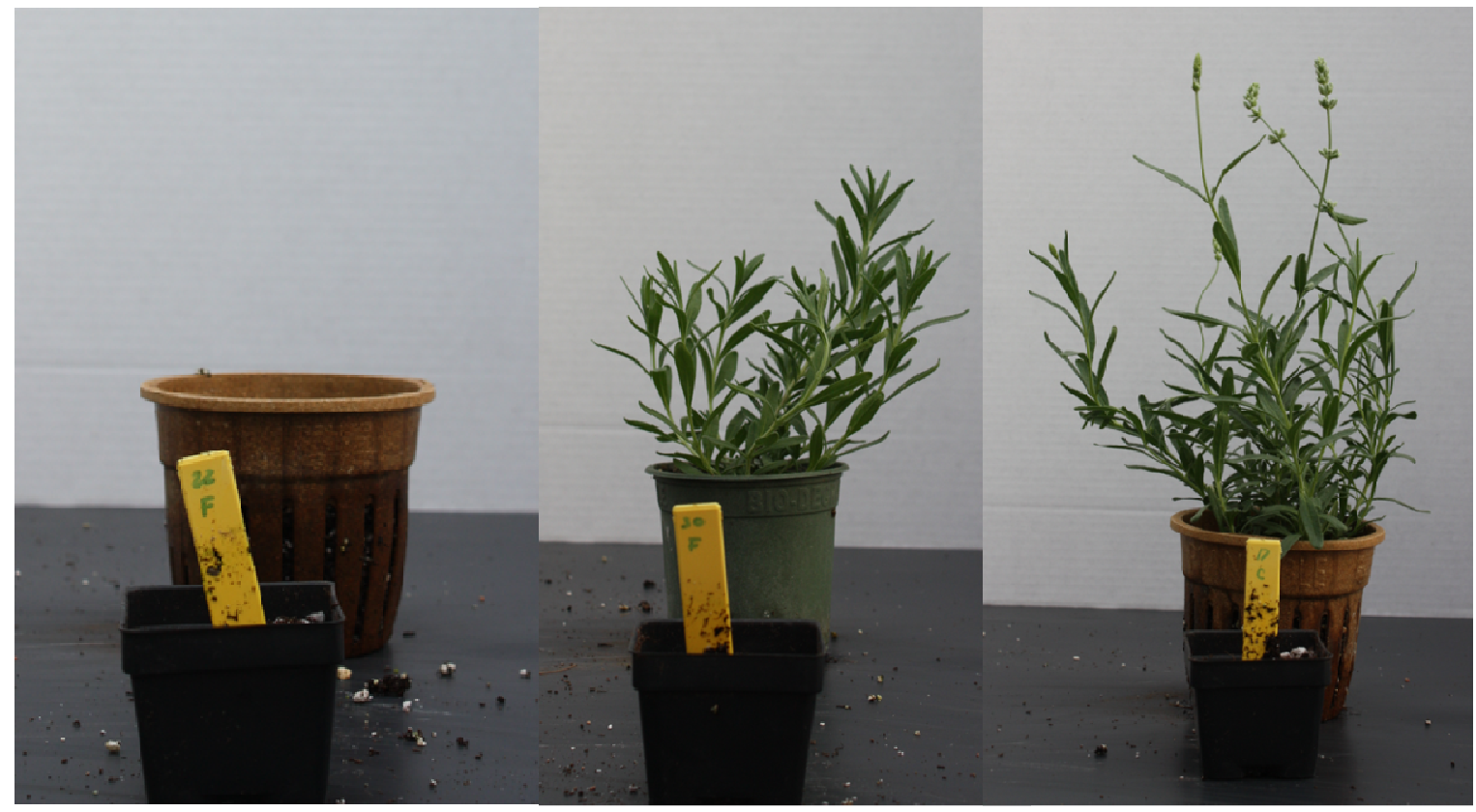


Table 2.2. Final plant growth of Impatiens spp. 'Sunpatiens Compact' grown in a greenhouse for five weeks in 2011 using biodegradable plant pots.

\begin{tabular}{|c|c|c|c|c|c|}
\hline Container Type & Fresh Wt $(\mathrm{g})^{\mathrm{yz}}$ & Dry Wt. $(g)^{\mathrm{yz}}$ & $\begin{array}{l}\text { Final Width } \\
(\mathrm{cm})^{\mathrm{xz}}\end{array}$ & $\begin{array}{c}\text { Final Height } \\
(\mathrm{cm})^{\mathrm{yz}} \\
\end{array}$ & $\begin{array}{l}\text { Final Area } \\
\left(\mathrm{cm}^{2}\right)^{\mathrm{yz}}\end{array}$ \\
\hline Coir & $59.7 \mathrm{a}$ & $3.7 \mathrm{a}$ & $23.3 \mathrm{a}$ & $13.7 \mathrm{a}$ & $681.8 \mathrm{a}$ \\
\hline Manure & $68.3 \mathrm{a}$ & $4.1 \mathrm{a}$ & $23.7 \mathrm{a}$ & $15.6 \mathrm{a}$ & $754.2 \mathrm{a}$ \\
\hline Wood Fiber & $66.0 \mathrm{a}$ & $4.1 \mathrm{a}$ & $22.8 \mathrm{a}$ & $14.1 \mathrm{a}$ & 779.6 a \\
\hline Peat & $66.1 \mathrm{a}$ & $3.9 \mathrm{a}$ & $24.2 \mathrm{a}$ & $14.8 \mathrm{a}$ & 780.1 a \\
\hline Slot. Rice Hull & $68.7 \mathrm{a}$ & $4.4 \mathrm{a}$ & $24.4 \mathrm{a}$ & $13.5 \mathrm{a}$ & $767.3 \mathrm{a}$ \\
\hline PLA Bioplastic & $58.3 \mathrm{a}$ & $3.6 \mathrm{a}$ & $22.8 \mathrm{a}$ & $13.2 \mathrm{a}$ & $696.2 \mathrm{a}$ \\
\hline PHA Bioplastic & $73.0 \mathrm{a}$ & $4.6 \mathrm{a}$ & $24.2 \mathrm{a}$ & $14.6 \mathrm{a}$ & $829.7 \mathrm{a}$ \\
\hline Solid Rice Hull & $62.6 \mathrm{a}$ & $3.8 \mathrm{a}$ & $23.6 \mathrm{a}$ & $14.3 \mathrm{a}$ & 715.7 a \\
\hline Straw & $60.4 \mathrm{a}$ & $3.8 \mathrm{a}$ & $23.1 \mathrm{a}$ & $14.2 \mathrm{a}$ & $698.0 \mathrm{a}$ \\
\hline Plastic & $65.8 \mathrm{a}$ & $4.4 \mathrm{a}$ & $23.7 \mathrm{a}$ & $14.6 \mathrm{a}$ & $742.3 \mathrm{a}$ \\
\hline $\mathrm{P}$ value & 0.278 & 0.269 & 0.710 & 0.823 & 0.548 \\
\hline
\end{tabular}

Experimental units were replicated three times. Statistical analysis using ANOVA with Holm-Sidak method was used to indicate if treatments were different from other treatments (as indicated by lower case letters). All measurements were taken at the end of the five week experiment.

${ }^{\mathrm{z}}$ Means in a column followed by different letters are significantly different at the $P \leq 0.05$ level, Holm-Sidak method.

${ }^{\mathrm{y}}$ Data passed Normality Test (Shapiro Wilk) and Equal Variance Test.

${ }^{\mathrm{x}}$ Data passed Equal Variance Test, but failed Normality Test (Shapiro Wilk). 
Table 2.3. Final plant growth of Lavendula angustifolia 'Elegans Ice' grown in a greenhouse for ten weeks in 2011 using biodegradable plant pots.

\begin{tabular}{|c|c|c|c|c|c|c|}
\hline Container Type & Fresh Wt $(\mathrm{g})^{\mathrm{yz}}$ & Dry Wt. $(g)^{\mathrm{yz}}$ & $\begin{array}{c}\text { Final Width } \\
(\mathrm{cm})^{\mathrm{yz}}\end{array}$ & $\begin{array}{c}\text { Final Height } \\
(\mathrm{cm})^{\mathrm{yz}}\end{array}$ & $\begin{array}{c}\text { Final Area } \\
\left(\mathrm{cm}^{2}\right)^{\mathrm{wz}}\end{array}$ & Ranking $^{\mathrm{xz}}$ \\
\hline Coir & $19.1 \mathrm{a}$ & $3.5 \mathrm{a}$ & $11.5 \mathrm{a}$ & $26.4 \mathrm{a}$ & $381.4 \mathrm{a}$ & $4.5 \mathrm{a}$ \\
\hline Manure & $21.3 \mathrm{a}$ & $3.7 \mathrm{a}$ & $12.9 \mathrm{a}$ & $34.6 \mathrm{a}$ & $439.4 \mathrm{a}$ & $4.7 \mathrm{a}$ \\
\hline Wood Fiber & $22.0 \mathrm{a}$ & $3.7 \mathrm{a}$ & $12.9 \mathrm{a}$ & $30.3 \mathrm{a}$ & $482.1 \mathrm{a}$ & $4.5 \mathrm{a}$ \\
\hline Peat & $22.3 \mathrm{a}$ & $4.0 \mathrm{a}$ & $11.8 \mathrm{a}$ & $29.6 \mathrm{a}$ & $446.9 \mathrm{a}$ & $4.6 \mathrm{a}$ \\
\hline Slot. Rice Hull & $19.1 \mathrm{a}$ & $3.3 \mathrm{a}$ & $13.5 \mathrm{a}$ & $27.4 \mathrm{a}$ & $428.4 \mathrm{a}$ & $3.6 \mathrm{a}$ \\
\hline PLA Bioplastic & $17.9 \mathrm{a}$ & $2.9 \mathrm{a}$ & $12.3 \mathrm{a}$ & $25.7 \mathrm{a}$ & $440.2 \mathrm{a}$ & $3.7 \mathrm{a}$ \\
\hline PHA Bioplastic & $24.4 \mathrm{a}$ & $4.0 \mathrm{a}$ & $13.6 \mathrm{a}$ & $28.5 \mathrm{a}$ & $514.8 \mathrm{a}$ & $4.7 \mathrm{a}$ \\
\hline Solid Rice Hull & $21.7 \mathrm{a}$ & $4.0 \mathrm{a}$ & $14.1 \mathrm{a}$ & $28.3 \mathrm{a}$ & $496.5 \mathrm{a}$ & $4.3 \mathrm{a}$ \\
\hline Straw & $17.8 \mathrm{a}$ & $3.3 \mathrm{a}$ & $12.4 \mathrm{a}$ & $29.3 \mathrm{a}$ & $379.9 \mathrm{a}$ & $4.6 \mathrm{a}$ \\
\hline Plastic & $19.2 \mathrm{a}$ & $3.2 \mathrm{a}$ & $13.5 \mathrm{a}$ & $28.4 \mathrm{a}$ & $438.2 \mathrm{a}$ & $3.7 \mathrm{a}$ \\
\hline$P$ value & 0.028 & 0.416 & 0.156 & 0.095 & 0.591 & 0.018 \\
\hline
\end{tabular}

Experimental units were replicated three times. Statistical analysis using ANOVA with Holm-Sidak

method was used to indicate if treatments were different from other treatments (as indicated by lower case letters).

All measurements were taken at the end of the ten week experiment.

${ }^{\mathrm{z}}$ Means in a column followed by different letters are significantly different at the $P \leq 0.05$ level, Holm-Sidak method.

${ }^{\mathrm{y}}$ Data passed Normality Test (Shapiro Wilk) and Equal Variance Test.

${ }^{\mathrm{x}}$ Data passed Equal Variance Test, but failed Normality Test (Shapiro Wilk).

${ }^{\mathrm{w}}$ Data failed Normality Test (Shapiro Wilk) and Equal Variance Test. 
Table 2.4. Final plant growth of Impatiens spp. 'Sunpatiens Compact' grown in a greenhouse for six weeks in 2012 using biodegradable plant pots.

\begin{tabular}{|c|c|c|c|c|c|}
\hline Container Type & Fresh Wt $(\mathrm{g})^{\mathrm{yz}}$ & Dry Wt. (g) ${ }^{\mathrm{yz}}$ & $\begin{array}{l}\text { Final Width } \\
(\mathrm{cm})^{\mathrm{yz}}\end{array}$ & $\begin{array}{l}\text { Final Height } \\
(\mathrm{cm})^{\mathrm{yz}}\end{array}$ & $\begin{array}{c}\text { Final Area } \\
\left(\mathrm{cm}^{2}\right)^{\mathrm{wz}}\end{array}$ \\
\hline Coir & $56.9 \mathrm{e}$ & $3.6 \mathrm{bc}$ & $20.7 \mathrm{a}$ & $14.9 \mathrm{~b}$ & $666.6 \mathrm{a}$ \\
\hline Manure & $79.6 \mathrm{ab}$ & $4.7 \mathrm{ab}$ & $22.9 \mathrm{a}$ & $18.5 \mathrm{a}$ & 923.8 \\
\hline Wood Fiber & 68.0 bcde & $4.4 \mathrm{abc}$ & $21.6 \mathrm{a}$ & $17.4 \mathrm{ab}$ & $751.6 \mathrm{a}$ \\
\hline Peat & 65.2 bcde & $4.0 \mathrm{abc}$ & $21.7 \mathrm{a}$ & $17.8 \mathrm{ab}$ & $733.2 \mathrm{a}$ \\
\hline Slot. Rice Hull & $57.9 \mathrm{e}$ & $3.5 \mathrm{c}$ & $20.7 \mathrm{a}$ & $15.2 \mathrm{ab}$ & $698.4 \mathrm{a}$ \\
\hline PLA Bioplastic & $73.5 \mathrm{abcd}$ & $4.3 \mathrm{abc}$ & $21.3 \mathrm{a}$ & $16.4 \mathrm{ab}$ & $774.2 \mathrm{a}$ \\
\hline PHA Bioplastic & 86.1 a & $4.9 \mathrm{a}$ & $21.9 \mathrm{a}$ & $17.6 \mathrm{ab}$ & $911.5 \mathrm{a}$ \\
\hline Solid Rice Hull & $63.9 \mathrm{cde}$ & $4.0 \mathrm{abc}$ & $21.6 \mathrm{a}$ & $15.6 \mathrm{ab}$ & $781.0 \mathrm{a}$ \\
\hline Straw & $55.7 \mathrm{e}$ & $3.4 \mathrm{c}$ & $20.9 \mathrm{a}$ & $16.3 \mathrm{ab}$ & $676.8 \mathrm{a}$ \\
\hline Plastic & $76.3 \mathrm{abc}$ & $4.5 \mathrm{ab}$ & $22.5 \mathrm{a}$ & $16.8 \mathrm{ab}$ & $836.9 \mathrm{a}$ \\
\hline$P$ value & $<0.001$ & $<0.001$ & 0.096 & 0.015 & 0.040 \\
\hline
\end{tabular}

Experimental units were replicated three times. Statistical analysis using ANOVA with Holm-Sidak

method was used to indicate if treatments were different from other treatments (as indicated by lower case letters).

All measurements were taken at the end of thesix week experiment.

${ }^{\mathrm{z}}$ Means in a column followed by different letters are significantly different at the $P \leq 0.05$ level, Holm-Sidak methor

${ }^{\mathrm{y}}$ Data passed Normality Test (Shapiro Wilk) and Equal Variance Test.

${ }^{\mathrm{x}}$ Data passed Equal Variance Test, but failed Normality Test (Shapiro Wilk). 
Table 2.5. Final plant growth of Lavendula angustifolia 'Elegans Ice' grown in a greenhouse for twelve weeks in 2012 using biodegradable plant pots.

\begin{tabular}{|c|c|c|c|c|c|c|c|c|c|c|c|c|}
\hline \multirow{2}{*}{$\begin{array}{l}\text { Container Type } \\
\text { Coir }\end{array}$} & \multicolumn{2}{|c|}{ Fresh Wt $(\mathrm{g})^{\mathrm{yz}}$} & \multicolumn{2}{|c|}{ Dry Wt. $(g)^{\mathrm{yz}}$} & \multicolumn{2}{|c|}{$\begin{array}{l}\text { Final Width } \\
\qquad(\mathrm{cm})^{\mathrm{yz}}\end{array}$} & \multicolumn{2}{|c|}{$\begin{array}{l}\text { Final Height } \\
\qquad(\mathrm{cm})^{\mathrm{yz}}\end{array}$} & \multicolumn{2}{|c|}{$\begin{array}{l}\text { Final Area } \\
\left(\mathrm{cm}^{2}\right)^{\mathrm{yz}}\end{array}$} & \multicolumn{2}{|c|}{ Ranking $^{\mathrm{yz}}$} \\
\hline & 26.0 & $\mathrm{a}$ & 5.7 & $\mathrm{a}$ & 13.0 & $\mathrm{~b}$ & 22.6 & $\mathrm{a}$ & 451.0 & $\mathrm{a}$ & 3.9 & $\mathrm{a}$ \\
\hline Manure & 32.3 & $\mathrm{a}$ & 7.7 & $\mathrm{a}$ & 14.1 & $a b$ & 31.3 & $\mathrm{a}$ & 527.0 & $\mathrm{a}$ & 3.8 & $\mathrm{a}$ \\
\hline Wood Fiber & 32.1 & $\mathrm{a}$ & 7.8 & $\mathrm{a}$ & 14.8 & $a b$ & 29.2 & $\mathrm{a}$ & 545.1 & $\mathrm{a}$ & 3.7 & a \\
\hline Peat & 23.8 & $\mathrm{a}$ & 5.9 & $\mathrm{a}$ & 12.9 & $\mathrm{~b}$ & 29.6 & $\mathrm{a}$ & 531.1 & $\mathrm{a}$ & 3.9 & $\mathrm{a}$ \\
\hline Slot. Rice Hull & 29.5 & $\mathrm{a}$ & 6.6 & $\mathrm{a}$ & 15.5 & $a b$ & 26.7 & $\mathrm{a}$ & 572.0 & $\mathrm{a}$ & 3.6 & $\mathrm{a}$ \\
\hline PLA Bioplastic & 25.4 & $\mathrm{a}$ & 5.7 & $\mathrm{a}$ & 14.3 & $a b$ & 25.1 & $\mathrm{a}$ & 454.1 & $\mathrm{a}$ & 3.5 & $\mathrm{a}$ \\
\hline PHA Bioplastic & 32.3 & $\mathrm{a}$ & 7.2 & $\mathrm{a}$ & 15.0 & $a b$ & 28.7 & $\mathrm{a}$ & 534.8 & $\mathrm{a}$ & 3.8 & $\mathrm{a}$ \\
\hline Solid Rice Hull & 25.7 & $\mathrm{a}$ & 5.4 & $\mathrm{a}$ & 16.5 & $\mathrm{a}$ & 26.8 & $\mathrm{a}$ & 516.2 & $\mathrm{a}$ & 3.9 & $\mathrm{a}$ \\
\hline Straw & 32.2 & $\mathrm{a}$ & 7.4 & $\mathrm{a}$ & 15.1 & $a b$ & 28.3 & $\mathrm{a}$ & 551.5 & $\mathrm{a}$ & 4.0 & $\mathrm{a}$ \\
\hline Plastic & 28.5 & $\mathrm{a}$ & 6.0 & $\mathrm{a}$ & 14.6 & $a b$ & 24.4 & $\mathrm{a}$ & 515.1 & $\mathrm{a}$ & 3.8 & a \\
\hline $\mathrm{P}$ value & 0.26 & & 0.05 & & 0.02 & & 0.03 & & 0.47 & & 0.93 & \\
\hline
\end{tabular}

Experimental units were replicated three times. Statistical analysis using ANOVA with Holm-Sidak

method was used to indicate if treatments were different from other treatments (as indicated by lower case letters).

All measurements were taken at the end of the twelve week experiment.

${ }^{\mathrm{z}}$ Means in a column followed by different letters are significantly different at the $P \leq 0.05$ level, Holm-Sidak method.

${ }^{\mathrm{y}}$ Data passed Normality Test (Shapiro Wilk) and Equal Variance Test. 
Table 2.6. Leachate $\mathrm{pH}$ of media in biodegradable pots used to grow Impatiens spp. 'Sunpatiens Compact' in $2011^{\mathrm{x}}$.

\begin{tabular}{lcccl}
\hline Container Type & $\begin{array}{c}\text { Week } 0 \\
\mathrm{~b}^{\mathrm{yz}}\end{array}$ & $\begin{array}{c}\text { Week } 2 \\
\mathrm{a}^{\text {yz }}\end{array}$ & $\begin{array}{c}\text { Week } 4 \\
\mathrm{c}^{\mathrm{yz}}\end{array}$ & $\begin{array}{c}\text { Week 6 } \\
\mathrm{d}^{\mathrm{yz}}\end{array}$ \\
\hline Coir & $6.6 \mathrm{~cd}$ & $6.6 \mathrm{de}$ & $6.4 \mathrm{bc}$ & $6.1 \mathrm{ab}$ \\
Manure & $7.4 \mathrm{a}$ & $7.5 \mathrm{a}$ & $6.9 \mathrm{a}$ & $6.4 \mathrm{a}$ \\
Wood Fiber & $6.9 \mathrm{bc}$ & $7.1 \mathrm{abc}$ & $6.2 \mathrm{bc}$ & $5.7 \mathrm{bcd}$ \\
Peat & $6.2 \mathrm{~d}$ & $6.5 \mathrm{e}$ & $6.0 \mathrm{c}$ & $5.2 \mathrm{e}$ \\
Slot. Rice Hull & $7.3 \mathrm{ab}$ & $7.3 \mathrm{ab}$ & $6.6 \mathrm{ab}$ & $6.0 \mathrm{abc}$ \\
PLA Bioplastic & $6.6 \mathrm{~cd}$ & $6.8 \mathrm{cde}$ & $6.2 \mathrm{bc}$ & $5.4 \mathrm{de}$ \\
PHA Bioplastic & $6.5 \mathrm{~cd}$ & $6.7 \mathrm{de}$ & $6.4 \mathrm{abc}$ & $6.1 \mathrm{ab}$ \\
Solid Rice Hull & $6.6 \mathrm{~cd}$ & $6.7 \mathrm{de}$ & $6.2 \mathrm{bc}$ & $5.4 \mathrm{de}$ \\
Straw & $6.9 \mathrm{bc}$ & $7.0 \mathrm{~cd}$ & $6.5 \mathrm{ab}$ & $6.3 \mathrm{a}$ \\
\hline Plastic & $6.5 \mathrm{~d}$ & $6.6 \mathrm{de}$ & $6.2 \mathrm{bc}$ & $5.6 \mathrm{~cd}$
\end{tabular}

$\begin{array}{ll}\text { ANOVA } & \\ \text { Pot } & <0.001 \\ \text { Week } & <0.001 \\ \text { Pot vs. Week } & <0.001\end{array}$

Values are means of three experimental units replicated over time. Statistical analysis using ANOVA with Tukey's Test or Holm-Sidak used to indicate if treatments were different from other treatments.

Biweekly leachate $\mathrm{pH}$ measurements were taken using the pour-thru method.

${ }^{\mathrm{z}}$ Means in a column followed by different letters are significantly different at the $P \leq 0.05$ level, Tukey Test.

${ }^{\mathrm{y}}$ Treatments in a row followed by different letters are significantly different at the $P \leq 0.05$ level, Holm-Sidak method.

${ }^{\mathrm{x}}$ Data for $\mathrm{pH}$ in 2011 passed Equal Variance Test and Normality Test (Shapiro Wilk). 
Table 2.7. Leachate $\mathrm{pH}$ of media in biodegradable pots used to grow Lavendula angustifolia 'Elegans Ice' in 2011 ${ }^{\mathrm{x}}$.

\begin{tabular}{lccccccc}
\hline Container Type & Week & Week 2 & Week 4 & Week 6 & Week 8 & \multicolumn{2}{l}{ Week 10 } \\
& $\mathrm{a}^{\mathrm{yz}}$ & $\mathrm{a}^{\mathrm{z}}$ & $\mathrm{a}^{\mathrm{z}}$ & $\mathrm{b}^{\mathrm{z}}$ & $\mathrm{c}^{\mathrm{z}}$ & $\mathrm{d}^{\mathrm{z}}$ & \\
\hline Coir & $6.3 \mathrm{~d}$ & $6.5 \mathrm{c}$ & $6.5 \mathrm{cde}$ & $6.2 \mathrm{bc}$ & $6.3 \mathrm{bc}$ & $6.1 \mathrm{abc}$ \\
Manure & $7.6 \mathrm{a}$ & $7.3 \mathrm{a}$ & $7.4 \mathrm{a}$ & $7.2 \mathrm{a}$ & $6.9 \mathrm{a}$ & $6.5 \mathrm{a}$ \\
Wood Fiber & $6.8 \mathrm{~b}$ & $7.0 \mathrm{ab}$ & $7.0 \mathrm{~b}$ & $6.3 \mathrm{bc}$ & $6.1 \mathrm{bcd}$ & $6.0 \mathrm{bcde}$ \\
Peat & $6.5 \mathrm{~cd}$ & $6.5 \mathrm{c}$ & $6.3 \mathrm{e}$ & $6.0 \mathrm{c}$ & $5.7 \mathrm{~d}$ & $5.7 \mathrm{e}$ \\
Slot. Rice Hull & $7.0 \mathrm{~b}$ & $7.3 \mathrm{a}$ & $7.4 \mathrm{a}$ & $7.1 \mathrm{a}$ & $6.4 \mathrm{~b}$ & $6.3 \mathrm{ab}$ \\
PLA Bioplastic & $6.4 \mathrm{~cd}$ & $6.4 \mathrm{c}$ & $6.4 \mathrm{de}$ & $6.2 \mathrm{bc}$ & $6.0 \mathrm{bcd}$ & $5.8 \mathrm{cde}$ \\
PHA Bioplastic & $6.5 \mathrm{~cd}$ & $6.4 \mathrm{c}$ & $6.6 \mathrm{bcde}$ & $6.3 \mathrm{bc}$ & $6.3 \mathrm{~b}$ & $6.1 \mathrm{bcd}$ \\
Solid Rice Hull & $6.4 \mathrm{~cd}$ & $6.5 \mathrm{c}$ & $6.7 \mathrm{bcd}$ & $6.3 \mathrm{bc}$ & $5.9 \mathrm{~cd}$ & $5.7 \mathrm{de}$ \\
Straw & $6.7 \mathrm{~d}$ & $6.8 \mathrm{bc}$ & $6.8 \mathrm{bc}$ & $6.4 \mathrm{~b}$ & $6.4 \mathrm{~b}$ & $6.3 \mathrm{ab}$
\end{tabular}

$\begin{array}{ll}\text { ANOVA } & \\ \text { Pot } & <0.001 \\ \text { Week } & <0.001 \\ \text { Pot vs. Week } & <0.001\end{array}$

Values are means of three experimental units replicated over time. Statistical analysis using ANOVA with Tukey's Test or Holm-Sidak used to indicate if treatments were different from other treatments.

Biweekly leachate $\mathrm{pH}$ measurements were taken using the pour-thru method.

${ }^{\mathrm{z}}$ Means in a column followed by different letters are significantly different at the $P \leq 0.05$ level, Tukey Test.

${ }^{\mathrm{y}}$ Treatments in a row followed by different letters are significantly different at the $P \leq 0.05$ level, Holm-Sidak method.

${ }^{\mathrm{x}}$ Data for $\mathrm{pH}$ in 2011 passed Equal Variance Test and Normality Test (Shapiro Wilk). 
Table 2.8. Leachate $\mathrm{pH}$ of media in biodegradable pots used to grow Impatiens spp . 'Sunpatiens Compact' in $2012^{\mathrm{x}}$.

\begin{tabular}{llccl}
\hline Container Type & $\begin{array}{c}\text { Week } 0 \\
\mathrm{a}^{\mathrm{yz}}\end{array}$ & $\begin{array}{c}\text { Week } 2 \\
\mathrm{bc}^{\mathrm{z}}\end{array}$ & $\begin{array}{c}\text { Week } 4 \\
\mathrm{c}^{\mathrm{z}}\end{array}$ & $\begin{array}{c}\text { Week } 6 \\
\mathrm{~b}^{\mathrm{z}}\end{array}$ \\
\hline Coir & $6.3 \mathrm{e}$ & $6.2 \mathrm{abc}$ & $6.3 \mathrm{bcd}$ & $6.7 \mathrm{abcd}$ \\
Manure & $7.0 \mathrm{ab}$ & $6.6 \mathrm{ab}$ & $7.2 \mathrm{a}$ & $7.1 \mathrm{a}$ \\
Wood Fiber & $6.9 \mathrm{abcd}$ & $6.2 \mathrm{bc}$ & $6.0 \mathrm{cde}$ & $6.3 \mathrm{bcd}$ \\
Peat & $5.6 \mathrm{f}$ & $6.1 \mathrm{bc}$ & $5.3 \mathrm{f}$ & $5.7 \mathrm{ef}$ \\
Slot. Rice Hull & $7.1 \mathrm{a}$ & $6.6 \mathrm{ab}$ & $6.5 \mathrm{bc}$ & $6.7 \mathrm{abc}$ \\
PLA Bioplastic & $6.9 \mathrm{abc}$ & $6.0 \mathrm{c}$ & $6.0 \mathrm{cde}$ & $6.3 \mathrm{cde}$ \\
PHA Bioplastic & $6.4 \mathrm{de}$ & $6.7 \mathrm{a}$ & $6.7 \mathrm{~b}$ & $6.7 \mathrm{abcd}$ \\
Solid Rice Hull & $6.6 \mathrm{bcde}$ & $6.1 \mathrm{bc}$ & $5.7 \mathrm{ef}$ & $5.7 \mathrm{f}$ \\
Straw & $6.7 \mathrm{abcd}$ & $6.5 \mathrm{ab}$ & $6.5 \mathrm{bc}$ & $6.8 \mathrm{ab}$ \\
\hline Plastic & $6.5 \mathrm{cde}$ & $6.0 \mathrm{c}$ & $5.8 \mathrm{de}$ & $6.2 \mathrm{def}$
\end{tabular}

$\begin{array}{ll}\text { ANOVA } & \\ \text { Pot } & <0.001 \\ \text { Week } & <0.001 \\ \text { Pot vs. Week } & <0.001\end{array}$

Values are means of three experimental units replicated over time. Statistical analysis using ANOVA with Tukey's Test or Holm-Sidak used to indicate if treatments were different from other treatments.

Biweekly leachate $\mathrm{pH}$ measurements were taken using the pour-thru method.

${ }^{\mathrm{z}}$ Means in a column followed by different letters are significantly different at the $P \leq 0.05$ level, Tukey Test.

${ }^{\mathrm{y}}$ Treatments in a row followed by different letters are significantly different at the $P \leq 0.05$ level, Holm-Sidak method.

${ }^{\mathrm{x}}$ Data for $\mathrm{pH}$ in 2012 passed Equal Variance Test and Normality Test (Shapiro Wilk). 
Table 2.9. Leachate $\mathrm{pH}$ of media in biodegradable pots used to grow Lavendula angustifolia 'Elegans Ice' in 2012 .

\begin{tabular}{lccccccc}
\hline Container Type & $\begin{array}{c}\text { Week } 0 \\
\mathrm{ab}^{\mathrm{yz}}\end{array}$ & $\begin{array}{c}\text { Week 2 } \\
\mathrm{ab}^{\mathrm{z}}\end{array}$ & $\begin{array}{c}\text { Week } 4 \\
\mathrm{c}^{\mathrm{z}}\end{array}$ & $\begin{array}{c}\text { Week 6 } \\
\mathrm{d}^{\mathrm{z}}\end{array}$ & $\begin{array}{c}\text { Week } 8 \\
\mathrm{bc}^{\mathrm{z}}\end{array}$ & $\begin{array}{c}\text { Week 10 } \\
\mathrm{d}^{\mathrm{z}}\end{array}$ & $\begin{array}{c}\text { Week 12 } \\
\mathrm{a}^{\mathrm{z}}\end{array}$ \\
\hline Coir & $6.49 \mathrm{a}$ & $6.76 \mathrm{ab}$ & $6.4 \mathrm{bc}$ & $6.37 \mathrm{abc}$ & $6.74 \mathrm{abcd}$ & $6.32 \mathrm{abc}$ & $6.94 \mathrm{ab}$ \\
Manure & $6.98 \mathrm{a}$ & $6.99 \mathrm{a}$ & $7.54 \mathrm{a}$ & $6.96 \mathrm{a}$ & $7.37 \mathrm{a}$ & $6.62 \mathrm{a}$ & $7.2 \mathrm{a}$ \\
Wood Fiber & $6.59 \mathrm{a}$ & $6.83 \mathrm{ab}$ & $5.87 \mathrm{~cd}$ & $5.6 \mathrm{de}$ & $6.05 \mathrm{de}$ & $5.69 \mathrm{bcd}$ & $6.59 \mathrm{abc}$ \\
Peat & $6.41 \mathrm{a}$ & $6.66 \mathrm{ab}$ & $5.54 \mathrm{~d}$ & $7.09 \mathrm{e}$ & $6.71 \mathrm{e}$ & $6.58 \mathrm{~d}$ & $6.25 \mathrm{c}$ \\
Slot. Rice Hull & $7.09 \mathrm{a}$ & $7.02 \mathrm{a}$ & $6.71 \mathrm{~b}$ & $6.58 \mathrm{ab}$ & $7.02 \mathrm{ab}$ & $6.07 \mathrm{abcd}$ & $7.24 \mathrm{a}$ \\
PLA Bioplastic & $6.48 \mathrm{a}$ & $6.23 \mathrm{~b}$ & $6.27 \mathrm{bc}$ & $5.98 \mathrm{bcde}$ & $6.08 \mathrm{de}$ & $5.62 \mathrm{~cd}$ & $6.61 \mathrm{abc}$ \\
PHA Bioplastic & $6.46 \mathrm{a}$ & $6.74 \mathrm{ab}$ & $6.87 \mathrm{ab}$ & $6.55 \mathrm{ab}$ & $6.9 \mathrm{abc}$ & $6.6 \mathrm{a}$ & $6.95 \mathrm{ab}$ \\
Solid Rice Hull & $6.49 \mathrm{a}$ & $6.24 \mathrm{~b}$ & $5.9 \mathrm{~cd}$ & $5.89 \mathrm{bcde}$ & $6.45 \mathrm{bcde}$ & $5.52 \mathrm{~d}$ & $6.4 \mathrm{bc}$ \\
Straw & $6.59 \mathrm{a}$ & $6.82 \mathrm{ab}$ & $6.48 \mathrm{bc}$ & $6.3 \mathrm{abcd}$ & $6.57 \mathrm{bcd}$ & $6.37 \mathrm{ab}$ & $7.1 \mathrm{a}$ \\
\hline Plastic & $6.39 \mathrm{a}$ & $6.24 \mathrm{~b}$ & $6.28 \mathrm{bc}$ & $5.74 \mathrm{cde}$ & $6.2 \mathrm{cde}$ & $5.89 \mathrm{bcd}$ & $6.36 \mathrm{bc}$
\end{tabular}

\section{ANOVA}

$\begin{array}{ll}\text { Pot } & <0.001 \\ \text { Week } & <0.001 \\ \text { Pot vs. Week } & <0.001\end{array}$

Values are means of three experimental units replicated over time. Statistical analysis using ANOVA with Tukey's Test or Holm-Sidak used to indicate if treatments were different from other treatments.

Biweekly leachate $\mathrm{pH}$ measurements were taken using the pour-thru method.

${ }^{\mathrm{z}}$ Means in a column followed by different letters are significantly different at the $P \leq 0.05$ level, Tukey Test.

${ }^{\mathrm{y}}$ Treatments in a row followed by different letters are significantly different at the $P \leq 0.05$ level, Holm-Sidak method.

${ }^{\mathrm{x}}$ Data for $\mathrm{pH}$ in 2012 passed Equal Variance Test and Normality Test (Shapiro Wilk). 


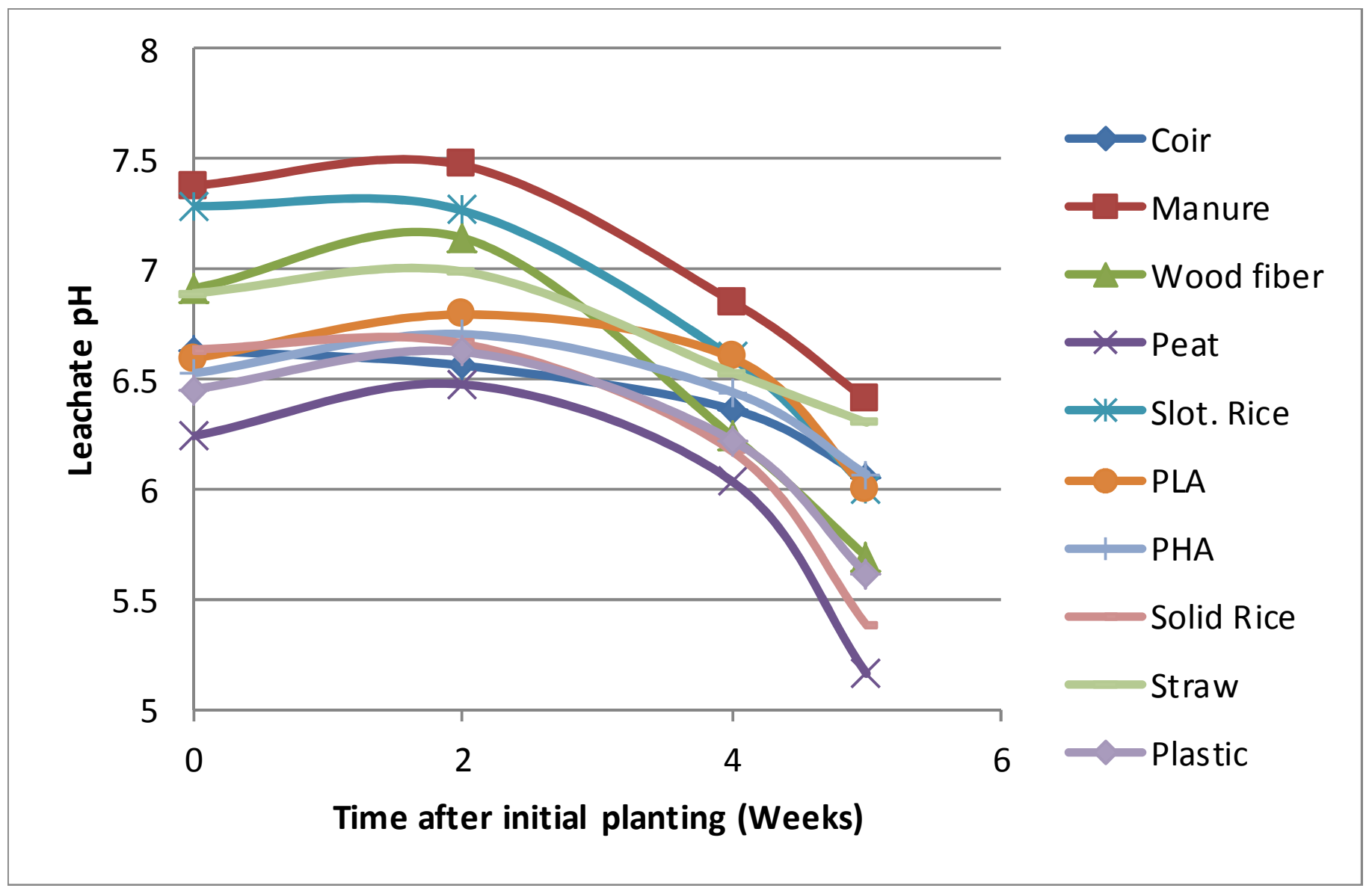

Figure 2.4. Leachate pH of media in biodegradable pots used to grow Impatiens spp. 'Sunpatiens Compact' in 2011. Values are means of three experimental units replicated over time. Statistical analysis using ANOVA with Tukey's Test or Holm-Sidak used to indicate if treatments were different from other treatments. Biweekly leachate $\mathrm{pH}$ measurements were taken using the pour-thru method. 


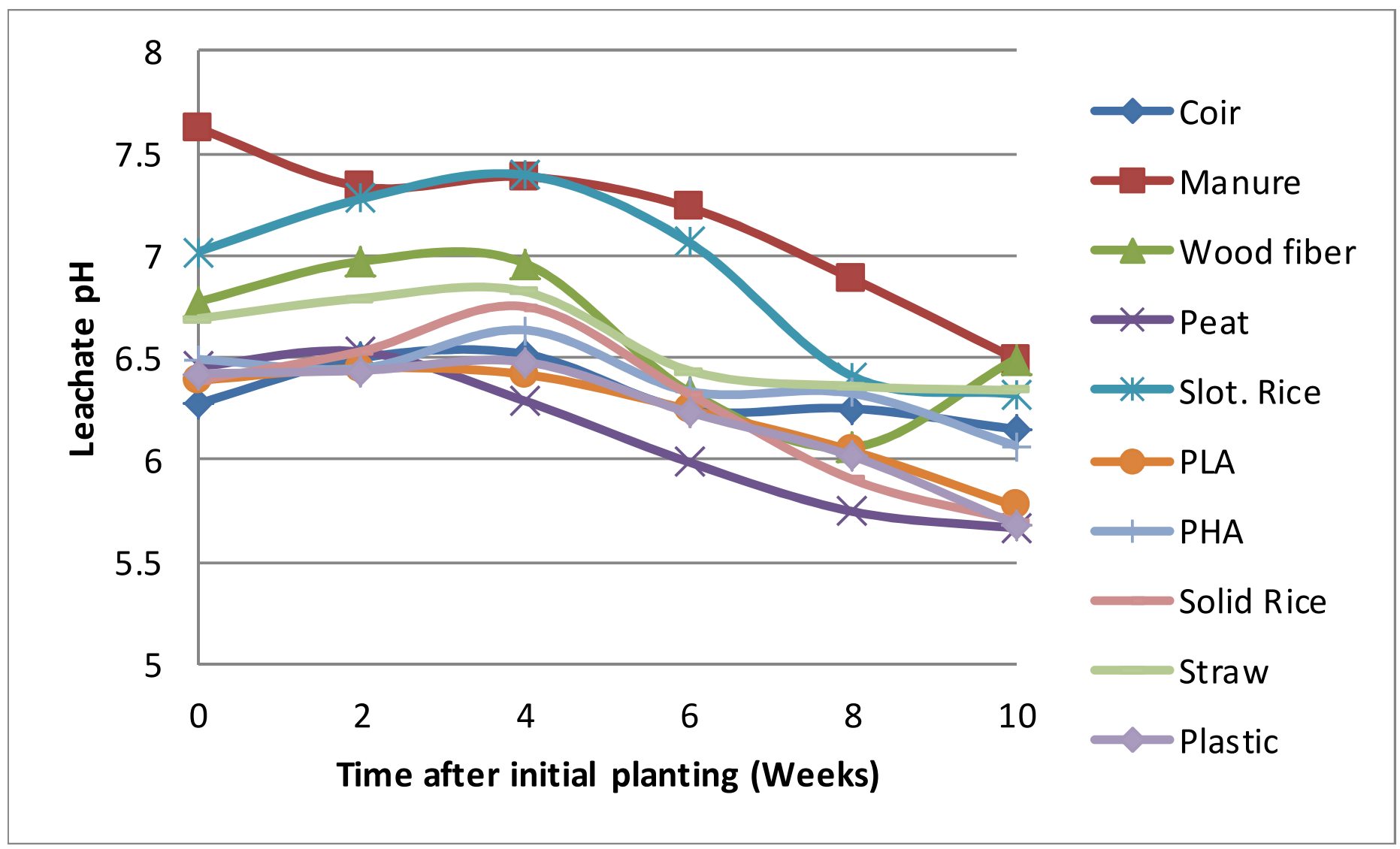

Figure 2.5. Leachate $\mathrm{pH}$ of media in biodegradable pots used to grow Lavendula angustifolia 'Elegans Ice' in 2011. Values are means of three experimental units replicated over time. Statistical analysis using ANOVA with Tukey's Test or Holm-Sidak used to indicate if treatments were different from other treatments. Biweekly leachate $\mathrm{pH}$ measurements were taken using the pour-thru method. 


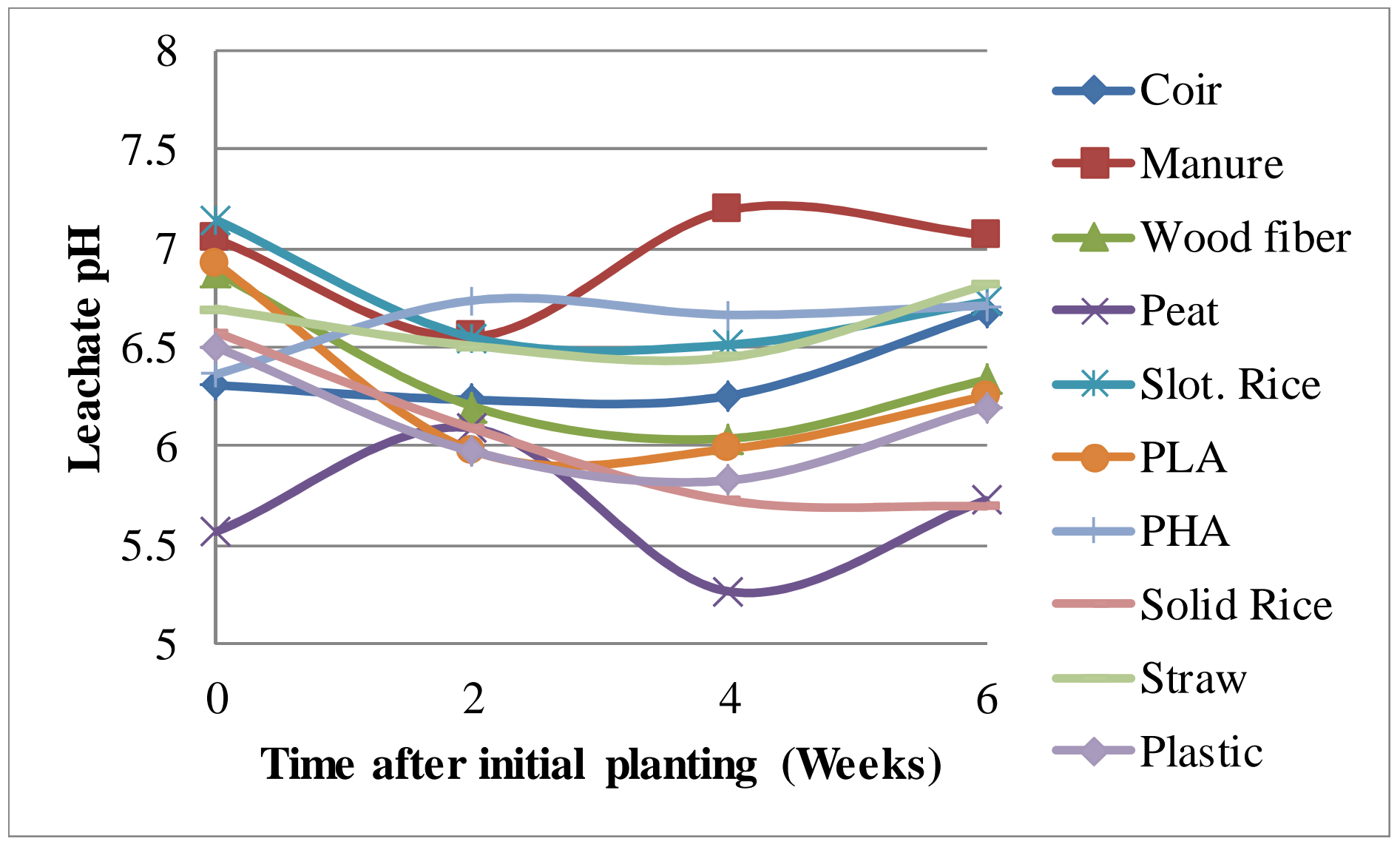

Figure 2.6. Leachate $\mathrm{pH}$ of media in biodegradable pots used to grow Impatiens spp. 'Sunpatiens Compact' in $2012^{\mathrm{x}}$. Values are means of three experimental units replicated over time. Statistical analysis using ANOVA with Tukey's Test or Holm-Sidak used to indicate if treatments were different from other treatments. Biweekly leachate $\mathrm{pH}$ measurements were taken using the pour-thru method. 


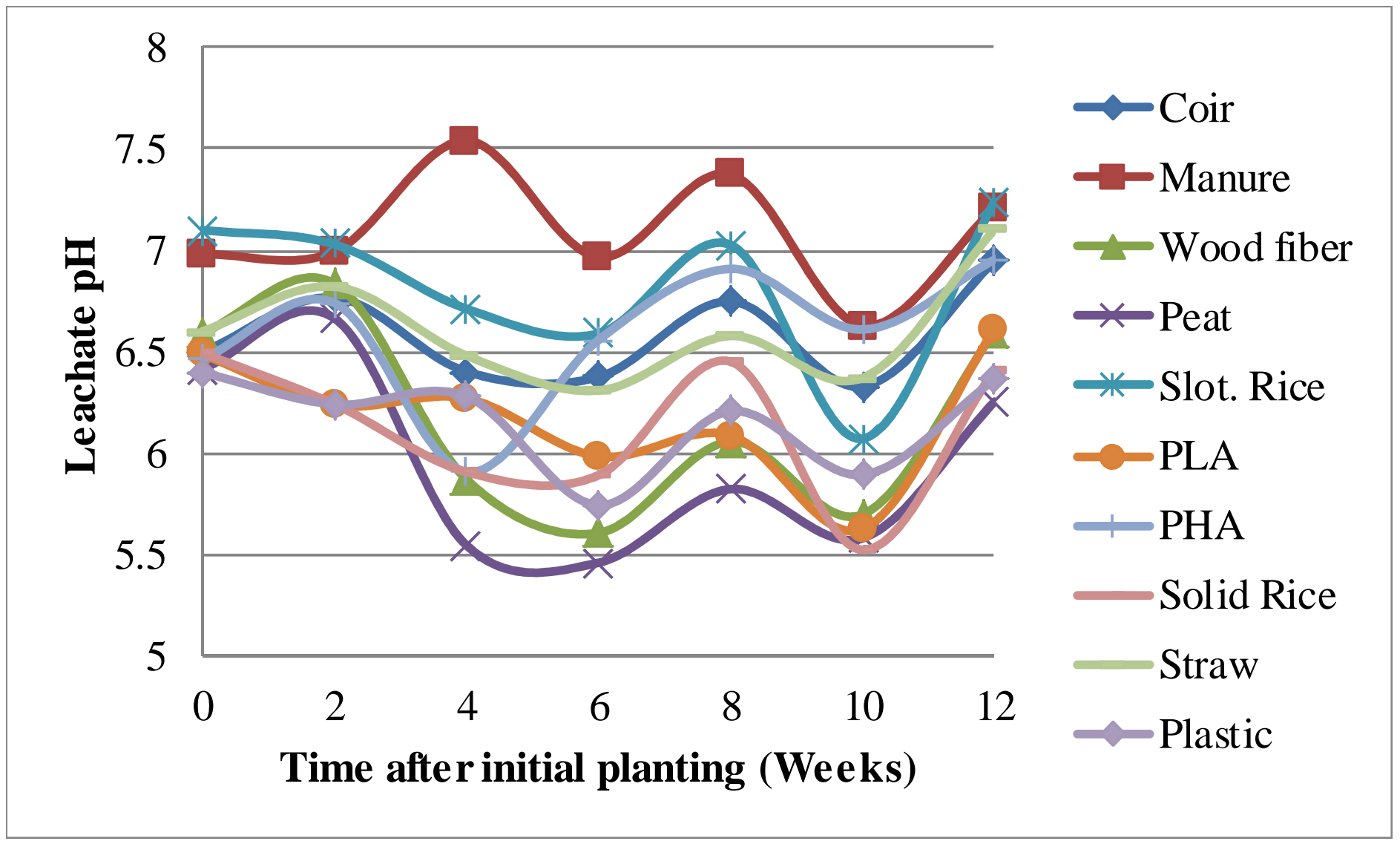

Figure 2.7. Leachate $\mathrm{pH}$ of media in biodegradable pots used to grow Lavendula angustifolia 'Elegans Ice' in 2012. Values are means of three experimental units replicated over time. Statistical analysis using ANOVA with Tukey's Test or Holm-Sidak used to indicate if treatments were different from other treatments. Biweekly leachate $\mathrm{pH}$ measurements were taken using the pour-thru method. 
Table 2.10. Leachate EC (mS/cm) of media in biodegradable pots used to grow Impatiens spp. 'Sunpatiens Compact' in $2011^{\mathrm{x}}$.

\begin{tabular}{lcccc}
\hline Container Type & $\begin{array}{c}\text { Week } 0 \\
\mathrm{~b}^{\mathrm{yz}}\end{array}$ & $\begin{array}{c}\text { Week } 2 \\
\mathrm{~d}^{\mathrm{z}}\end{array}$ & $\begin{array}{c}\text { Week } 4 \\
\mathrm{c}^{\mathrm{z}}\end{array}$ & $\begin{array}{c}\text { Week 6 } \\
\mathrm{a}^{\mathrm{z}}\end{array}$ \\
\hline Coir & $1971.2 \mathrm{a}$ & $1219.0 \mathrm{a}$ & $1372.6 \mathrm{a}$ & $1643.4 \mathrm{abc}$ \\
Manure & $1733.1 \mathrm{ab}$ & $1170.1 \mathrm{a}$ & $1471.3 \mathrm{a}$ & $2195.3 \mathrm{a}$ \\
Wood Fiber & $1243.3 \mathrm{ab}$ & $574.1 \mathrm{a}$ & $1659.1 \mathrm{a}$ & $2223.5 \mathrm{a}$ \\
Peat & $1157.7 \mathrm{~b}$ & $655.2 \mathrm{a}$ & $1422.9 \mathrm{a}$ & $2183.8 \mathrm{a}$ \\
Slot. Rice Hull & $1929.8 \mathrm{a}$ & $1122.7 \mathrm{a}$ & $1486.3 \mathrm{a}$ & $1978.3 \mathrm{ab}$ \\
PLA Bioplastic & $1400.9 \mathrm{ab}$ & $957.7 \mathrm{a}$ & $1415.0 \mathrm{a}$ & $1876.9 \mathrm{ab}$ \\
PHA Bioplastic & $1542.6 \mathrm{ab}$ & $951.4 \mathrm{a}$ & $1107.0 \mathrm{a}$ & $1493.8 \mathrm{abc}$ \\
Solid Rice Hull & $1636.5 \mathrm{ab}$ & $822.2 \mathrm{a}$ & $1393.7 \mathrm{a}$ & $1662.7 \mathrm{abc}$ \\
Straw & $1513.9 \mathrm{ab}$ & $972.3 \mathrm{a}$ & $1230.7 \mathrm{a}$ & $1400.3 \mathrm{bc}$ \\
\hline Plastic & $1587.1 \mathrm{ab}$ & $907.9 \mathrm{a}$ & $1259.2 \mathrm{a}$ & $1113.6 \mathrm{c}$
\end{tabular}

$\begin{array}{ll}\text { ANOVA } & \\ \text { Pot } & <0.001 \\ \text { Week } & <0.001 \\ \text { Pot vs. Week } & 0.001\end{array}$

Values are means of three experimental units replicated over time. Statistical analysis using ANOVA with Tukey's Test or Holm-Sidak used to indicate if treatments were different from other treatments.

Biweekly leachate EC measurements were taken using the pour-thru method.

${ }^{\mathrm{z}}$ Means in a column followed by different letters are significantly different at the $P \leq 0.05$ level, Tukey Test.

${ }^{\mathrm{y}}$ Treatments in a row followed by different letters are significantly different at the $P \leq 0.05$ level, Holm-Sidak method.

${ }^{\mathrm{x}}$ Data for EC in 2011 passed Equal Variance Test and Normality Test (Shapiro Wilk). 
Table 2.11. Leachate EC $(\mathrm{mS} / \mathrm{cm})$ of media in biodegradable pots used to grow Lavendula angustifolia 'Elegans Ice' in $2011^{\mathrm{x}}$.

\begin{tabular}{|c|c|c|c|c|c|c|}
\hline Container Type & $\begin{array}{c}\text { Week 0 } \\
\mathrm{c}^{\mathrm{yz}}\end{array}$ & $\begin{array}{c}\text { Week } 2 \\
\mathrm{~d}^{\mathrm{z}} \\
\end{array}$ & $\begin{array}{c}\text { Week } 4 \\
\mathrm{~d}^{\mathrm{z}} \\
\end{array}$ & $\begin{array}{c}\text { Week } 6 \\
b^{\mathrm{z}}\end{array}$ & $\begin{array}{c}\text { Week } 8 \\
\mathrm{a}^{\mathrm{z}} \\
\end{array}$ & $\begin{array}{c}\text { Week } 10 \\
\mathrm{a}^{\mathrm{z}} \\
\end{array}$ \\
\hline Coir & $2668.7 \mathrm{a}$ & $1793.5 \mathrm{a}$ & $1575.5 \mathrm{a}$ & $2491.4 \mathrm{a}$ & $2723.6 \mathrm{a}$ & $2538.5 \mathrm{abc}$ \\
\hline Manure & $2123.1 \mathrm{ab}$ & $1385.2 \mathrm{ab}$ & $933.7 \mathrm{a}$ & $1315.8 \mathrm{~b}$ & $1934.2 \mathrm{ab}$ & $2920.1 \mathrm{ab}$ \\
\hline Wood Fiber & $1234.3 \mathrm{bc}$ & 781.6 b & $1006.0 \mathrm{a}$ & $1952.7 \mathrm{ab}$ & $2238.5 \mathrm{ab}$ & $2291.4 \mathrm{abc}$ \\
\hline Peat & $778.9 \mathrm{c}$ & $619.3 \mathrm{~b}$ & $1074.2 \mathrm{a}$ & $1551.7 \mathrm{ab}$ & $2244.8 \mathrm{ab}$ & $2276.1 \mathrm{abc}$ \\
\hline Slot. Rice Hull & $1842.4 \mathrm{ab}$ & $1520.8 \mathrm{ab}$ & $1278.1 \mathrm{a}$ & $2079.1 \mathrm{ab}$ & $2574.2 \mathrm{ab}$ & 2068.9 bc \\
\hline PLA Bioplastic & $1554.0 \mathrm{bc}$ & $1118.4 \mathrm{ab}$ & $1399.7 \mathrm{a}$ & $1781.0 \mathrm{ab}$ & $2309.5 \mathrm{ab}$ & $1967.3 \mathrm{bc}$ \\
\hline PHA Bioplastic & $1183.3 \mathrm{bc}$ & $992.7 \mathrm{ab}$ & $965.4 \mathrm{a}$ & $1718.3 \mathrm{ab}$ & $1667.1 \mathrm{~b}$ & $1785.1 \mathrm{c}$ \\
\hline Solid Rice Hull & $1924.4 \mathrm{ab}$ & $1410.9 \mathrm{ab}$ & $1343.5 \mathrm{a}$ & $2296.6 \mathrm{a}$ & $2416.3 \mathrm{ab}$ & $3181.5 \mathrm{a}$ \\
\hline Straw & $1556.6 \mathrm{bc}$ & $987.4 \mathrm{ab}$ & $1094.7 \mathrm{a}$ & $1655.3 \mathrm{ab}$ & $2083.6 \mathrm{ab}$ & $2098.9 \mathrm{bc}$ \\
\hline Plastic & $1541.7 \mathrm{bc}$ & $967.7 \mathrm{ab}$ & $1335.2 \mathrm{a}$ & $1857.3 \mathrm{ab}$ & $2148.0 \mathrm{ab}$ & $2163.2 \mathrm{abc}$ \\
\hline
\end{tabular}

$\begin{array}{ll}\text { ANOVA } & \\ \text { Pot } & <0.001 \\ \text { Week } & <0.001 \\ \text { Pot vs. Week } & 0.018\end{array}$

Values are means of three experimental units replicated over time. Statistical analysis using ANOVA with Tukey's Test or Holm-Sidak used to indicate if treatments were different from other treatments.

Biweekly leachate EC measurements were taken using the pour-thru method.

${ }^{\mathrm{z}}$ Means in a column followed by different letters are significantly different at the $P \leq 0.05$ level, Tukey Test.

${ }^{\mathrm{y}}$ Treatments in a row followed by different letters are significantly different at the $P \leq 0.05$ level, Holm-Sidak method.

${ }^{\mathrm{x}}$ Data for EC in 2011 passed Equal Variance Test and Normality Test (Shapiro Wilk). 
Table 2.12. Leachate EC $(\mathrm{mS} / \mathrm{cm})$ of media in biodegradable pots used to grow Impatiens spp. 'Sunpatiens Compact' in $2012^{\mathrm{x}}$.

\begin{tabular}{lcccc}
\hline Container Type & $\begin{array}{c}\text { Week } 0 \\
\mathrm{a}^{\mathrm{yz}}\end{array}$ & $\begin{array}{c}\text { Week } 2 \\
\mathrm{~b}^{\mathrm{z}}\end{array}$ & $\begin{array}{c}\text { Week } 4 \\
\mathrm{~b}^{\mathrm{z}}\end{array}$ & $\begin{array}{c}\text { Week } 6 \\
\mathrm{c}^{\mathrm{z}}\end{array}$ \\
\hline Coir & $2607.4 \mathrm{a}$ & $2017.8 \mathrm{a}$ & $2013.8 \mathrm{a}$ & $1558.7 \mathrm{a}$ \\
Manure & $2021.3 \mathrm{a}$ & $1532.1 \mathrm{a}$ & $1572.2 \mathrm{a}$ & $1940.2 \mathrm{a}$ \\
Wood Fiber & $1891.6 \mathrm{a}$ & $2053.1 \mathrm{a}$ & $1999.3 \mathrm{a}$ & $1571.9 \mathrm{a}$ \\
Peat & $2035.8 \mathrm{a}$ & $1931.1 \mathrm{a}$ & $2103.4 \mathrm{a}$ & $1527.3 \mathrm{a}$ \\
Slot. Rice Hull & $2656.6 \mathrm{a}$ & $1985.4 \mathrm{a}$ & $1640.5 \mathrm{a}$ & $1776.4 \mathrm{a}$ \\
PLA Bioplastic & $2187.4 \mathrm{a}$ & $1681.1 \mathrm{a}$ & $1304.7 \mathrm{a}$ & $1152.0 \mathrm{a}$ \\
PHA Bioplastic & $1738.6 \mathrm{a}$ & $1248.3 \mathrm{a}$ & $1206.0 \mathrm{a}$ & $1231.7 \mathrm{a}$ \\
Solid Rice Hull & $2369.1 \mathrm{a}$ & $1604.2 \mathrm{a}$ & $1751.0 \mathrm{a}$ & $1330.5 \mathrm{a}$ \\
Straw & $2063.4 \mathrm{a}$ & $1538.2 \mathrm{a}$ & $1495.4 \mathrm{a}$ & $1245.2 \mathrm{a}$ \\
\hline Plastic & $2484.4 \mathrm{a}$ & $1934.9 \mathrm{a}$ & $1627.9 \mathrm{a}$ & $1254.7 \mathrm{a}$
\end{tabular}

$\begin{array}{ll}\text { ANOVA } & \\ \text { Pot } & <0.001 \\ \text { Week } & <0.001 \\ \text { Pot vs. Week } & 0.085\end{array}$

Values are means of three experimental units replicated over time. Statistical analysis using ANOVA with Tukey's Test or Holm-Sidak used to indicate if treatments were different from other treatments.

Biweekly leachate EC measurements were taken using the pour-thru method.

${ }^{\mathrm{z}}$ Means in a column followed by different letters are significantly different at the $P \leq 0.05$ level, Tukey Test.

${ }^{\mathrm{y}}$ Treatments in a row followed by different letters are significantly different at the $P \leq 0.05$ level, Holm-Sidak method.

${ }^{\mathrm{x}}$ Data for EC in 2012 passed Equal Variance Test and Normality Test (Shapiro Wilk). 
Table 2.13. Leachate EC (mS/cm) of media in biodegradable pots used to grow Lavendula angustifolia 'Elegans Ice' in $2012^{\mathrm{x}}$.

\begin{tabular}{lccccccc}
\hline Container Type & $\begin{array}{c}\text { Week } 0 \\
\mathrm{~b}^{\mathrm{yz}}\end{array}$ & $\begin{array}{c}\text { Week 2 } \\
\mathrm{c}^{\mathrm{z}}\end{array}$ & $\begin{array}{c}\text { Week } \\
\mathrm{b}^{\mathrm{z}}\end{array}$ & $\begin{array}{c}\text { Week } 6 \\
\mathrm{a}^{\mathrm{z}}\end{array}$ & $\begin{array}{c}\text { Week } 8 \\
\mathrm{c}^{\mathrm{z}}\end{array}$ & $\begin{array}{c}\text { Week 10 } \\
\mathrm{c}^{\mathrm{z}}\end{array}$ & $\begin{array}{c}\text { Week 12 } \\
\mathrm{c}^{\mathrm{z}}\end{array}$ \\
\hline Coir & $2504.7 \mathrm{a}$ & $1377.1 \mathrm{ab}$ & $2070.8 \mathrm{a}$ & $2832.8 \mathrm{a}$ & $1480.0 \mathrm{a}$ & $1825.2 \mathrm{ab}$ & $1330.8 \mathrm{a}$ \\
Manure & $1850.7 \mathrm{ab}$ & $996.6 \mathrm{~b}$ & $1670.2 \mathrm{a}$ & $2390.1 \mathrm{a}$ & $1372.3 \mathrm{a}$ & $2128.9 \mathrm{a}$ & $1598.4 \mathrm{a}$ \\
Wood Fiber & $1354.1 \mathrm{~b}$ & $1205.2 \mathrm{ab}$ & $2269.7 \mathrm{a}$ & $2511.3 \mathrm{a}$ & $1116.2 \mathrm{a}$ & $1182.9 \mathrm{ab}$ & $1193.3 \mathrm{a}$ \\
Peat & $1228.9 \mathrm{~b}$ & $947.9 \mathrm{~b}$ & $2098.2 \mathrm{a}$ & $2358.6 \mathrm{a}$ & $1567.1 \mathrm{a}$ & $1200.8 \mathrm{ab}$ & $1240.2 \mathrm{a}$ \\
Slot. Rice Hull & $2356.9 \mathrm{a}$ & $1682.3 \mathrm{ab}$ & $1530.0 \mathrm{a}$ & $2491.8 \mathrm{a}$ & $1155.5 \mathrm{a}$ & $1933.4 \mathrm{ab}$ & $1216.8 \mathrm{a}$ \\
PLA Bioplastic & $1684.9 \mathrm{ab}$ & $1593.9 \mathrm{ab}$ & $1651.4 \mathrm{a}$ & $2717.4 \mathrm{a}$ & $1470.2 \mathrm{a}$ & $1041.5 \mathrm{~b}$ & $1286.4 \mathrm{a}$ \\
PHA Bioplastic & $1772.3 \mathrm{ab}$ & $1270.8 \mathrm{ab}$ & $1373.3 \mathrm{a}$ & $2423.8 \mathrm{a}$ & $1018.7 \mathrm{a}$ & $1274.4 \mathrm{ab}$ & $1206.5 \mathrm{a}$ \\
Solid Rice Hull & $1812.2 \mathrm{ab}$ & $1758.3 \mathrm{ab}$ & $1726.9 \mathrm{a}$ & $2633.6 \mathrm{a}$ & $1944.4 \mathrm{a}$ & $1197.8 \mathrm{ab}$ & $1297.3 \mathrm{a}$ \\
Straw & $1844.2 \mathrm{ab}$ & $1374.7 \mathrm{ab}$ & $1877.9 \mathrm{a}$ & $2727.4 \mathrm{a}$ & $1443.9 \mathrm{a}$ & $1844.1 \mathrm{ab}$ & $1185.5 \mathrm{a}$ \\
\hline Plastic & $1906.7 \mathrm{ab}$ & $2027.7 \mathrm{a}$ & $1633.9 \mathrm{a}$ & $3016.3 \mathrm{a}$ & $1345.0 \mathrm{a}$ & $1245.9 \mathrm{ab}$ & $1228.6 \mathrm{a}$
\end{tabular}

\section{$\underline{\text { ANOVA }}$}

Pot $\quad 0.002$

Week <0.001

Pot vs. Week $\quad 0.001$

Values are means of three experimental units replicated over time. Statistical analysis using ANOVA with Tukey's Test or Holm-Sidak used to indicate if treatments were different from other treatments. Biweekly leachate EC measurements were taken using the pour-thru method.

${ }^{\mathrm{z}}$ Means in a column followed by different letters are significantly different at the $P \leq 0.05$ level, Tukey Test.

${ }^{\mathrm{y}}$ Treatments in a row followed by different letters are significantly different at the $P \leq 0.05$ level, Holm-Sidak method.

${ }^{x}$ Data for EC in 2012 passed Equal Variance Test and Normality Test (Shapiro Wilk). 


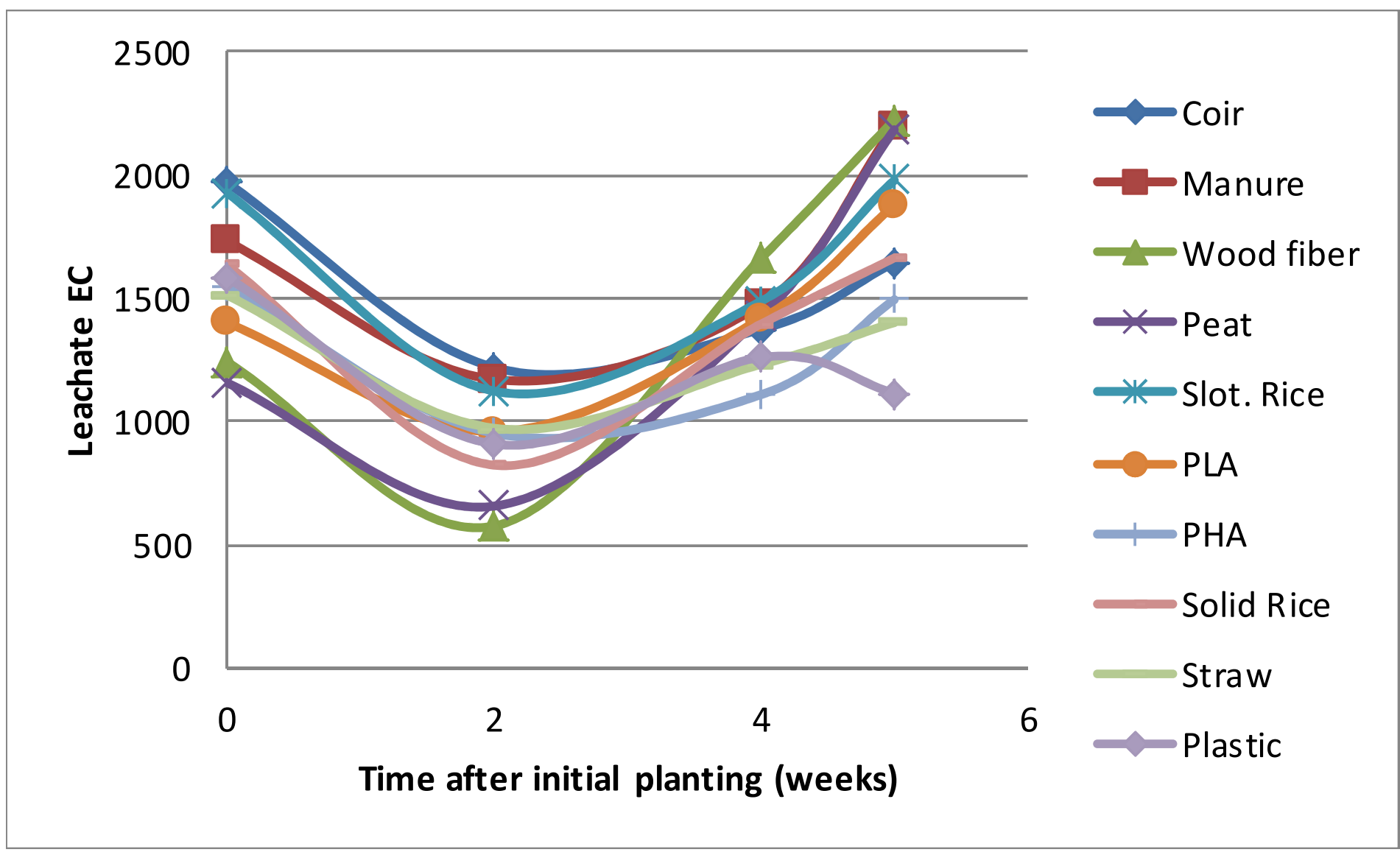

Figure 2.8. Leachate EC of media in biodegradable pots used to grow Impatiens spp. 'Sunpatiens Compact' in 2011. Values are means of three experimental units replicated over time. Statistical analysis using ANOVA.

Biweekly leachate EC measurements were taken using the pour-thru method. 


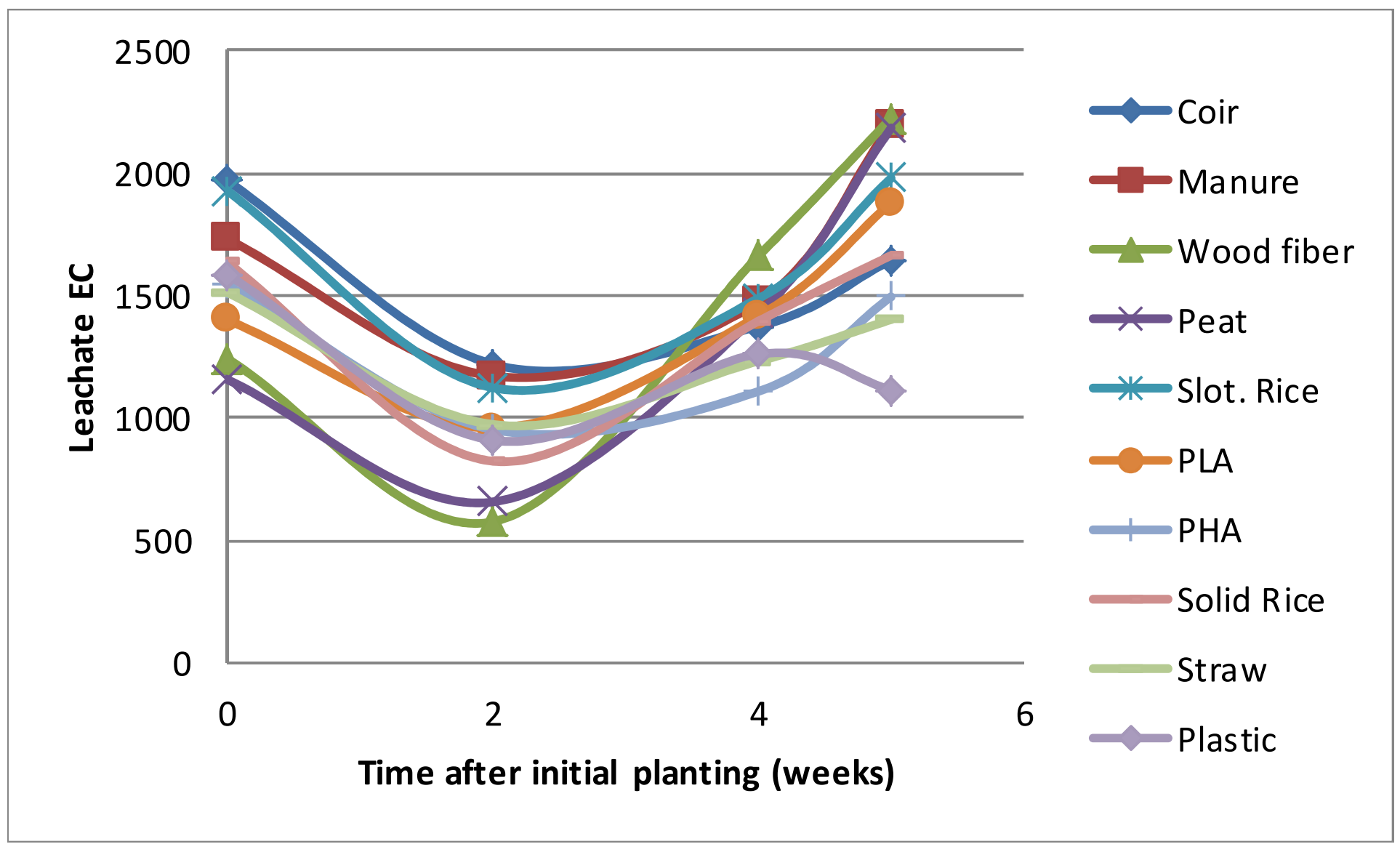

Figure 2.9. Leachate EC of media in biodegradable pots used to grow Lavendula angustifolia 'Elegans Ice' in 2011. Values are means of three experimental units replicated over time. Statistical analysis ANOVA.

Biweekly leachate EC measurements were taken using the pour-thru method. 


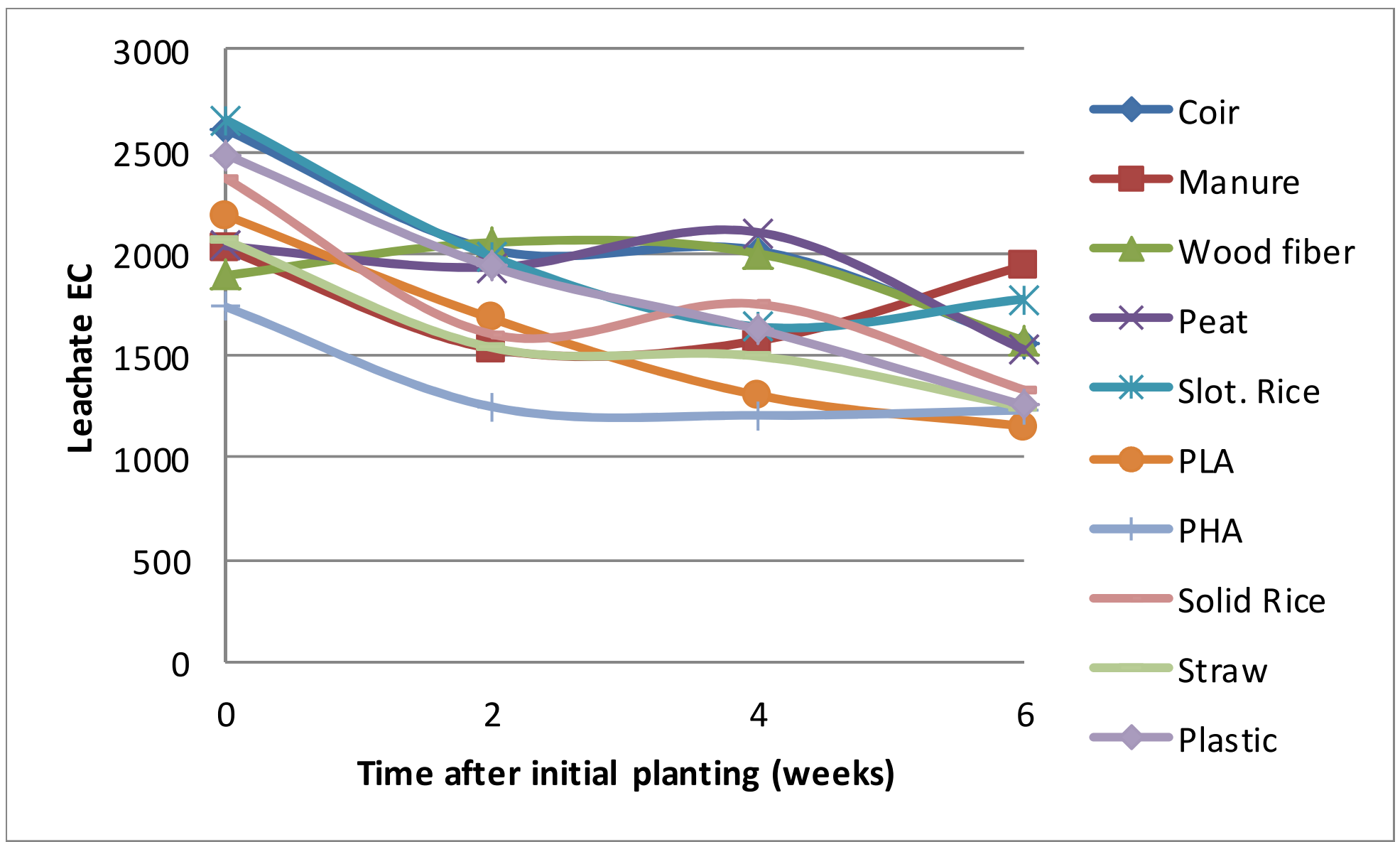

Figure 2.10. Leachate EC of media in biodegradable pots used to grow Impatiens spp. 'Sunpatiens Compact' in 2012. Values are means of three experimental units replicated over time.

Statistical analysis using ANOVA.

Biweekly leachate EC measurements were taken using the pour-thru method. 


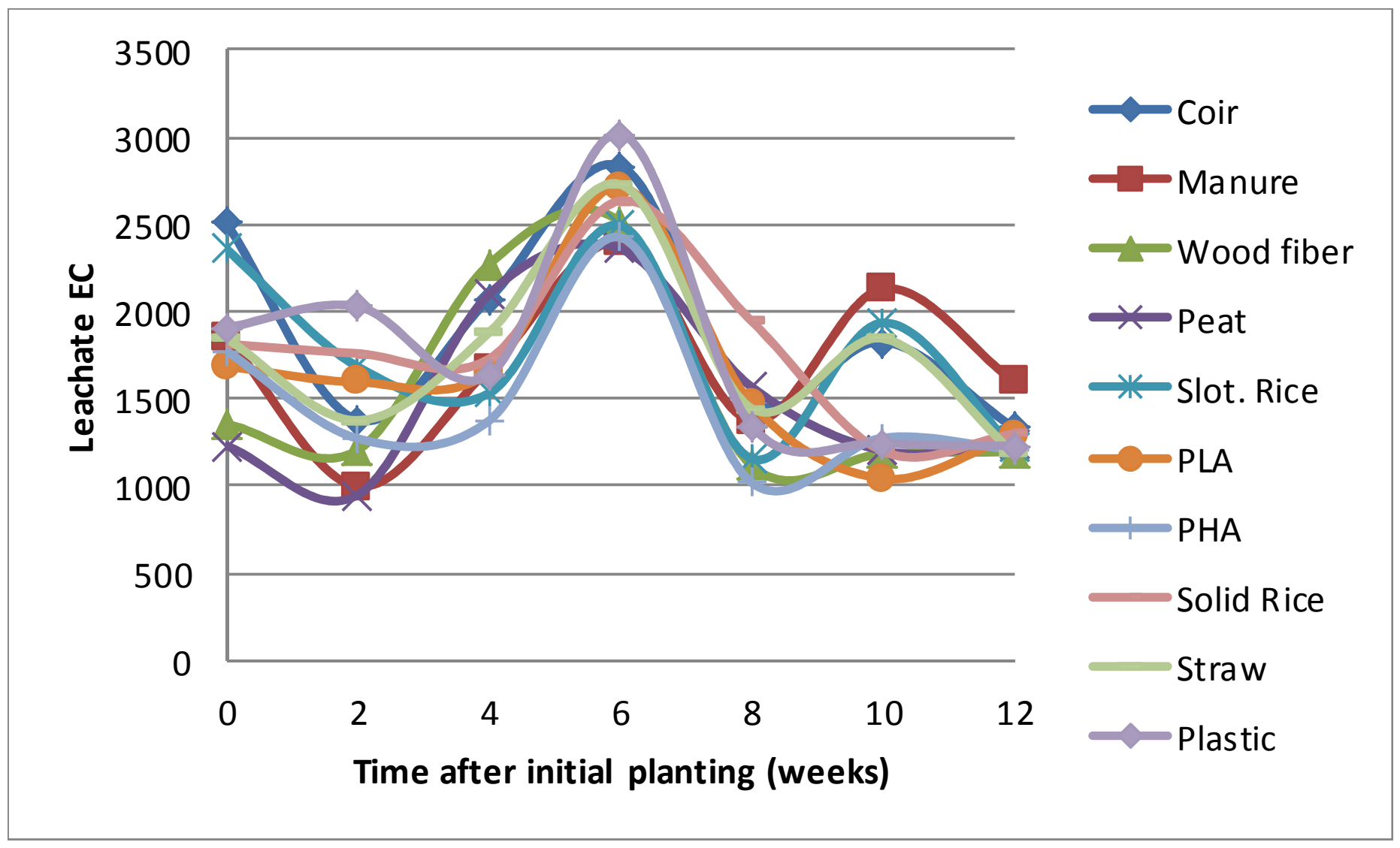

Figure 2.11. Leachate EC of media in biodegradable pots used to grow Lavendula angustifolia 'Elegans Ice' in 2012. Values are means of three experimental units replicated over time. Statistical analysis ANOVA. Biweekly leachate EC measurements were taken using the pour-thru method. 
Table 2.14. Pot characteristics of biodegradable containers used to grow Impatiens spp.

'Sunpatiens Compact' in 2011.

\begin{tabular}{|c|c|c|c|c|}
\hline Container Type & $\begin{array}{c}\text { Watering } \\
\text { Frequencv }^{\mathrm{y}}\end{array}$ & $\begin{array}{c}\text { Algal/Fungal } \\
(\mathrm{kg})^{\mathrm{xz}}\end{array}$ & Punch $(\mathrm{kg}) \mathrm{x}^{\mathrm{z}}$ & Tensile $(\mathrm{kg})^{\mathrm{xz}}$ \\
\hline Coir & $14.3 \mathrm{a}$ & $0.0 \mathrm{a}$ & $22.3 \mathrm{a}$ & $>10 a$ \\
\hline Manure & $13.3 \mathrm{a}$ & $0.0 \mathrm{a}$ & $0.2 \mathrm{c}$ & $0.0 \mathrm{c}$ \\
\hline Wood Fiber & $15.3 \mathrm{a}$ & $38.4 \mathrm{a}$ & $0.3 \mathrm{c}$ & $0.0 \mathrm{c}$ \\
\hline Peat & $16.0 \mathrm{a}$ & $34.0 \mathrm{a}$ & $0.2 \mathrm{c}$ & $0.0 \mathrm{c}$ \\
\hline Slot. Rice Hull & $15.7 \mathrm{a}$ & $0.0 \mathrm{a}$ & $2.3 \mathrm{c}$ & $>10 a$ \\
\hline PLA Bioplastic & $12.7 \mathrm{a}$ & $0.0 \mathrm{a}$ & $4.5 \mathrm{~b}$ & $>10 a$ \\
\hline PHA Bioplastic & $12.3 \mathrm{a}$ & $0.0 \mathrm{a}$ & $2.4 \mathrm{c}$ & . \\
\hline Solid Rice Hull & $15.0 \mathrm{a}$ & $0.0 \mathrm{a}$ & $6.8 \mathrm{~b}$ & $>10 a$ \\
\hline Straw & $13.0 \mathrm{a}$ & $0.0 \mathrm{a}$ & $2.8 \mathrm{c}$ & $5.8 \mathrm{~b}$ \\
\hline Plastic & $14.0 \mathrm{a}$ & $0.0 \mathrm{a}$ & 19.9 a & $>10 a$ \\
\hline $\mathrm{P}$ value & 0.258 & 0.006 & $<0.001$ & $<0.001$ \\
\hline
\end{tabular}

Experimental units were replicated three times. Statistical analysis was made using ANOVA.

Holm-Sidak method was used to indicate differences between treatments (as indicated by lower case letters).

Missing data represented by "."

Watering frequency was recorded throughout the experiment.

Pot strength and algal/fungal growth was assessed at the end of the experiment.

${ }^{\mathrm{z}}$ Means in a column followed by different letters are significantly different at the $\mathrm{P} \leq 0.05$ level, Holm-Sidak method.

${ }^{\mathrm{y}}$ Data passed Normality Test (Shapiro Wilk) and Equal Variance Test.

${ }^{\mathrm{x}}$ Data passed Equal Variance Test, but failed Normality Test (Shapiro Wilk). 
Table 2.15. Pot characteristics of biodegradable containers used to grow Lavendula angustifolia

'Elegans Ice' in 2011.

\begin{tabular}{|c|c|c|c|c|}
\hline Container & $\begin{array}{c}\text { Watering } \\
\text { Frequency }\end{array}$ & Algal/Fungal $(\mathrm{kg})^{\mathrm{xz}}$ & Punch $(\mathrm{kg}) \mathrm{w}^{\mathrm{z}}$ & Tensile $(\mathrm{kg})^{\mathrm{xz}}$ \\
\hline$\overline{\text { Coir }}$ & $17.7 \mathrm{ab}$ & $0.0 \mathrm{c}$ & $7.7 \mathrm{~b}$ & $10.0 \mathrm{a}$ \\
\hline Wood Fib & $21.3 \mathrm{ab}$ & $97.2 \mathrm{~b}$ & $0.2 \mathrm{e}$ & $0 \mathrm{c}$ \\
\hline Peat & $25.0 \mathrm{a}$ & 142.2 & $0.2 \mathrm{e}$ & $0 \mathrm{c}$ \\
\hline Slot. Rice & $18.0 \mathrm{ab}$ & $0.0 \mathrm{c}$ & $1.4 \mathrm{de}$ & $10.0 \mathrm{a}$ \\
\hline PLA Biop & $13.7 \mathrm{~b}$ & $0.0 \mathrm{c}$ & $3.5 \mathrm{c}$ & $10.0 \mathrm{a}$ \\
\hline PHA Biop & $14.0 \mathrm{~b}$ & $0.0 \mathrm{c}$ & $2.5 \mathrm{~cd}$ & . \\
\hline Solid Rice & $17.7 \mathrm{ab}$ & $0.0 \mathrm{c}$ & $6.4 \mathrm{~b}$ & $10.0 \mathrm{a}$ \\
\hline Straw & $16.0 \mathrm{ab}$ & $0.0 \mathrm{c}$ & $1.3 \mathrm{de}$ & $4.1 \mathrm{~b}$ \\
\hline Plastic & $15.7 \mathrm{ab}$ & $0.0 \mathrm{c}$ & $19.6 \mathrm{a}$ & $10 \mathrm{a}$ \\
\hline
\end{tabular}

Experimental units were replicated three times. Statistical analysis was made using ANOVA.

Holm-Sidak method was used to indicate differences between treatments (as indicated by lower case letters).

Missing data represented by "."

Watering frequency was recorded throughout the experiment.

Pot strength and algal/fungal growth was assessed at the end of the experiment.

${ }^{\mathrm{z}}$ Means in a column followed by different letters are significantly different at the $\mathrm{P} \leq 0.05$ level, Holm-Sidak method.

${ }^{\mathrm{y}}$ Data passed Normality Test (Shapiro Wilk) and Equal Variance Test.

${ }^{\mathrm{x}}$ Data passed Equal Variance Test, but failed Normality Test (Shapiro Wilk).

${ }^{\mathrm{w}}$ Data failed Normality Test (Shapiro Wilk) and Equal Variance Test. 
Table 2.16. Pot characteristics of biodegradable containers used to grow Impatiens spp.

'Sunpatiens Compact' in 2012.

\begin{tabular}{|c|c|c|c|c|}
\hline Container Type & $\begin{array}{c}\text { Watering } \\
\text { Erequency }\end{array}$ & Algal/Fungal $(\mathrm{kg})^{\mathrm{xz}}$ & Punch $(\mathrm{kg})^{\mathrm{xz}}$ & Tensile $(\mathrm{kg})^{\mathrm{xz}}$ \\
\hline Coir & $20.7 \mathrm{abcd}^{2}$ & $0.0 \mathrm{c}$ & $19.1 \mathrm{a}$ & $>10 a$ \\
\hline Manure & $23.3 \mathrm{ab}$ & $24.1 \mathrm{~b}$ & $0.3 \mathrm{c}$ & $0.0 \mathrm{c}$ \\
\hline Wood Fiber & $25.0 \mathrm{a}$ & $40.2 \mathrm{a}$ & $0.3 \mathrm{c}$ & $0.0 \mathrm{c}$ \\
\hline Peat & $25.0 \mathrm{a}$ & $37.6 \mathrm{a}$ & $0.7 \mathrm{c}$ & $1.9 \mathrm{~b}$ \\
\hline Slot. Rice Hull & $16.7 \mathrm{~cd}$ & $0.0 \mathrm{c}$ & $2.1 \mathrm{c}$ & $>10 a$ \\
\hline PLA Bioplastic & $18.7 \mathrm{bcd}$ & $0.0 \mathrm{c}$ & $3.9 \mathrm{bc}$ & $>10 a$ \\
\hline PHA Bioplastic & $16.3 \mathrm{~d}$ & $0.0 \mathrm{c}$ & $1.0 \mathrm{c}$ & . \\
\hline Solid Rice Hull & $20.3 \mathrm{abcd}$ & $0.0 \mathrm{c}$ & $6.7 \mathrm{bc}$ & $>10 \mathrm{a}$ \\
\hline Straw & $16.7 \mathrm{~cd}$ & $0.0 \mathrm{c}$ & $3.0 \mathrm{bc}$ & $2.2 \mathrm{~b}$ \\
\hline Plastic & $21.3 \mathrm{abc}$ & $0.0 \mathrm{c}$ & $14.4 \mathrm{ab}$ & $>10 a$ \\
\hline$P$ value & $<0.001$ & $<0.001$ & $<0.001$ & $<0.001$ \\
\hline
\end{tabular}

Experimental units were replicated three times. Statistical analysis was made using ANOVA.

Holm-Sidak method was used to indicate differences between treatments (as indicated by lower case letters).

Missing data represented by "."

Watering frequency was recorded throughout the experiment.

Pot strength and algal/fungal growth was assessed at the end of the experiment.

${ }^{\mathrm{z}}$ Means in a column followed by different letters are significantly different at the $\mathrm{P} \leq 0.05$ level, Holm-Sidak method.

${ }^{\mathrm{y}}$ Data passed Normality Test (Shapiro Wilk) and Equal Variance Test.

${ }^{\mathrm{x}}$ Data passed Equal Variance Test, but failed Normality Test (Shapiro Wilk). 
Table 2.17. Pot characteristics of biodegradable containers used to grow Lavendula angustifolia

'Elegans Ice' in 2012.

\begin{tabular}{|c|c|c|c|c|}
\hline Container & $\begin{array}{c}\text { Watering } \\
\text { Frequency }\end{array}$ & Algal/Fungal $(\mathrm{kg})^{\mathrm{xz}}$ & Punch $(\mathrm{kg})^{\mathrm{xz}}$ & Tensile $(\mathrm{kg})^{\mathrm{xz}}$ \\
\hline Coir & $36.3 \mathrm{a}$ & $0.0 \mathrm{~b}$ & $12.5 \mathrm{~b}$ & $10.0 \mathrm{a}$ \\
\hline Wood Fib & $34.3 \mathrm{ab}$ & 89.9 a & $0.3 \mathrm{e}$ & $0.0 \mathrm{c}$ \\
\hline Peat & $36.3 \mathrm{a}$ & $69.0 \mathrm{a}$ & 0.5 & $2.6 \mathrm{~b}$ \\
\hline Slot. Rice & $31.7 \mathrm{ab}$ & $0.0 \mathrm{~b}$ & $1.7 \mathrm{de}$ & $10.0 \mathrm{a}$ \\
\hline PLA Biop & $29.0 \mathrm{ab}$ & $0.0 \mathrm{~b}$ & 1.5 & $10.0 \mathrm{a}$ \\
\hline PHA Biop & $27.3 \mathrm{~b}$ & $0.0 \mathrm{~b}$ & $0.6 \mathrm{de}$ & . \\
\hline Solid Rice & $29.7 \mathrm{ab}$ & $0.0 \mathrm{~b}$ & 7.2 & $10.0 \mathrm{a}$ \\
\hline Straw & $27.0 \mathrm{~b}$ & $0.0 \mathrm{~b}$ & $2.2 \mathrm{~d}$ & $3.6 \mathrm{~b}$ \\
\hline Plastic & $30.0 \mathrm{ab}$ & $0.0 \mathrm{~b}$ & 20.0 & $10.0 \mathrm{a}$ \\
\hline
\end{tabular}

Experimental units were replicated three times. Statistical analysis was made using ANOVA.

Holm-Sidak method was used to indicate differences between treatments (as indicated by lower case letters).

Missing data represented by "."

Watering frequency was recorded throughout the experiment.

Pot strength and algal/fungal growth was assessed at the end of the experiment.

${ }^{\mathrm{z}}$ Means in a column followed by different letters are significantly different at the $\mathrm{P} \leq 0.05$ level, Holm-Sidak method.

${ }^{\mathrm{y}}$ Data passed Normality Test (Shapiro Wilk) and Equal Variance Test.

${ }^{\mathrm{x}}$ Data passed Equal Variance Test, but failed Normality Test (Shapiro Wilk). 


\section{Chapter 3: Evaluating the Performance of Biodegradable Pots in a Landscape Setting}

Note: This work is part of a multi-institutional research initiative with additional trials conducted at research facilities associated with the University of Illinois, Mississippi State University, and Texas A\&M University. For this thesis chapter, only work conducted at West Virginia University is reported. The final publication to be submitted for peer review will include results from all four locations.

\section{Summary}

Recent introductions of several new biodegradable containers to the market have resulted in research investigating biopots as potential alternatives to petroleum-based plastic containers. Most research has focused on the performance of biodegradable pots in greenhouse settings and their ability to withstand production environments. Little information is available pertaining to the performance and degradability of these pots in the landscape. This research evaluated seven plantable biopots and their effect on the growth and development of annuals during a growing season (15 weeks) in the landscape. Above ground growth for the three crops, Lantana camara 'Luscious Citrus', Cleome hassleriana 'Senorita Rosalita', and Impatiens sp. 'Sunpatiens Compact' was observed throughout the season, as well as pot degradation at the end of the experiment. Results showed few differences in overall plant growth among the biopots tested, and no significant differences were apparent in the visual quality ratings of plants at the end of the growing season. Significant differences, however, were observed in pot degradation, as a pattern of three tiers of pot performance emerged. Cowpot, a pot made from composted dairy manure occupied the top tier with the most significant pot degradation at the end of the season. Pots made of peat, straw, and PHA bioplastic were in the second tier. Pots made of coir, slotted rice hulls, and wood fibers showed the least amount of degradation and were placed in a third tier of biodegradability. 


\section{$\underline{\text { Background }}$}

Plastic containers for plant production have become a standard in the horticulture industry because of their durability and flexibility to be made into virtually any size, shape, or color (Evans et al., 2010). Plastic containers, however, have two significant limitations. First, the container walls are impermeable, so when the roots contact the surface, they tend to circle the container (Evans and Karcher, 2004). Root circling can be detrimental to a plant for numerous reasons, including girdling of the stem, failing to adequately anchor plants once planted, restricting the uptake of water, and decreasing nutrient absorption (Appleton, 1989). The second limitation to plastic is the issue of proper disposal (Evans and Karcher, 2004). The horticulture industry contributes a large part to the overall waste stream in the U.S. In 1993, Garthe and Kowal (1993) found that of the 542 million pounds of plastic used in agriculture annually, 320 million pounds, or $59 \%$, was attributed to plant containers. While agricultural plastic only contributes about $1 \%$ to the total plastic waste stream in the US, the amount of waste is still significant and could be improved upon (Garthe and Kowal, 1993; EPA, 2010).

Although solutions to reduce plastic waste have been proposed, many are not feasible for the horticulture industry. Some plastic containers can be reused within the greenhouse and nursery setting, but the cost of cleaning and sterilizing often hinders this process. Another solution to reducing plastic waste is recycling, but recycling of horticulture products is complicated by contamination with soil and plant residue, grease, moisture, pesticides, and UV light degradation of the plastics (Garthe and Kowal, 1993).

Since recycling options for containers are limited and reuse is not always feasible, the industry must move in a different direction to reduce plastic waste (Evans et al., 2010). One 
possible solution is the use of biodegradable containers, or biopots. Biopots are containers not produced from petroleum that degrade rapidly and reduce the need for disposal (Evans et al., 2010). "Rapidly" could be defined as one plant season, or several years, depending on the type of pots being used. Plantable biopots are designed to be left intact on the root ball upon planting, and allow the roots to grow through the container walls, thus decreasing the potential for root circling and transplanting stress that could be associated with non-plantable biopots. The pots also could have a labor saving cost component, as they require less time to plant, and reduce plastic waste that needs clean up and disposal after planting.

Most biopot research has studied the water use of specific biopots. Evans and Karcher (2004) found that plants grown in a greenhouse in peat and feather fiber biopots required more frequent irrigation and more water overall when compared to plants grown in plastic pots. This is believed to be attributed to a faster rate of evaporation through container walls due to the porous nature of the pot (Evans and Hensley, 2004). In the landscape, pots made of porous material could also experience more or less water loss from the root zone to the surrounding soil when compared to standard planting methods, resulting in possible increased or decreased desiccation of the plant. However, very little, if any, in depth research has focused on the performance of biopots in the landscape (Evans et al., 2010).

One of the greatest issues facing biopots is the uncertainty as to whether these pots could endure the production process in the greenhouse and hold up during the marketing to consumer, yet still degrade in the landscape. The wet and dry vertical strengths has been tested and some pots, such as rice hull and manure, have high dry vertical strengths, sometimes even higher than plastic. Unsurprisingly, the wet strength of biopots was found to be lower than the dry strength 
(Evans et al., 2010). In fact, after four weeks in a greenhouse setting, wood fiber, peat, and manure pots had such low wet vertical strengths, that manual handling was found to be difficult (Evans et al., 2010). This same study found that after 8 weeks in the landscape, manure pots had the highest level of decomposition, followed by peat, rice straw, and wood fiber containers, though no measurements pertaining to plant growth were taken (Evans et al., 2010).

The objectives of this study were to evaluate the effects of biodegradable pots on plants grown in the landscape, and to evaluate the container degradation of seven plantable biocontainers during two summer seasons using a low, medium, and high water requiring crop.

\section{Materials and Methods}

\section{Location and Environment}

The landscape performance experiment was conducted in a research field plot at the West Virginia University Agronomy Farm in Morgantown, WV (US Hardiness Zone 6a), measuring approximately 9 by 21 meters. Prior to planting, the plot was tilled and leveled. Black plastic/landscape fabric was laid down to prevent weed growth, and a six-foot-tall wildlife netting fence was placed around the perimeter of the plot. The first trial of the experiment began on June 28, 2011 and ended October 9, 2011. The second trial began June 25, 2012 and ended October 9, 2012.

Mean temperatures for 2011 and 2012 were comparable (Figure 3.1), but precipitation amounts varied greatly between years (Figure 3.2). Initial ANOVA analysis of the data showed differences in some measurements between years, but no pot-by-year interaction. Given this 
difference between seasons and the differences in experimental design (fewer replications), the results were analyzed and discussed by year.

\section{Pots}

Seven types of plantable biopots were evaluated for their performance in a landscape setting and compared to a control plastic pot (Table 3.1). The plastic control pots were removed before planting while other plants were planted with the biopot intact. Pot materials included coir (Coir), composted manure (Cowpot), spruce wood fiber (Fertil), peat (Jiffy), slotted rice hulls (Net), rice straw (Straw), and a bioplastic polyhydroxyalkanoate (PHA) sleeve (Soilwrap) (Table 3.1). Pots will hereafter be referred to by their material composition.

\section{Plant Material}

Plant material was selected based on the overall water requirement and adaptability across a wide range of climates, given that several universities were involved in the research. Lantana camara 'Luscious Citrus', Cleome hassleriana 'Senorita Rosalita', and Impatiens sp. 'Sunpatiens Compact' were selected to represent low, medium, and high water requiring plants respectively. Plants were purchased as 84-cell plugs and transplanted into the biopots in May for both 2011 and 2012 trials. Plants were grown to marketable size in the greenhouse (approximately six weeks) in 4-inch pots using a commercial growing mix (Fafard 2, FPM Peat Moss Company, Ltd., Agawam, MA). The plants were irrigated as needed and fertilized at every watering with 150 ppm N from a 20-10-20 fertilizer (Scotts, Marysville, OH). Temperature set points were $20{ }^{\circ} \mathrm{C} / 20{ }^{\circ} \mathrm{C}(\mathrm{D} / \mathrm{N})$. The plants were pinched before being planted in the landscape to encourage branching and uniformity. 


\section{Experimental Design}

Plants were grouped by species and each species and its treatments (biopot type) were arranged in a complete randomized design, with an individual potted plant serving as the experimental unit. In 2011, the experiment was arranged in 10 rows of 8 plants each, with a total of ten replications representing each pot type (10 plants x 8 pots). In 2012, the experiment was arranged in 8 rows of 8 plants each, with a total of 8 replications representing each pot type (8 plants $x 8$ pots). An "X" was cut in the plastic/landscape fabric, and holes were dug to an adequate size (slightly bigger than the pot), with a spacing of two feet between rows and individual plants within the row. Plantable pots were placed in the hole, and covered lightly with soil. Plastic pots were removed from plants before planting.

\section{Irrigation and Fertilization in the Field}

A drip irrigation system was installed so that each plant had an emitter directly above its root zone. Plants were checked once a week and irrigation was applied for approximately 1 to 2 hours to individual experiments during the establishment phase (2-3 weeks) as needed. Plants were fertilized with one tablespoon of 13-13-13 T100 slow release fertilizer (Nutricote, Plant Products Co., Ontario, Canada) once after initial plant establishment.

\section{Pot and Plant Performance Measurements}

Measurements of height and width (in two directions E-W and N-S) were taken at the start of the experiment and again after approximately 2 months of growth (August $16^{\text {th }}, 2011$ and August $25^{\text {th }}, 2012$ ), followed by a final measurement on October 9 in 2011 and 2012. At the conclusion of the experiment, plants were assigned a numerical value indicating overall quality 
rating. A score of " 1 " represented a plant that was completely dead, with no green growth apparent, while " 2 " represented plants that still had some green growth but were of very poor quality. Scores of "3" were given to plants of fair quality, such as plants stunted in growth, or with noticeable insect damage. Good quality plants with open flowers and limited insect damage and blemishes were scored a "4", and plants that were considered of excellent quality, with little to no insect damage, and large size with many open flowers, were scored a "5". Plants were then harvested by severing the stems at the soil surface and the biomass was immediately analyzed for fresh weight. The plants were placed in paper bags in a drying room at $46 \mathrm{C}^{\circ}$ and analyzed for dry weight after two weeks.

After harvesting, pots were excavated and allowed to dry for several days. The rootball was removed very carefully by using small carving knives to sever the roots from the pot, following by light tugging and twisting on the plant stem until the rootball was freed. The pots were individually photographed, then placed into bags and dried in a drying room at $46 \mathrm{C}^{\circ}$ for 2 weeks. Any remaining soil was lightly scraped off, and a final dry weight was taken. Postharvest dry weights were compared to the initial average weight of a new dried pot not subjected to field exposure to determine percent degradation.

\section{Statistical analysis}

Prior to ANOVA, the data were tested for homogeneity of variances (Bartlett's Test), and for normality (Shapiro-Wilk test), with Sigma Plot (Systat Software, Inc, San Jose, CA). Following a Two-Way Analysis of Variance, end of season pot and plant measurements were analyzed per year using a series of One-Way Analysis of Variance (ANOVAs). If pot type 
effects (treatments) were found, pairwise multiple comparisons were carried out using the HolmSidak method for separation of means.

\section{$\underline{\text { Results and Discussion }}$}

Mean monthly temperature and precipitation values for both experimental seasons are shown in Figures 3.1 and 3.2. Mean temperatures for 2011 and 2012 were comparable, but precipitation amounts varied greatly between years (Figure 3.1). Initial ANOVA analysis of the data showed differences in some measurements between years, but no pot-by-year interaction. Given this difference between seasons and the differences in experimental design (fewer replications), the results were analyzed and discussed by year.

\section{Plant Performance}

In the 2011 season, no significant differences were observed in data relating to plant growth and development. Across all pot types, lantana, cleome, and sunpatiens showed similar final width and height, fresh and dry weight, as well as visual ratings (Tables 3.2, 3.3, 3.4).

The 2012 season showed similar results to the 2011 experiment. Again, no differences were observed in the final width, dry weight, as well as visual ratings in any of the species tested. However, small differences were observed in 2012 in lantana plant final height, cleome final fresh weight, and sunpatiens fresh and dry weight and final width.

In 2012, only lantana grown in the plastic pot treatment was significantly taller $(P<0.001)$ than the other treatments, a fact that could be attributed to unimpeded growth after the pot was removed at planting. However, other plant-related measurements that could be considered better indicators of plant performance (final quality rating, fresh and dry weight) did 
not corroborate this observation. This leads to the conclusion that the impact of removing the container, in the case of the plastic control, is minimal when compared to planting biodegradable containers (Table 3.5).

In 2012, cleome also showed few differences among pot types. A significant treatment effect, $(P=0.042)$ was observed in fresh weight, but upon further analysis, differences among treatments could not be resolved with a separation of means test. Significant differences $(P=0.025)$ were observed in the final width of cleome plants in 2012 , specifically between the slotted rice hull and coir pot plants (Table 3.6). Again, the lack of corroboration with other measurements of plant growth (fresh and dry weight, plant rating) led to the conclusion that plantable pots perform similar to control plants with the plastic pot removed.

The 2012 sunpatiens trial showed significant differences among pot types in fresh weight $(P<0.001)$, dry weight $(P<0.001)$, and final width $(P=0.002)$. Upon further analysis, the pairwise multiple comparisons showed that peat consistently ranked lower than all other biopots in these three plant growth measurements (Table 3.7).

The 2011 season had considerably more precipitation compared to the 2012 season (Figure 3.2). At times during the 2011 season, excessive rainfall caused already saturated field plots to become flooded. This undoubtedly impacted the overall growth of plants, especially that of the sunpatiens (Table 3.4). In the 2011 sunpatiens results, typical plant ratings ranged from 13, whereas in 2012, plant ratings ranged from 4-5. Nonetheless, there were no differences between pot types in 2011 , leading us to conclude that the pot types responded similarly to the wet conditions. A few differences in plant growth were observed in 2012 , the drier year. A study that looked at the water use and irrigation interval of geraniums grown in 4-inch biopots in a 
greenhouse setting found that pots could be segregated into three groups of water use. Rice Hull and bioplastic containers had water usage similar to that of plastic. An intermediate group consisted of manure and paper containers. The group with the highest rate of water usage included the straw, coir, wood fiber, and peat pots (Taylor et al., 2010). The same study also found that wood fiber and peat pots had the highest rate of water loss through the container walls (Taylor et al., 2010). In a drier season, such as 2012, water could have been wicked from the porous containers into the surrounding soil. This could have impacted plant growth, and may explain why sunpatiens, a high water requiring crop, grown in peat pots in 2012 had significantly less growth than all other pot types. The higher water requirements of sunpatiens would also explain why in 2012, more differences in growth parameters were observed at the end of the season, than in lantana and cleome species that require less water.

The lack of consistent results pointing to a particular container as being superior in plant performance across species, measurements, or years, and the fact that no differences were observed in 2011, again leads us to conclude that most plantable pots perform similar to control plants with the plastic pot removed.

\section{Pot Performance}

Pot performance was measured by the percent degradation for each pot at the conclusion of the experiment. For all three species over both experimental seasons, there were significant differences $(P<0.001)$ in pot degradation.

In the 2011 lantana trial, pairwise comparisons revealed large differences between the percent degradation of several pots (Table 3.2). The manure pots ranked higher than all other pot 
types, with an average of 83.7 percent degradation over the season. The straw pot ranked second highest with a percent degradation of 44.1. Peat and slotted rice hull pots had average percent degradations of 20.1 and 23.5, respectively. However, these percentages of degradation were not significantly different from that of the PHA bioplastic sleeve at 8.2 percent. The PHA bioplastic was also not significantly different from the bottom ranking wood fiber and coir pots, showing 2.6 and 3.9 percent degradation, respectively.

The 2011 cleome trial showed similar results to that of the 2011 lantana trial. Again, manure pots had the highest percent degradation at 85.4 , not comparable to any other pot types, and straw pots again ranked second highest with 45.8 percent degradation. Peat and slotted rice hull pots ranked near the middle with 31.2 and 18.0 percent degradation, respectively. However, slotted rice hull was not significantly different from PHA bioplastic, wood fiber, or coir, the three lowest ranking with 7.1, 7.2, and 9.8 percent degradation, respectively (Table 3.3).

The 2011 sunpatiens trial showed results that corroborated the results of the two aforementioned cleome and lantana trials. Manure pots once more ranked highest with 69.7 percent degradation, followed by straw pots with 43.4 percent degradation. Coir and wood fiber pots again ranked the lowest among all pot types, with the addition of the peat pot, showing percent degradation of 12.2, 2.3, and 11.4, respectively (Table 3.4).

Slightly lower average pot degradations were observed for some pots during the 2011 sunpatiens trial when compared to the cleome and lantana trials. For example, manure pots, the highest ranked pot type in terms of percent degradation in all three trials, had an average percent degradation in the mid 80's for both the lantana and cleome trial, however only showed 69.7 percent degradation in the sunpatiens trial. As mentioned before, the 2011 season had noticeably 
more precipitation than the 2012 season, and the sunpatiens in particular were subjected to minor flooding. Although the plant ratings for the sunpatiens trial in 2011 showed no significant differences between pot types, the ratings were noticeably lower than the lantana and cleome trials during the same 2011 season. The low oxygen environment due to flooding may explain the decreased plant growth and quality, and may have also impacted the degradation of the pots in the 2011 sunpatiens trial.

The ranking of percent degradation of biopots was very similar in 2012 when compared to 2011. The manure again ranked highest in percent degradation among all pots in 2012 in the lantana trial, and showed 100 percent degradation. In a slightly different observation from the 2011 trials, the second highest rankings in pot degradation were found in PHA bioplastic, straw, and peat pots with pot degradation of $64.1,56.8$, and 44.8 percent, respectively. The wood fiber, slotted rice hull, and coir pots were ranked lowest, with average percent degradation of 11.9, 9.3, and 5.9, respectively (Table 3.5).

In the 2012 cleome trial, manure pots once more ranked the highest with 95.9 percent degradation, and straw pots again ranked the second highest with 52.8 percent degradation. Coir and wood fiber pots showed limited degradation with 13.6 and 3.2 percent degradation (Table 3.6).

Similar to the observations made in the 2012 cleome and lantana trial, manure ranked the highest with a percent degradation of 98.9 percent in the sunpatiens trial when compared to the other biopots. Straw pots, showing the second highest percent degradation at 48.7, was not significantly different from that of the wood fiber, peat, or PHA bioplastic pots with percent degradations of 30.4, 47.0, and 32.0, respectively. This is a slightly different result from the 2011 
sunpatiens trial when the second ranking straw pots were significantly different from all other pots, and the wood fiber and peat pots were among the lowest ranking. However, similar to the sunpatiens 2011 results, the coir and slotted rice hull pots showed 5.9 and 16.8 percent degradations, the lowest of all pot types (Table 3.7).

When comparing the percent pot degradation, a pattern emerges with three tiers of pot types, in which the top tier showed almost complete degradation over the growing season. In all six trials, manure was significantly different from its counterparts and consistently had the highest percentage of pot degradation. With the exclusion of the 2011 sunpatiens trial $(69.7 \%)$, which experienced poor root growth due to some flooding of the experimental field, manure pot degradation ranged from 83 to $100 \%$. In contrast, coir, slotted rice hull, and wood fiber pots consistently showed some of the lowest rankings in pot degradation in all trials, ranging from 2$30 \%$ in total pot degradation. Peat, PHA bioplastic, and straw pots comprised the middle tier, with percent degradations ranging from $7-64 \%$. Some overlap did occur between the middle and bottom tier. For example, the wood fiber pot showed 30.4 percent degradation in the 2012 sunpatiens trial, but for the remaining five trials, it was among the lowest ranked in pot degradation, with percent degradations ranging from 2.3 to 11.9 .

Much in the same way that a compost pile requires ideal environmental conditions in order to "work", several factors also will influence the rate of pot degradation. Some of these factors include moisture, temperature, $\mathrm{pH}$, pot material, nitrogen, and microbial activity (Nambuthiri et al., 2013). Many of these parameters were not studied as part of our experiments. However, the high cellulose content of the manure pots likely made it decompose more quickly than others, such as the coir pot, which has a high level of lignin. The availability of nitrogen 
present in the manure pots may have also increased microbial activity, further enhancing the decomposition of these pots (Evans et al., 2010).

Overall, very few differences were seen between pot types in plant growth parameters in the landscape study. Although some differences were observed in the 2012 experiments, it should be noted that these differences were not great enough to affect the overall plant quality rating at the end of the season for any of the species being studied. In addition, the occasional differences observed in plant growth do not match the pattern of percent degradation observed in our study.

Past research has focused on the water requirements of the specific biopots, and the potential for some pots to wick water more quickly. As previously mentioned, temperatures between the two seasons were comparable, but precipitation varied greatly. Specifically, the 2011 season was notably "wetter" than that of the 2012 season. Some of our species grew better in one season as compared to the other, but it is important to note that the increase or decrease in overall growth because of the environment was consistent among all pot types. These results suggest that when planted in the landscape, biopots are not subjected to the amount of water wicking that occurs in a greenhouse. A similar study conducted at Longwood Gardens in Kennett Square, PA, found that once planted in the field, plants grown in 4-inch plantable containers performed just as well as plants grown in traditional plastic containers. This research, as well as our own, suggests that when planted in the landscape, plantable biopots have the potential to grow a plant of comparable size and quality to that of a traditional plastic pot (Kuehny et al., 2011). 


\section{Conclusion}

The results show that pot degradation could impact pot selection if clean-up of annual beds is taken into account, especially in light of the fact that plant performance in the landscape was similar for all pots studied. In the landscape setting, it is important that biopots are able to degrade rapidly, so as not to impede plant growth, but also to prevent aesthetic and practical problems for future site uses. In this case, rapid degradation as seen in the manure pots would be beneficial. However, a fine balance must be established between a pot that is able to sufficiently degrade in the landscape, yet withstand handling and automation during production and transportation during marketing. While manure pots did show the greatest promise for rapid degradation in this study, my research and others have reported that when wet, manual handling of the manure pot was "found to be difficult" (Evans et al, 2010). Future research needs to be conducted to establish a strength and degradability threshold, in order to better enable growers to choose a pot both suitable for their own production needs, yet satisfy the needs of landscapers and retail consumers. 
Figure 3.1. Monthly mean temperature at the Morgantown, WV study site (USDA Hardiness Zone 6a) for the 2011 and 2012 growing seasons.

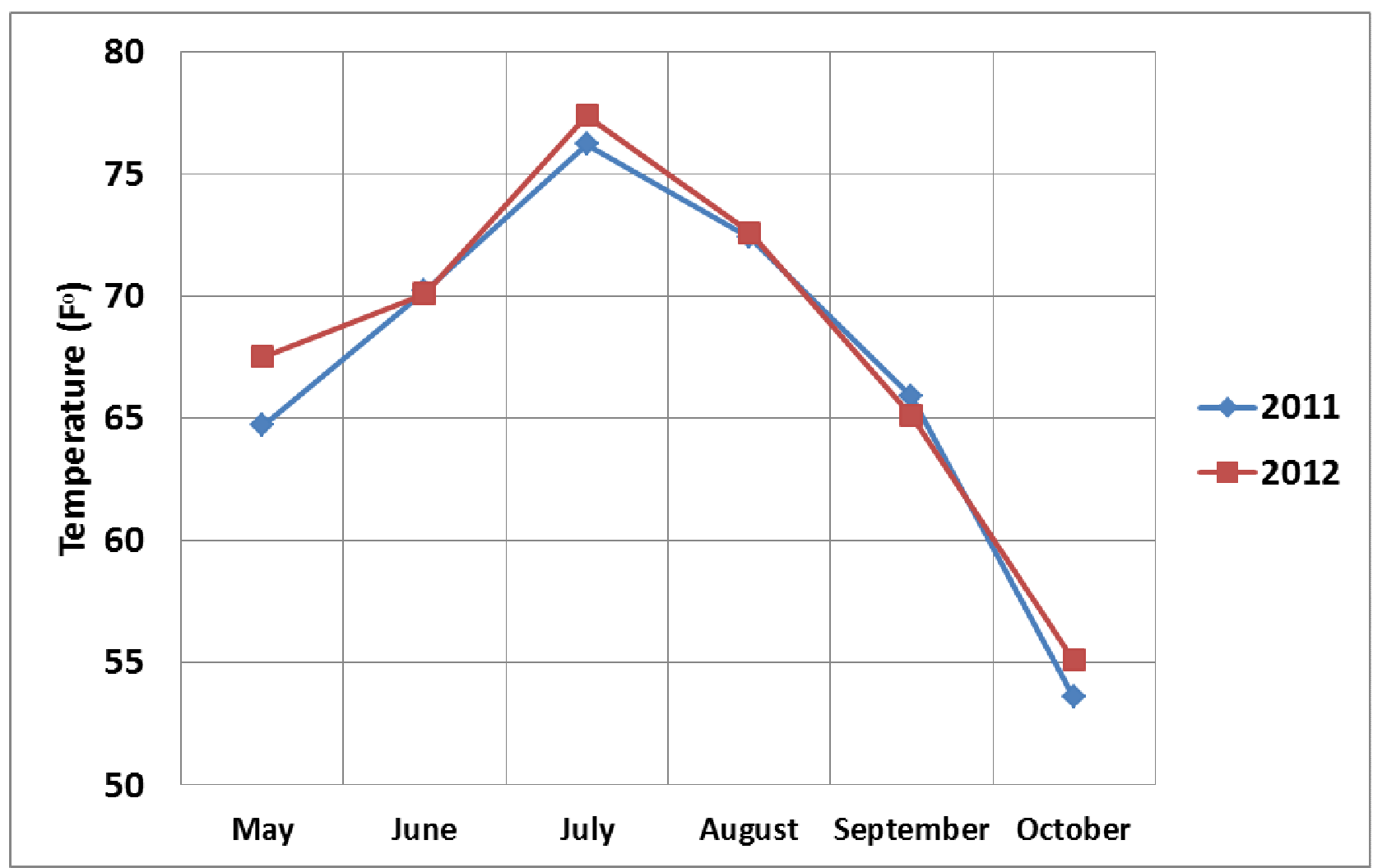


Figure 3.2. Monthly mean precipitation at the Morgantown, WV study site for the 2011 and 2012 growing seasons.

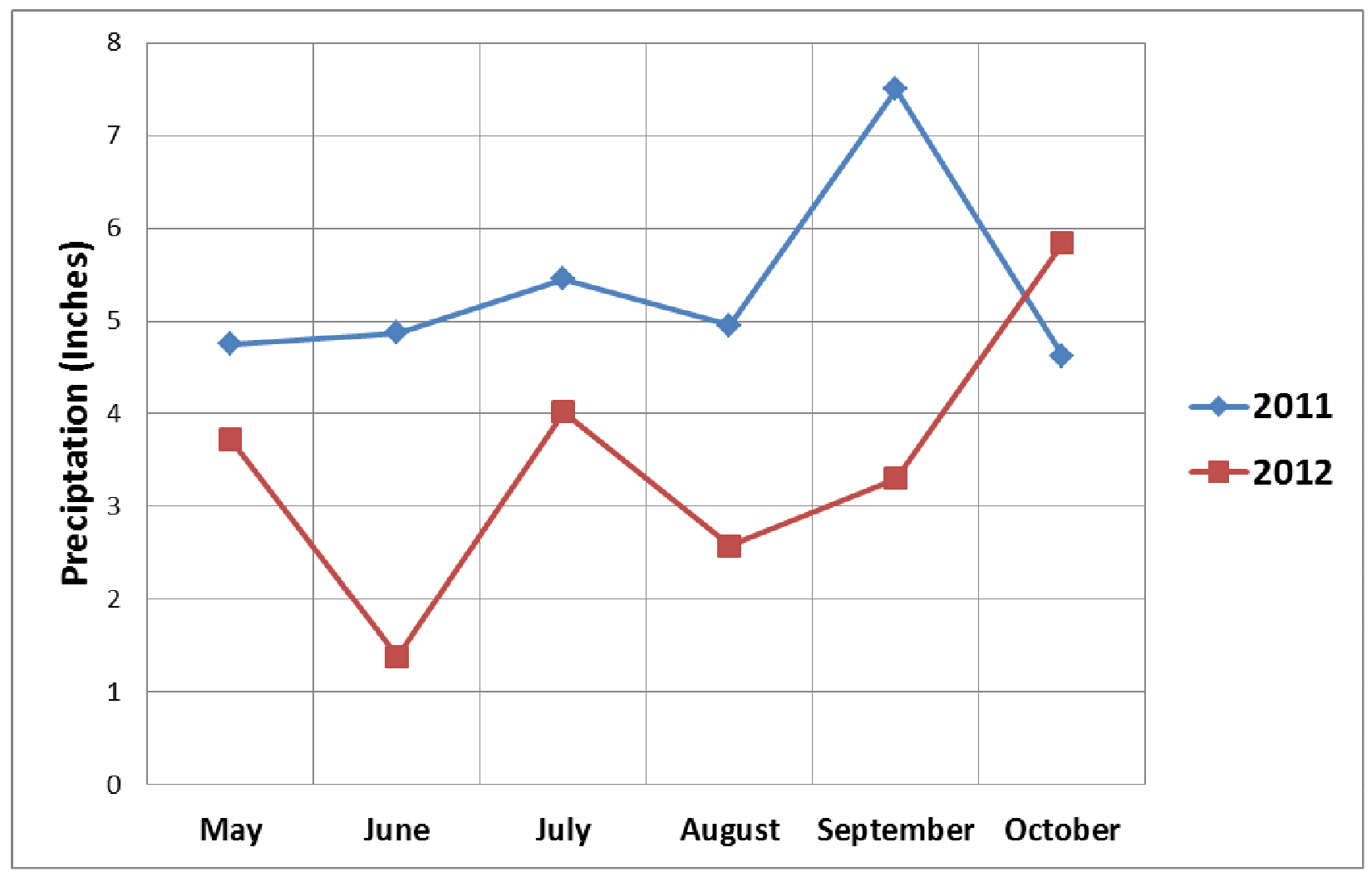


Table 3.1. The pot treatments used in this experiment, including product name, container component, and manufacturer information.

\begin{tabular}{|l|l|l|}
\hline Product Name & Container Component & Manufacturer \\
\hline $\begin{array}{l}\text { Dillen 04.00 Standard } \\
\text { Thinwall Green (plastic) }\end{array}$ & Injection molded Plastic & $\begin{array}{l}\text { Myers Industries Lawn \& } \\
\text { Garden Group, Middlefield, } \\
\text { OH }\end{array}$ \\
\hline $\begin{array}{l}\text { Coir 4.0" Std Fiber Gro Pot } \\
\text { (Coir) }\end{array}$ & Pressed coconut fiber & $\begin{array}{l}\text { Dillen Products, Middlefield, } \\
\text { OH }\end{array}$ \\
\hline \#4 Square CowPot (Manure) & Composted Manure Fiber & $\begin{array}{l}\text { CowPots Manufacturing and } \\
\text { Sales, East Canaan, CT }\end{array}$ \\
\hline $\begin{array}{l}\text { 10 X 10 cm Round Individual } \\
\text { Fertilpot (Wood Fiber) }\end{array}$ & $\begin{array}{l}\text { Steam-Pressed Spruce Wood } \\
\text { Fiber }\end{array}$ & $\begin{array}{l}\text { Fertil SAS, Boulogne } \\
\text { Billancourt, France }\end{array}$ \\
\hline 4" Jiffy Pot (Peat) & Peat and Recycled Paper & $\begin{array}{l}\text { iffy Products of America } \\
\text { Inc., Lorain, OH }\end{array}$ \\
\hline $\begin{array}{l}\text { 4.5” NetPot (Slotted Rice } \\
\text { Hull) }\end{array}$ & Slotted Rice Hull & $\begin{array}{l}\text { Summit Plastic Company, } \\
\text { Akron, OH }\end{array}$ \\
\hline $\begin{array}{l}\text { 4.5" Standard Assembled } \\
\text { SoilWrap }{ }^{\circledR} \text { (PHA bioplastic) }\end{array}$ & $\begin{array}{l}\text { PHA (polyhydroxyalkanoate) } \\
\text { Bioplastic Sleeve }\end{array}$ & $\begin{array}{l}\text { Ball Horticultural Company, } \\
\text { West Chicago, IL }\end{array}$ \\
\hline n/a (Straw) & $\begin{array}{l}\text { 80:20 Rice Straw:Coconut } \\
\text { Fiber with Latex Binder }\end{array}$ & $\begin{array}{l}\text { Ivy Acres, Baiting Hollow, } \\
\text { NY }\end{array}$ \\
\hline
\end{tabular}


Table 3.2. Final plant growth of Lantana camara 'Luscious Citrus' and pot degradation of biopots after one growing season (15 weeks) in the landscape in 2011.

\begin{tabular}{|c|c|c|c|c|c|c|}
\hline Container Type & Fresh Wt. $(\mathrm{g})^{\mathrm{yz}}$ & Dry Wt. $(g)^{y z}$ & $\begin{array}{c}\text { Final Width } \\
(\mathrm{cm})^{\mathrm{yz}}\end{array}$ & $\begin{array}{c}\text { Final Height } \\
(\mathrm{cm})^{\mathrm{yz}}\end{array}$ & Plant Rating ${ }^{\mathrm{xz}}$ & $\%$ Degradation ${ }^{\mathrm{xz}}$ \\
\hline Coir & $354.8 \mathrm{a}$ & $97.1 \mathrm{a}$ & $93.7 \mathrm{a}$ & $39.6 \mathrm{a}$ & $1.9 \mathrm{a}$ & $3.9 \mathrm{~d}$ \\
\hline Manure & $310.3 \mathrm{a}$ & $90.5 \mathrm{a}$ & $99.5 \mathrm{a}$ & $39.6 \mathrm{a}$ & $2.8 \mathrm{a}$ & $83.7 \mathrm{a}$ \\
\hline Wood Fiber & $306.8 \mathrm{a}$ & 84.9 a & 88.2 a & $39.2 \mathrm{a}$ & $2.0 \mathrm{a}$ & $2.6 \mathrm{~d}$ \\
\hline Peat & $491.8 \mathrm{a}$ & $133.4 \mathrm{a}$ & $112.6 \mathrm{a}$ & $40.8 \mathrm{a}$ & $2.8 \mathrm{a}$ & $20.1 \mathrm{c}$ \\
\hline Slot. Rice & $493.6 \mathrm{a}$ & $138.5 \mathrm{a}$ & $105.9 \mathrm{a}$ & $42.1 \mathrm{a}$ & $2.8 \mathrm{a}$ & $23.5 \mathrm{c}$ \\
\hline PHA Biop. & $415.5 \mathrm{a}$ & $117.8 \mathrm{a}$ & $93.8 \mathrm{a}$ & $40.1 \mathrm{a}$ & $2.9 \mathrm{a}$ & $8.2 \mathrm{~cd}$ \\
\hline Straw & $376.5 \mathrm{a}$ & $103.4 \mathrm{a}$ & $99.5 \mathrm{a}$ & $39.0 \mathrm{a}$ & $2.3 \mathrm{a}$ & $44.1 \mathrm{~b}$ \\
\hline Plastic & 419.9 a & $117.0 \mathrm{a}$ & $100.5 \mathrm{a}$ & $38.8 \mathrm{a}$ & $2.0 \mathrm{a}$ &. \\
\hline$P$ value & 0.134 & 0.161 & 0.277 & 0.939 & 0.357 & $<0.001$ \\
\hline
\end{tabular}

Experimental units were replicated ten times. Statistical analysis using ANOVA with Holm-Sidak

method was used to indicate if treatments were different from other treatments (as indicated by lower case letters).

Percent degradation was determined by the dried weight of excavated pots after one growing season compared

to new dried pots never subjected to field exposure.

Missing data is represented by "."

All measurements were taken at the end of the experiment.

${ }^{\mathrm{z}}$ Means in a column followed by different letters are significantly different at the $P \leq 0.05$ level, Holm-Sidak method.

${ }^{\mathrm{y}}$ Data passed Normality Test (Shapiro Wilk) and Equal Variance Test.

${ }^{\mathrm{x}}$ Data passed Equal Variance Test, but failed Normality Test (Shapiro Wilk). 
Table 3.3. Final plant growth of Cleome hassleriana 'Seniorita Rosalita' and pot degradation of biopots after one growing season (15 weeks) in the landscape in 2011.

\begin{tabular}{|c|c|c|c|c|c|c|}
\hline Container Type & Fresh Wt. $(g)^{x z}$ & Dry Wt. (g) ${ }^{\mathrm{xz}}$ & $\begin{array}{c}\text { Final Width } \\
(\mathrm{cm})^{x z}\end{array}$ & $\begin{array}{c}\text { Final Height } \\
(\mathrm{cm})^{\mathrm{xz}}\end{array}$ & Plant Rating ${ }^{\mathrm{xz}}$ & $\%$ Degradation $^{\mathrm{yz}}$ \\
\hline Coir & $278.4 \mathrm{a}^{\mathrm{z}}$ & $73.4 \mathrm{a}$ & $56.2 \mathrm{a}$ & $83.0 \mathrm{a}$ & $5.0 \mathrm{a}$ & $9.8 \mathrm{~d}$ \\
\hline Manure & 300.8 a & $77.2 \mathrm{a}$ & $63.6 \mathrm{a}$ & $92.2 \mathrm{a}$ & $5.0 \mathrm{a}$ & $85.4 \mathrm{a}$ \\
\hline Wood Fiber & $286.1 \mathrm{a}$ & $69.9 \mathrm{a}$ & $60.2 \mathrm{a}$ & $89.5 \mathrm{a}$ & $5.0 \mathrm{a}$ & $7.2 \mathrm{~d}$ \\
\hline Peat & 299.7 a & $77.0 \mathrm{a}$ & $62.3 \mathrm{a}$ & 85.9 a & $5.0 \mathrm{a}$ & $31.2 \mathrm{c}$ \\
\hline Slot. Rice & 294.4 a & $79.4 \mathrm{a}$ & 58.5 a & 86.9 a & $5.0 \mathrm{a}$ & $18.0 \mathrm{~cd}$ \\
\hline PHA Biop. & $244.8 \mathrm{a}$ & $61.8 \mathrm{a}$ & $54.6 \mathrm{a}$ & $84.6 \mathrm{a}$ & $5.0 \mathrm{a}$ & $7.1 \mathrm{~d}$ \\
\hline Straw & $281.3 \mathrm{a}$ & $74.1 \mathrm{a}$ & $57.2 \mathrm{a}$ & $87.0 \mathrm{a}$ & $5.0 \mathrm{a}$ & $45.8 \mathrm{~b}$ \\
\hline Plastic & $361.1 \mathrm{a}$ & $93.3 \mathrm{a}$ & $62.8 \mathrm{a}$ & $90.9 \mathrm{a}$ & $5.0 \mathrm{a}$ & . \\
\hline$P$ value & 0.915 & 0.882 & 0.654 & 0.538 & 1 & $<0.001$ \\
\hline
\end{tabular}

Experimental units were replicated ten times. Statistical analysis using ANOVA with Holm-Sidak method was used to indicate if treatments were different from other treatments (as indicated by lower case letters). Percent degradation was determined by the dried weight of excavated pots after one growing season compared to new dried pots never subjected to field exposure.

Missing data is represented by "."

All measurements were taken at the end of the experiment.

${ }^{\mathrm{z}}$ Means in a column followed by different letters are significantly different at the $P \leq 0.05$ level, Holm-Sidak method.

${ }^{\mathrm{y}}$ Data passed Normality Test (Shapiro Wilk) and Equal Variance Test.

${ }^{\mathrm{x}}$ Data passed Equal Variance Test, but failed Normality Test (Shapiro Wilk). 
Table 3.4. Final plant growth of Impatiens spp. 'Sunpatiens Compact' and pot degradation of biopots after one growing season (15 weeks) in the landscape in 2011.

\begin{tabular}{|c|c|c|c|c|c|c|}
\hline Container Type & Fresh Wt. $(\mathrm{g})^{\mathrm{yz}}$ & Dry Wt. (g) ${ }^{\mathrm{yz}}$ & $\begin{array}{c}\text { Final Width } \\
(\mathrm{cm})^{\mathrm{yz}}\end{array}$ & $\begin{array}{c}\text { Final Height } \\
(\mathrm{cm})^{\mathrm{yz}}\end{array}$ & Plant Rating $^{\mathrm{yz}}$ & $\%$ Degradation $^{\mathrm{xz}}$ \\
\hline Coir & $233.2 \mathrm{a}^{\mathrm{z}}$ & $21.3 \mathrm{a}$ & $29.4 \mathrm{a}$ & $17.9 \mathrm{a}$ & $2.8 \mathrm{a}$ & $12.2 \mathrm{~cd}$ \\
\hline Manure & $183.9 \mathrm{a}$ & $17.7 \mathrm{a}$ & $28.2 \mathrm{a}$ & $36.0 \mathrm{a}$ & $2.4 \mathrm{a}$ & $69.8 \mathrm{a}$ \\
\hline Wood Fiber & $97.6 \mathrm{a}$ & $11.1 \mathrm{a}$ & $23.0 \mathrm{a}$ & $17.3 \mathrm{a}$ & $1.7 \mathrm{a}$ & $2.3 \mathrm{~d}$ \\
\hline Peat & $174.0 \mathrm{a}$ & $16.8 \mathrm{a}$ & $27.0 \mathrm{a}$ & $16.5 \mathrm{a}$ & $2.4 \mathrm{a}$ & $11.4 \mathrm{~cd}$ \\
\hline Slot. Rice & $416.9 \mathrm{a}$ & $34.2 \mathrm{a}$ & $38.0 \mathrm{a}$ & $20.3 \mathrm{a}$ & $0.1 \mathrm{a}$ & $20.0 \mathrm{c}$ \\
\hline PHA Biop. & $131.7 \mathrm{a}$ & $14.1 \mathrm{a}$ & $25.2 \mathrm{a}$ & $17.4 \mathrm{a}$ & $2.6 \mathrm{a}$ & $25.7 \mathrm{c}$ \\
\hline Straw & $239.0 \mathrm{a}$ & $24.8 \mathrm{a}$ & $31.8 \mathrm{a}$ & $21.0 \mathrm{a}$ & $2.5 \mathrm{a}$ & $43.4 \mathrm{~b}$ \\
\hline Plastic & 226.6 a & $20.4 \mathrm{a}$ & $29.7 \quad \mathrm{a}$ & $18.1 \mathrm{a}$ & $3.2 \mathrm{a}$ & \\
\hline $\mathrm{P}$ value & 0.501 & 0.505 & 0.624 & 0.585 & 0.276 & $<0.001$ \\
\hline
\end{tabular}

Experimental units were replicated ten times. Statistical analysis using ANOVA with Holm-Sidak method was used to indicate if treatments were different from other treatments (as indicated by lower case letters). Percent degradation was determined by the dried weight of excavated pots after one growing season compared to new dried pots never subjected to field exposure.

Missing data is represented by "."

All measurements were taken at the end of the experiment.

${ }^{\mathrm{z}}$ Means in a column followed by different letters are significantly different at the $P \leq 0.05$ level, Holm-Sidak method.

${ }^{\mathrm{y}}$ Data passed Normality Test (Shapiro Wilk) and Equal Variance Test.

${ }^{\mathrm{x}}$ Data passed Equal Variance Test, but failed Normality Test (Shapiro Wilk). 
Table 3.5. Final plant growth of Lantana camara 'Luscious Citrus' and pot degradation of biopots after one growing season (15 weeks) in the landscape in 2012.

\begin{tabular}{|c|c|c|c|c|c|c|}
\hline Container Type & Fresh Wt. $(\mathrm{g})^{\mathrm{vz}}$ & Dry Wt. $(g)^{y z}$ & $\begin{array}{c}\text { Final Width } \\
(\mathrm{cm})^{\mathrm{wz}}\end{array}$ & $\begin{array}{c}\text { Final Height } \\
(\mathrm{cm})^{\mathrm{wz}}\end{array}$ & Plant Rating ${ }^{\mathrm{yz}}$ & $\%$ Degradation $^{\mathrm{xz}}$ \\
\hline Coir & $225.8 \mathrm{a}^{\mathrm{z}}$ & $55.2 \mathrm{a}$ & $73.0 \mathrm{a}$ & $19.0 \mathrm{~b}$ & $5.0 \mathrm{a}$ & $6.0 \mathrm{c}$ \\
\hline Manure & 315.7 a & $74.4 \mathrm{a}$ & $79.8 \mathrm{a}$ & $16.1 \mathrm{~b}$ & $5.0 \mathrm{a}$ & $100.0 \mathrm{a}$ \\
\hline Wood Fiber & $286.2 \mathrm{a}$ & $68.3 \mathrm{a}$ & $80.0 \mathrm{a}$ & $17.9 \mathrm{~b}$ & $5.0 \mathrm{a}$ & $11.9 \mathrm{c}$ \\
\hline Peat & $319.0 \mathrm{a}$ & $76.6 \mathrm{a}$ & $75.9 \mathrm{a}$ & $18.0 \mathrm{~b}$ & $5.0 \mathrm{a}$ & $44.9 \mathrm{~b}$ \\
\hline Slot. Rice & $411.5 \mathrm{a}$ & $87.7 \mathrm{a}$ & $98.4 \mathrm{a}$ & $19.0 \mathrm{~b}$ & $5.0 \mathrm{a}$ & $9.3 \mathrm{c}$ \\
\hline PHA Biop. & $284.0 \mathrm{a}$ & $66.6 \mathrm{a}$ & $77.7 \mathrm{a}$ & $18.3 \mathrm{~b}$ & $5.0 \mathrm{a}$ & $64.1 \mathrm{~b}$ \\
\hline Straw & $235.0 \mathrm{a}$ & $55.0 \mathrm{a}$ & 70.9 a & $17.9 \mathrm{~b}$ & $5.0 \mathrm{a}$ & $56.8 \mathrm{~b}$ \\
\hline Plastic & $310.7 \quad \mathrm{a}$ & $76.6 \mathrm{a}$ & $80.6 \mathrm{a}$ & $25.4 \mathrm{a}$ & $5.0 \mathrm{a}$ & \\
\hline$P$ value & 0.083 & 0.072 & 0.092 & $<0.001$ & 1 & $<0.001$ \\
\hline
\end{tabular}

Experimental units were replicated ten times. Statistical analysis using ANOVA with Holm-Sidak method was used to indicate if treatments were different from other treatments (as indicated by lower case letters). Percent degradation was determined by the dried weight of excavated pots after one growing season compared to new dried pots never subjected to field exposure.

Missing data is represented by "."

All measurements were taken at the end of the experiment.

${ }^{\mathrm{z}}$ Means in a column followed by different letters are significantly different at the $P \leq 0.05$ level, Holm-Sidak method.

${ }^{\mathrm{y}}$ Data passed Normality Test (Shapiro Wilk) and Equal Variance test.

${ }^{\mathrm{x}}$ Data failed Normality Test (Shapiro-Wilk) and Equal Variance test.

${ }^{\mathrm{w}}$ Data passed Normality Test (Shapiro-Wilk), but failed Equal Variance test.

${ }^{\mathrm{v}}$ Data failed Normality Test (Shapiro-Wilk), but passed Equal Variance test. 
Table 3.6. Final plant growth of Cleome hassleriana 'Seniorita Rosalita' and pot degradation of biopots after one growing season (15 weeks) in the landscape in 2012.

\begin{tabular}{|c|c|c|c|c|c|c|}
\hline Container Type & Fresh Wt. $(\mathrm{g})^{\mathrm{vZ}}$ & Dry Wt. $(g)^{\mathrm{wZ}}$ & $\begin{array}{c}\text { Final Width } \\
(\mathrm{cm})^{\mathrm{yz}}\end{array}$ & $\begin{array}{c}\text { Final Height } \\
(\mathrm{cm})^{\mathrm{yz}}\end{array}$ & Plant Rating $^{\mathrm{vz}}$ & $\%$ Degradation $^{\mathrm{xz}}$ \\
\hline Coir & $192.7 \mathrm{a}^{\mathrm{z}}$ & $50.2 \mathrm{a}$ & $44.7 \mathrm{~b}$ & $74.5 \mathrm{a}$ & $5.0 \mathrm{a}$ & $13.6 \mathrm{~d}$ \\
\hline Manure & $301.2 \mathrm{a}$ & 77.9 a & $50.9 \mathrm{ab}$ & $75.1 \mathrm{a}$ & $5.0 \mathrm{a}$ & $95.9 \mathrm{a}$ \\
\hline Wood Fiber & $285.2 \mathrm{a}$ & $74.7 \mathrm{a}$ & $58.9 \mathrm{ab}$ & $74.1 \mathrm{a}$ & $5.0 \mathrm{a}$ & $3.2 \mathrm{~d}$ \\
\hline Peat & $354.4 \mathrm{a}$ & $87.7 \mathrm{a}$ & $53.5 \mathrm{ab}$ & $75.4 \mathrm{a}$ & $5.0 \mathrm{a}$ & $32.6 \mathrm{c}$ \\
\hline Slot. Rice & $362.0 \mathrm{a}$ & 88.2 a & $63.6 \mathrm{a}$ & $79.5 \mathrm{a}$ & $5.0 \mathrm{a}$ & $3.6 \mathrm{~d}$ \\
\hline PHA Biop. & $186.1 \mathrm{a}$ & $49.2 \mathrm{a}$ & $48.8 \mathrm{ab}$ & 74.5 a & $5.0 \mathrm{a}$ & $40.2 \mathrm{c}$ \\
\hline Straw & $244.7 \mathrm{a}$ & $60.5 \mathrm{a}$ & $49.6 \mathrm{ab}$ & $74.6 \mathrm{a}$ & $5.0 \mathrm{a}$ & $52.8 \mathrm{~b}$ \\
\hline Plastic & $235.3 \mathrm{a}$ & $58.2 \mathrm{a}$ & $50.6 \mathrm{ab}$ & $70.5 \mathrm{a}$ & $5.0 \mathrm{a}$ & \\
\hline$P$ value & 0.042 & 0.055 & 0.025 & 0.445 & 1 & $<0.001$ \\
\hline
\end{tabular}

Experimental units were replicated ten times. Statistical analysis using ANOVA with Holm-Sidak method was used to indicate if treatments were different from other treatments (as indicated by lower case letters). Percent degradation was determined by the dried weight of excavated pots after one growing season compared to new dried pots never subjected to field exposure.

Missing data is represented by "."

All measurements were taken at the end of the experiment.

${ }^{\mathrm{z}}$ Means in a column followed by different letters are significantly different at the $P \leq 0.05$ level, Holm-Sidak method.

${ }^{\mathrm{y}}$ Data passed Normality Test (Shapiro Wilk) and Equal Variance test.

${ }^{\mathrm{x}}$ Data failed Normality Test (Shapiro-Wilk) and Equal Variance test.

${ }^{\mathrm{w}}$ Data passed Normality Test (Shapiro-Wilk), but failed Equal Variance test.

${ }^{\mathrm{v}}$ Data failed Normality Test (Shapiro-Wilk), but passed Equal Variance test. 
Table 3.7. Final plant growth of Impatiens spp. 'Sunpatiens Compact' and pot degradation of biopots after one growing season (15 weeks) in the landscape in 2012.

\begin{tabular}{|c|c|c|c|c|c|c|}
\hline Container Type & $\begin{array}{c}\text { Fresh Wt. } \\
(\mathrm{g})^{\mathrm{Wz}}\end{array}$ & Dry Wt. $(g)^{\mathrm{wZ}}$ & $\begin{array}{c}\text { Final Width } \\
(\mathrm{cm})^{\mathrm{wz}}\end{array}$ & $\begin{array}{c}\text { Final Height } \\
(\mathrm{cm})^{\mathrm{wz}}\end{array}$ & Plant Rating ${ }^{\mathrm{vz}}$ & $\%$ Degradation $^{\mathrm{xz}}$ \\
\hline Coir & $1577.8 \mathrm{a}^{\mathrm{z}}$ & $109.5 \mathrm{a}$ & $73.9 \mathrm{a}$ & $37.1 \mathrm{a}$ & $5.0 \mathrm{a}$ & $6.0 \mathrm{~d}$ \\
\hline Manure & $1638.0 \mathrm{a}$ & $109.6 \mathrm{a}$ & $77.3 \mathrm{a}$ & $38.0 \mathrm{a}$ & $5.0 \mathrm{a}$ & 98.9 a \\
\hline Wood Fiber & $1745.2 \mathrm{a}$ & $122.3 \mathrm{a}$ & $76.7 \mathrm{a}$ & $38.0 \mathrm{a}$ & $5.0 \mathrm{a}$ & $30.4 \mathrm{bc}$ \\
\hline Peat & $782.2 \mathrm{~b}$ & $59.3 \mathrm{~b}$ & $56.1 \mathrm{~b}$ & $33.6 \mathrm{a}$ & $5.0 \mathrm{a}$ & $47.0 \mathrm{~b}$ \\
\hline Slot. Rice & $1377.5 \mathrm{a}$ & $104.5 \mathrm{a}$ & $73.4 \mathrm{a}$ & $33.8 \mathrm{a}$ & $5.0 \mathrm{a}$ & $16.8 \mathrm{~cd}$ \\
\hline PHA Biop. & $1406.8 \mathrm{a}$ & $98.5 \mathrm{a}$ & $72.6 \mathrm{a}$ & $34.9 \mathrm{a}$ & $5.0 \mathrm{a}$ & $32.0 \mathrm{bc}$ \\
\hline Straw & $1374.8 \mathrm{a}$ & $98.3 \mathrm{a}$ & $72.8 \mathrm{a}$ & $36.8 \mathrm{a}$ & $5.0 \mathrm{a}$ & $48.7 \mathrm{~b}$ \\
\hline Plastic & $1670.7 \mathrm{a}$ & $115.7 \mathrm{a}$ & $73.3 \mathrm{a}$ & $38.0 \mathrm{a}$ & $5.0 \mathrm{a}$ & \\
\hline$P$ value & $<0.001$ & $<0.001$ & 0.002 & 0.434 & 1 & $<0.001$ \\
\hline
\end{tabular}

Experimental units were replicated ten times. Statistical analysis using ANOVA with Holm-Sidak method was used to indicate if treatments were different from other treatments (as indicated by lower case letters). Percent degradation was determined by the dried weight of excavated pots after one growing season compared to new dried pots never subjected to field exposure.

Missing data is represented by "."

All measurements were taken at the end of the experiment.

${ }^{\mathrm{z}}$ Means in a column followed by different letters are significantly different at the $P \leq 0.05$ level, Holm-Sidak method.

${ }^{\mathrm{y}}$ Data passed Normality Test (Shapiro Wilk) and Equal Variance test.

${ }^{\mathrm{x}}$ Data failed Normality Test (Shapiro-Wilk) and Equal Variance test.

${ }^{\mathrm{w}}$ Data passed Normality Test (Shapiro-Wilk), but failed Equal Variance test.

${ }^{\mathrm{v}}$ Data failed Normality Test (Shapiro-Wilk), but passed Equal Variance test. 


\section{Addendum: Evaluating the Denesting Times of Biodegradable Pots}

Biodegradable plant pots are being evaluated for their potential to replace traditional plastic pots in the horticulture industry. Past research has explored the marketability, consumer preference, and growth of plants in biodegradable pots in a greenhouse setting (Hall, 2010; Evans and Hensley, 2004). This research explored the incidence of algal/fungal growth during greenhouse production, plant growth in a landscape setting, water use, as well as the pot strength of biodegradable pots in the pre and post planting environment. These factors will likely all play a contributing role in a grower's willingness to use biodegradable pots for future production.

Cost will also likely play an important role in the decision making of both the producer and the consumer. Upfront costs, such as the price of the pot, and potential markup to the consumer, may impact sales. However, other indirect costs may play an even greater role. Little is known about the ease of handling of the biodegradable pots in modern day greenhouse settings. In a large production, any hindrances to efficient production could be very costly to a grower.

Throughout our research, we noticed that the denesting time of some pots (the time it takes to pull the pots apart), was greater for some pots than others. The work presented here evaluated the time required to denest nine types of biodegradable pots.

\section{Materials and Methods}

\section{Pots}

Nine types of biopots were evaluated for their required denesting time compared to a control plastic pot (Figure 2.1). These pots were either purchased or accepted as donations from their respective manufacturers (Table 4.1). Pot materials ranged included coir (Coir), composted manure fiber (Cowpot), spruce wood fiber (Fertil), peat (Jiffy), rice hulls (Slotted and Solid Rice 
Pot), rice straw (Straw), and bioplastic pots made from polylactic acid (PLA) (TerraShell) and polyhydroxyalkanoate (PHA) sleeve (Soilwrap). Pots will hereafter be referred to by their material composition.

\section{Experimental Design}

Sixteen West Virginia University students were recruited for this study, and asked to work in pairs. Each pair of students was given two trays with the capacity to hold twelve pots each, and a stack of 24 tightly nested pots. One student was responsible for the denesting of the pots and the placing of them into trays. This was to simulate a typical greenhouse worker. The second student was responsible for timing the denesting process using a stopwatch, and recording the time into a chart provided. Students were also asked to record any thoughts they had on particular pots and the process of denesting.

Students were instructed to be precise, and to move quickly, but consistently. Once the time was recorded for each stack of pots, students were instructed to carefully collect the pots, and renest them back together the same way that they received them. Pots were rotated among students until each group had denested all types of pots one time, resulting in eight replications.

\section{$\underline{\text { Results and Discussion }}$}

Significant differences $(P<0.001)$ were observed in the required denesting time between pot types (Table 1.25). Particularly, the peat pot required on average more time to denest than all other pots. Participants in the study needed 126.4 seconds to denest 24 pots, or roughly 5.3 seconds per pot. In comparison, participants needed only 21.9 seconds to denest 24 Straw pots, or less than 1 second per pot. The plastic control pot required 28.4 seconds, resulting in 1.2 seconds per pot. Of the ten pots tested, only peat, manure, and wood fiber pots had denesting times significantly different than that of the plastic pot. 
The ease of pot denesting and the required time to do so most certainly will have an impact on a grower's decision to use biodegradable pots in a production facility. The time required to denest peat pots was over five times greater than the time required to denest the same amount of slotted rice hull pots.

Previous studies have focused on the compatibility of the biodegradable pots in commercial facilities with mechanized equipment. Koeser et al., (2013), looked at the mechanical filling of biodegradable pots using a gravity fed pot filling machine. The study found that after calibrating the machine for the desired height and width of the pot, the proportion of successfully filled pots was not significantly different among pot type. However, the study did find a significant difference in pot filling speed between container types. Specifically, peat, manure, and straw containers required substantially more time to fill than all other pots (Koeser et al., 2013). The author noted that conveyor belt speed was most affected by the rate at which the pots were unstacked (denested) and loaded into shuttle trays by employees. This observation corroborated our results and indicates that denesting time may have a significant impact on the potential adoption of biopots in the greenhouse industry.

\section{Conclusion}

Undoubtedly, the time required to denest some biodegradable containers could be very costly to a grower in terms of not only labor required, but could also result in a production loss if the denesting of pots causes delays. It is uncertain whether over time, employees could possibly adapt methods and tools to expedite denesting process of certain containers. Additional research is needed to explore the depth of this concern, and to quantify the costs of additional denesting time requirements. 
Table 4.1 . Average denesting time required for biodegradable pots.

\begin{tabular}{lc}
\hline Container Type & Denesting Time (Seconds) ${ }^{\mathrm{xz}}$ \\
\hline Coir & $39.2 \mathrm{bcd}$ \\
Manure & $70.6 \mathrm{~b}$ \\
Wood Fiber & $65.2 \mathrm{bc}$ \\
Peat & $126.4 \mathrm{a}$ \\
Slot. Rice Hull & $21.9 \mathrm{~d}$ \\
PLA Bioplastic & $27.0 \mathrm{~cd}$ \\
PHA Bioplastic & $30.4 \mathrm{bcd}$ \\
Solid Rice Hull & $22.9 \mathrm{~d}$ \\
Straw & $59.1 \mathrm{bcd}$ \\
\hline Plastic & $28.4 \mathrm{~cd}$ \\
& \\
P value & $<0.001$ \\
\hline
\end{tabular}

Experimental units were replicated eight times. Statistical analysis using ANOVA with Holm-Sidak

method was used to indicate if treatments were different from other treatments (as indicated by lower case letters).

Values reflect time required to denest 24 tightly nested pots and place into a shuttle tray.

${ }^{\mathrm{z}}$ Means in a column followed by different letters are significantly different at the $\mathrm{P} \leq 0.05$ level, Holm-Sidak

${ }^{\mathrm{x}}$ Data failed Normality test (Shapiro Wilk) and Equal Variance Test. 


\section{Bibliography:}

Appleton, B. L. 1989. Evaluation of nursery container designs for minimization or prevention of root circling. J. of Environ. Hort. 7(2):59-61.

Ball, V. 1998. Ball Redbook. Ball Publishing. Batavia, Il. Pages 576-582.

Beeson, R.C.J., J.R. Harris, J. Lea-Cox, H.M. Mathers, P.J. Klinger, H.M. Gramling, T.E. Bilderback, M.A. Arnold, S. Chandler, and B. Bolusky. 2004. Strategic vision of container nursery irrigation in the next ten years. J. Environ. Horticulture 22(2):113115.

Beeson, R.C.J. 2006. Relationship of plant growth and actual evapotranspiration to irrigation frequency based on management allowed deficits for container nursery stock. J. Am. Soc. Hort. Sci. 131(1):140-148.

Belliveau, D. 2009. Plastics... and Beyond. 27 October 2011. http://gpnmag.com/articles/plasticsandbeyond.pdf

Bohmont, B. 1983. The New Pesticide User's Guide. Reston, VA. Reston Publishing Co.

Carson, R. 1962. Silent Spring. Boston, MA. Houghton Mifflin Company. Pages 15-23

Casida, J.E., and G.B. Quistand. 1998. Golden age of insecticide research: Past, present, or future? Annu. Rev. of Entomol. 43:1-16.

Cavins, T., B. Whipker, and W. Fonteno. 2005. Pourthru: A method for monitoring nutrition in the greenhouse. Acta Hort. 779:289-298.

Chappell, M. 2012. Alternatives to petroleum-based containers for the nursery industry. The University of Georiga Cooperative Extension. B 1407.

CowPots. 2010. Why Are Cowpots Better? 27 October 2011. http://www.cowpots.com/cowpotsbetter.html

Davidson, H., R. Mecklenburg, and C. Peterson. 2000. Nursery Management. Fourth Edition. Upper Saddle River, NJ. Prentice Hall.

Delaplane, K.S. 1996. Pesticide usage in the United States: History, benefits, risks, and trends. North Carolina State University Cooperative Extension Service Factsheet http://ipm.ncsu.edu/safety/factsheets/pestuse.pdf

Dole, J. and Wilkins, H. 2005. Floriculture Principles and Species. Pearson Education, Inc. Upper Saddle River, NJ. 
EPA. 2010. Municipal solid waste generation, recyling, and disposal in the United States: Facts and Figures for 2009. www.epa.gov/wastes

Evans, M.R., and Hensley, D.L. 2004. Plant growth in plastic, peat, and processed poultry feather fiber growing containers. Hort Science, 39(5): 1012-1014.

Evans, M. R., and D. Karcher. 2004. Properties of plastic, peat, and processed poultry feather fiber growing containers. Hort Science. 39(5): 1008-1011.

Evans, M. R., J. Kuehny, and M. Taylor. 2010. Physical properties of biocontainers for greenhouse crops production. HortTech. 20(3): 549-555.

Fereres, E., D. Goldhamer, and L. Parsons. 2003. Irrigation water management of horticultural crops. HortScience. 38(5): 1036-1042.

Fertil. 2011. What is Fertilpot? 27 October 2011. http://fertil.us/fpwhatis.htm

Garthe, J.W. and P.D. Kowal. 1993. Recyling used agricultural plastics. PennState fact sheet C-8. 21 Aug. 2008. http://www.abe.psu.edu/extension/factsheets/c/C8.pdf

Goulding, K., Jarvis, S. and A. Whitmore. 2008. Optimizing nutrient management for farm systems. Philos. T. Roy. Soc. B 363: 667-680.

Hall, C. R., R.G. Lopez, J.H. Dennis, C. Yue, B.L. Campbell, and B.K. Behe. 2010. The appeal of biodegradable packaging to floral consumers. HortScience. 45(4): 583-591.

Hanks, M. 1995. A Grower's Guide to Flowering Plants and Shrubs. Random House Value Publishing, Inc. New York, NY. Page 69.

Higginbotham, J.A. 1990. Four centuries of planting and progress: A history of the US nursery industry. Am. Nurseryman. 171(12). Special Historical Issue.

Ignacimuthu, S., and S. Jayaraj. 2005. Sustainable Insect Pest Management. New Delhi. Narosa Publishing House. Pp. 19-25

Janick, J. 2007. The origins of horticultural technology and science. Acta Horticulture, 759: 41- 50.

Koeser, A. 2013. Dissertation: Performance and environmental impacts of biocontainers in horticultural crop production systems. http://hdl.handle.net/2142/44332

Koeser, A., G. Kling, C. Miller, and D. Warnock. 2013a. Compatibility of biocontainers in commercial greenhouse crop production. HortTechnology. 23(2): 149-156. 
Koeser, A., S. Lovell, M. Evans, and J. Stewart. 2013b. Biocontainer water use in short-term greenhouse crop production. HortTechnology. 23(2):215-219.

Kuehny, J., M. Taylor, and M. Evans. 2011. Greenhouse and landscape performance of bedding plants in biocontainers. HortTechnology. 21(2):155-161.

McNeill, J.R., and V.V. Winiwarter. 2004. Breaking the sod: Humankind, history, and soil. Science. 304(5677):1627-1629.

McWilliams, J.E. 2008. “The horizon opened up very greatly": Leland O. Howard and the transition to chemical insecticides in the United States, 1894-1927. Agric. Hist. 82(4):468-495.

Mikkelsen, R. and T. Bruulsema. 2005. Fertilizer use for horticultural crops in the U.S. during the $20^{\text {th }}$ century. HortTech. 15(1):24-30.

Mohan, A. 2010. Plantable nursery pot biodegrades in soil. 27 October 2011. www.greenerpackage.com.

Mullen, J. D., J. Alston, D. Sumner, M. Kreith, and N. Kuminoff. 2005. The payoff to public investments in pest-management $\mathrm{R}$ and D: General issues and a case study emphasizing integrated pest management in California. Rev. Agr. Econ. 27(4):558-573.

Nambuthiri, S., R. Schnelle, A. Fulcher, R. Geneve, A. Koeser, S. Verlinden, and R. Conneway. 2013. Alternative containers for a sustainable greenhouse and nursery crop production. UK Cooperative Extension Service. HortFact-6000.

National Research Council.Committee on the Future Role of Pesticides in US Agriculture. 2000. The future role of pesticides in US agriculture._Washington, DC. National Academy Press. Pages 17-27

Nelson, P. 2002. Greenhouse Operation and Management. $6^{\text {th }}$ Edition. Prentice Hall. Upper Saddle River, NJ.

NOAA National Climatic Data Center. 2012. State of the climate: National overview for July 2012. Published online August 2012, retrieved on October 22, 2013. http://www.ncdc.noaa.gov/sotc/national/2012/7

Poincelot, R. P. 2004. Sustainable Horticulture. Upper Saddle River, NJ. Prentice Hall. Pp. 15, $212,362,476$.

Simmons, J.S. 1945. How magic is DDT? Saturday Evening Post. Vol. 217 Issue 28, p18-86.

Spiertz, J.H.J. 2008. Nitrogen, sustainable agriculture and food security. Agron. for sustain. dev. 30(1):43-55. 
Stern V.M., R.F. Smith, R. van den Bosch, and K.S. Hagen. 1959. The integrated control concept. Hilgardia. 29:81-101.

Taylor, M., M. Evans, and J. Kuehny. 2010. The beef on biocontainers: Strength, water use, biodegradability and greenhouse performance. OFA Bulletin. Number 923.

Tejano, E.A. 1985. State of the art of coconut coir dust and husk utilization. The Philippine Journal of Coconut Studies. 1:1-7.

Van de Wetering, P. 2008. Straw pots. Greenhouse Product News. Volume 18. Number 4. www. Gpnmag.com

Veith T.L. 2002. Agricultural BMP placement for cost-effective pollution control at the watershed level. PhD Dissertation, Virginia Polytechnic Institute and State University, Blacksburg, VA.

Verlinden, Sven. November 2011. Personal Communication.

Warsaw, A.L., J.A. Andresen, B.M. Cregg, and R.T. Fernandez. 2009. Water conservation, growth, and water use efficiency of container-grown woody ornamentals irrigated based on daily water use. HortScience. 44(5):1308-1318

Yue, C., C. Hall, B. Behe, B. Campbell, J. Dennis and R. Lopez. 2010. Are consumers willing to pay more for biodegradable containers than for plastic ones? Evidence from hypothetical conjoint analysis and nonhypothetical experimental auctions. J. Agr. Ap. Econ. 42(4):757-772. 